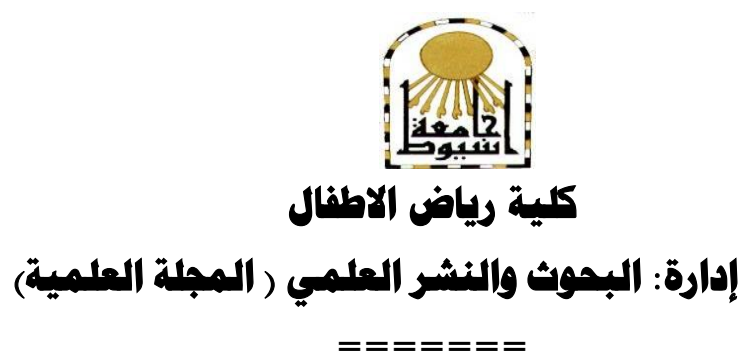

\title{
برناميج تدريبي لتنمية المهارات الناعمة لمعلمات رياض الأطفال
}

$$
\text { إعــــداد }
$$

أ.م.د/ سعيد عبد المعزظ على هوسي

$$
\text { كلية التربية - جاذعاذ الطفل المساعد حلوان }
$$

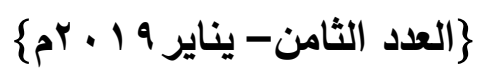




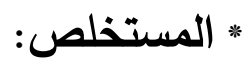

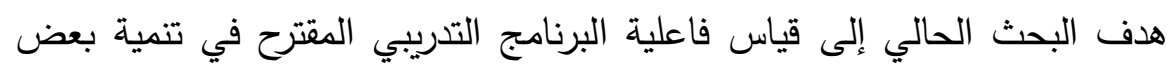

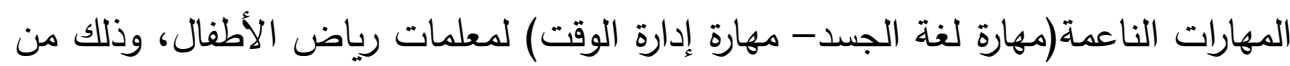
خلال الإجابة عن الأسئلة الآتية: 1- ما المهارات الناعمة المناسبة لمعلمات رياض الأطفال؟ r - ما أهم المهارات الناعمة لمعلمات رياض الأطفال من وجهة نظرهن؟ r- ما فاعلية البرنامج التدريبي المقترح في تتمية بعض المهارات الناعمة(مهارة لغة الجسد-

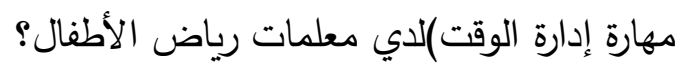

تكونت عينة البحث من عينة عشوائية من معلمات الروضة يبلغ عددها .ـ ؛

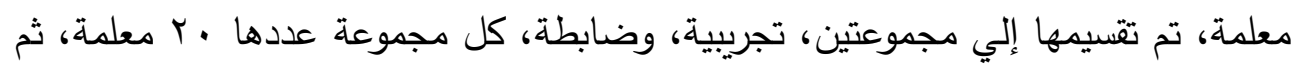
تم تطبيق أداتي البحث- بطاقة الملاحظة، والأختبار التحصيلي- عليهن قبليا. وتم تتفيذ البرنامج التدريبي وفقاً للجدول الزمنى الموضوع مسبقاً، وبعد الإنتهاء من تتفيذ تجربة البحث، تم تطبيق أداتي البحث- بطاقة الملاحظة، والأختبار التحصيلي - بعدياً

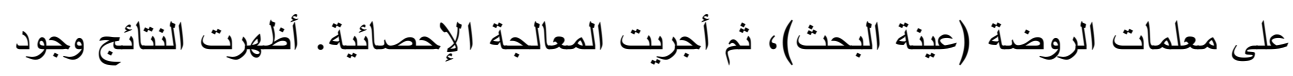

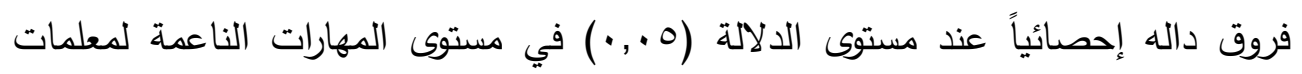
الروضة لصالح المجموعة التجريبية، مما يشير إلى فاعلية البرنامج التدريبي في تتمية بعض المهارات الناعمة(مهارة لغة الجسد- مهارة إدارة الوقت) لمعلمات الروضئة. (الكلمات المفتاحية : المهارات الناعمة، معلمات رياض الأطفال، البرامج التدريبية) 


\title{
| (أ.مدـ/ سعبد عبد المعز على موسي
}

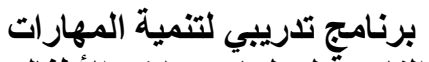

الناعمة لمعلمات رياض لترية الأطفار

\section{Training Program to Develop Soft Skills of Kindergarten Teachers}

\begin{abstract}
:
The present study aimed at measuring the effectiveness of the proposed training program in developing some soft skills (body language skill- time management skill) of kindergarten teachers by answering the following questions:
\end{abstract}

1- What are the soft skills that fit kindergarten teachers?

2- What are the most important soft skills for kindergarten teachers from their point of view?

3- What is the effectiveness of the proposed training program in the development of some soft skills (body language skill - time management skill) for kindergarten teachers?

The study included a random sample of 40 kindergarten teachers, which were divided into two groups, experimental group and control group. Each group had 20 teachers. The research tools, observation card \& achievement test, were applied to them as a preapplication.

The training program was implemented in accordance with the pre-set timetable. After the completion of the research experiment, the research tools, observation card \& achievement test, were applied to the research sample of kindergarten teachers as a post-application. Statistical analysis was performed and the results showed statistically
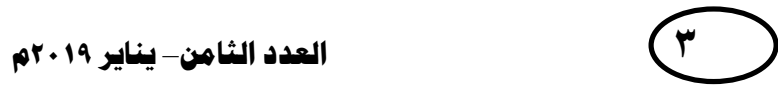
significant differences at the level of (0.05) with regard to the level of soft skills of kindergarten teachers in favor of the experimental group, which indicates the effectiveness of the training program in the development of some soft skills (body language skill, time management skill) for kindergarten teachers.

(Keywords: soft skills, kindergarten teachers, training programs). 


\section{مقدمه:}

أي مجتمع إن أراد الاخول في حلبة المنافسة الدولية، أن يسعي بكل السبل للعناية

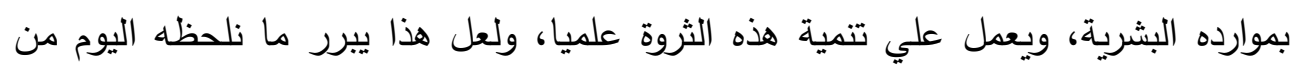

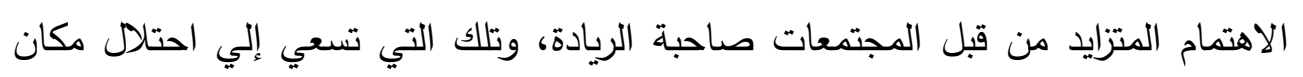
لائق في عالم المستقبل، بالاستثمار الضخم في التعليم والتدريب، وفي التتمية البشرية،

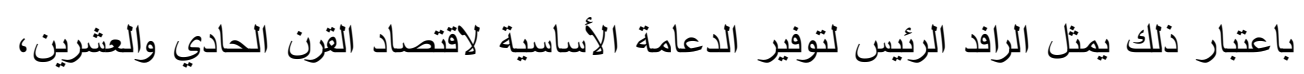

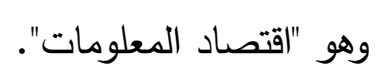

والمعلم إحدي الدعامات الرئيسية التي يعتمد عليها النظام التعليمي في تحقيق

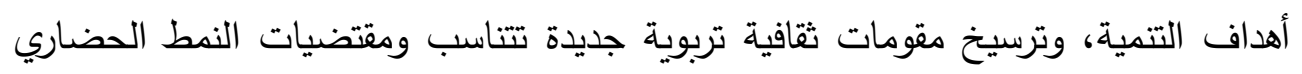

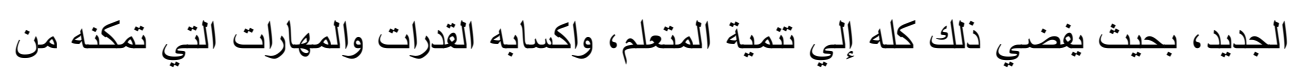
التعايش الآمن مع ما تفرضاه هذه الصيغة الحضارية من تحديات. ونجاح المعلم في القيام بأدواره الجديدة المتوقعة، يستلزم امتلاكه جملة من المهارات

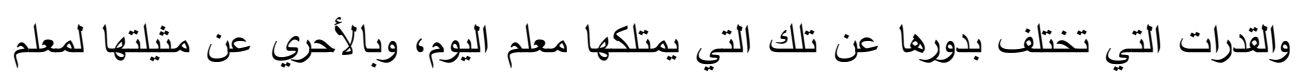

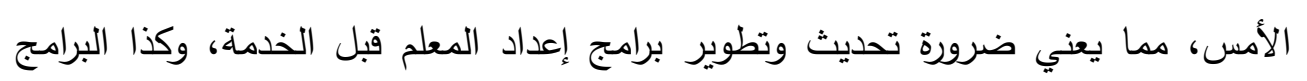

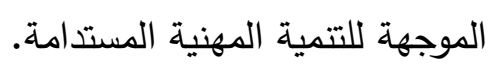

ولذلك ظهرت التتمية المهنية المستدامة التي تعد مدخلا مهما وأساسيا من مدخلات

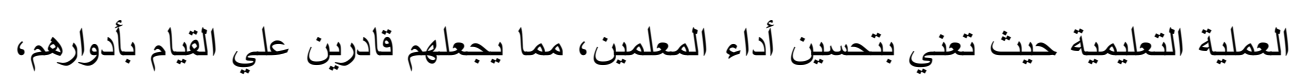

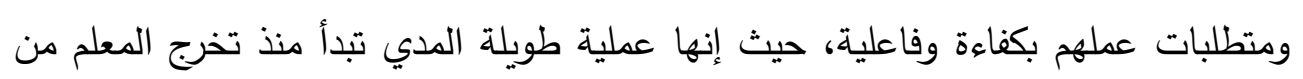

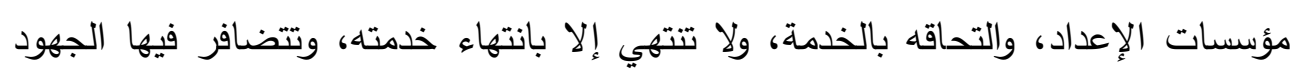

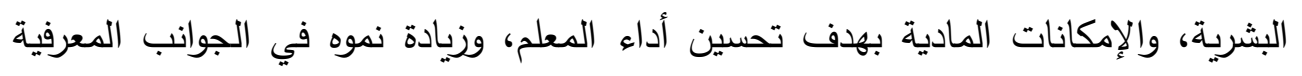

$$
\text { والمهارية والوجدانية(بيومي ضحاوي، وسلامة حسين، } 9 \text {. . ؟، ج). }
$$

وتزداد الحاجة إلى الاهتمام بتدريب المعلم تدريباً جيداً في ضوء الأدوار الحديثة

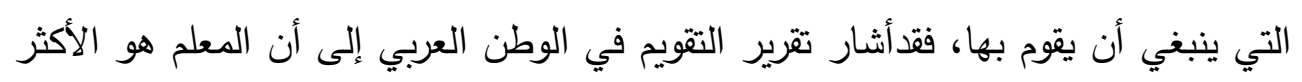

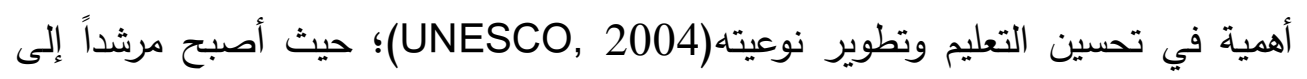


مصادر المعرفة، ومنسقاً لعمليات التعليم، ومقوماً لنتائج التعّلم، وموجهاً للمتعلم في ضوء ما يتناسب مع قدراته وميوله.

وعندما ينتقل الشخص من مرحلة التعليم إلى سوق العمل، يشعر أن هناك اختلاف

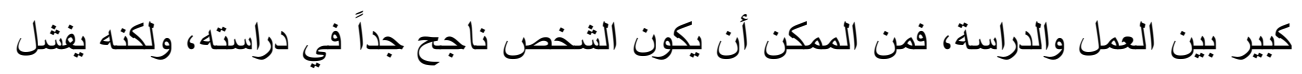

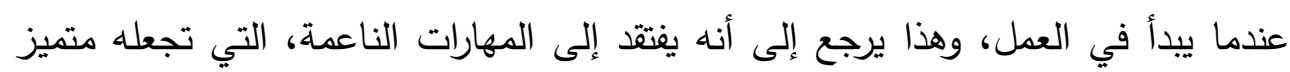
عن غيره، فكل منا لديه القدرة على حفظ المعلومات، وتحقيق النجاح في الدراسة، ولكن إنه القليل منا من يستطيع أن ينجح في سوق العمل.

وكلا من المهارات الناعمة والصلبة مهمة عند التقدم بطلب لوظيفة معلم أو معلمة،

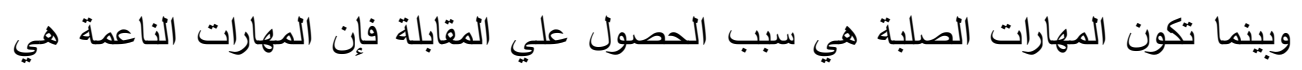
السبب في الحصول علي الوظيفة، لأن أصحاب ومديري المدارس يبحثون عن الأشخاص

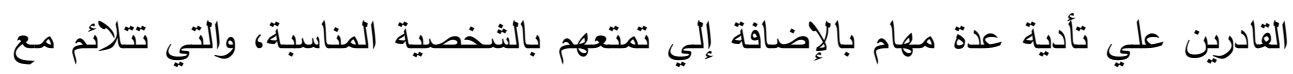
المؤسسة التعليمية، وتعطي انطباع جيد عنها لأولياء الأمور (Investopedia 2014,2). وأظهرت العديد من الدراسات مدي أهمية المهارات الناعمة لدي أرباب العمل عند

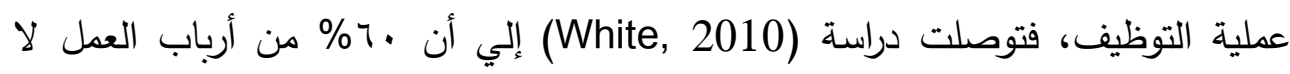
يقومون بتوظيف خريجي الجامعات، وأغلب المتقدمين للوظائف، نظرا لافتقارهم إلي

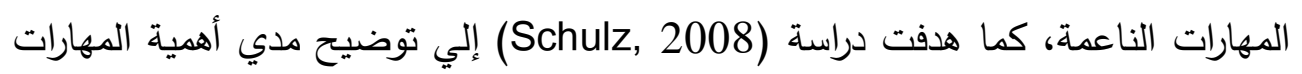
الناعمة في حياة الطلبة الجامعية، وما بعد الجامعية، وناقشت الدراسة كيف أن المهارات

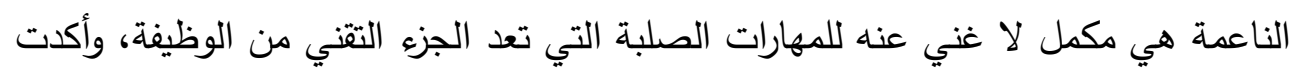

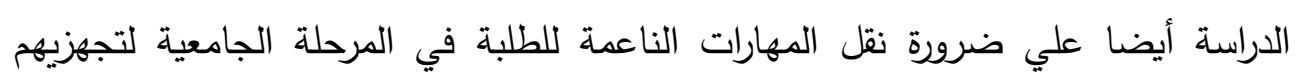
لسوق العمل بشكل أفضل.

ومعلمة الروضة يجب أن يكون لديها مهارات تمكنها من أداء دورها الحيوي والفعال

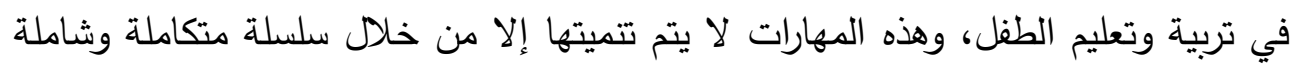

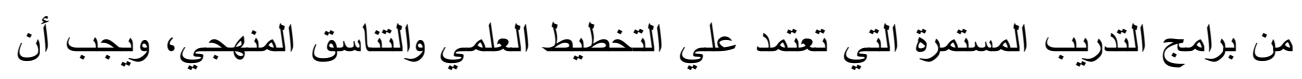
ترتبط هذه البرامج بالمشكلات اليومية التي تواجهها المعلمة في عملها إضافة إلي استثمارها 
للمستجدات في جوانب عملية التعليم والتعلم في ضوه معايير توجه ممارستها التربوية داخل رياض الأطفال وتعمل علي تحسين هذه الممارسات بشكل مستمر .

وبعد الاطلاع على محاور الوثيقة القومية الأكاديمية القياسية لقطاع كليات رياض

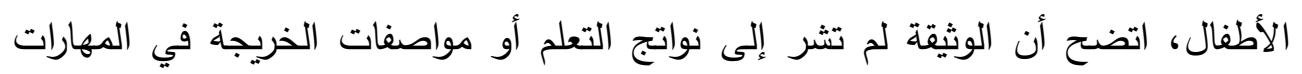

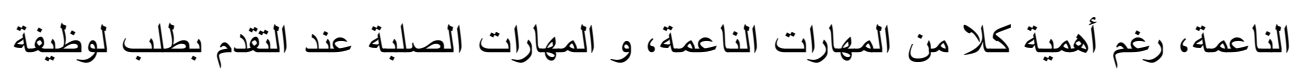

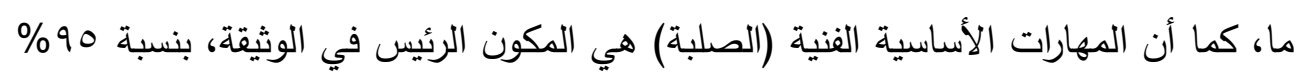

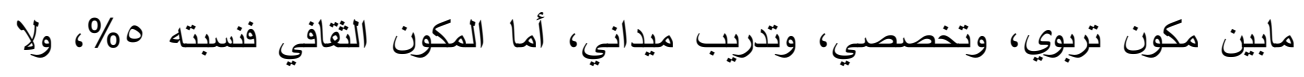

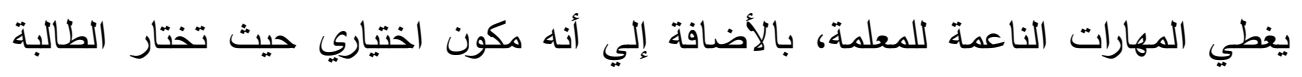

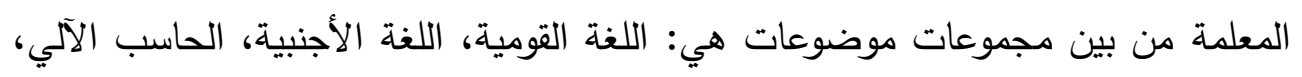

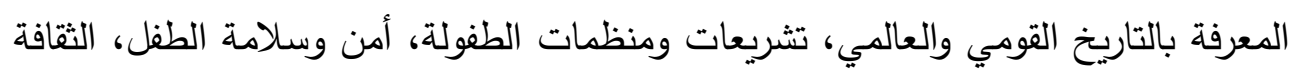

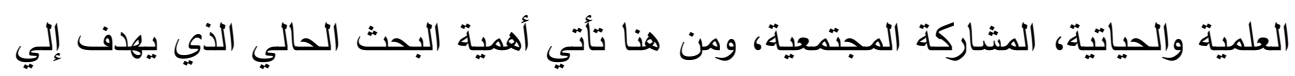

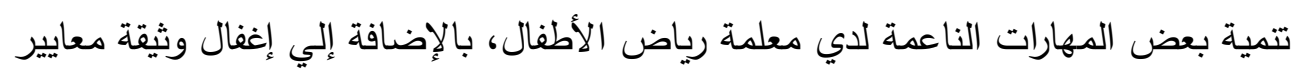
إعداد معلمة الروضة للمهارات الناعمة.

فقد لاحظ الباحث خلا فترة الإشراف على التدريب الميدانى عدم تمكن الطالبات/

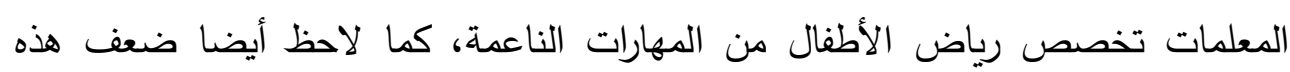
المهارات لدي معلمات الروضة في بعض الروضات بإدارة القاهرة الجديدة التعليمية

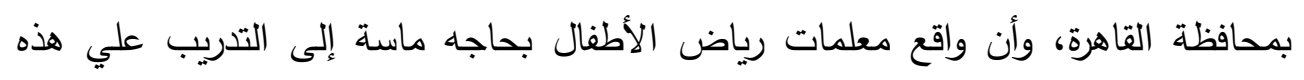
المهارات.

\section{مشكلة البحث:}

في ضوء ما سبق عرضه تتضح مشكلة البحث على النحو التالي: انخفاض مستوي المهارات الناعمة(مهارة لغة الجسد- مهارة إدارة الوقت) لدي معلمات الروضة، مما يسبب مشكلات خلال مزاولتهن للعمل المهنى فى مجال التخصص. 
1- ما المهارات الناعمة المناسبة لمعلمات رياض الأطفال؟

ץ - ما أهم المهارات الناعمة لمعلمات رياض الأطفال من وجهة نظرهن؟

r- ما فاعلية البرنامج التدريبي المقترح في تتمية بعض المهارات الناعمة(مهارة لغة الجسد-

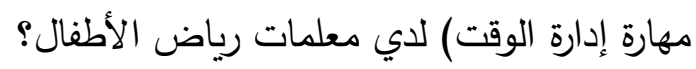

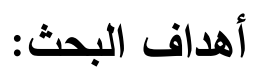

1- تحديد المهارات الناعمة المناسبة لمعلمات رياض الأطفال.

r - تحديد أهم المهارات الناعمة من وجهة نظر معلمات رياض الأطفال.

r- قياس فاعلية البرنامج التدريبي في تتمية بعض المهارات الناعمة(مهارة لغة الجسد-

مهارة إدارة الوقت) لدي معلمات رياض الأطفال.

أهمية البحث: قد يفيد هذا البحث في:

1 - تحديد نقاط القوة والضعف في الأداء المهني لمعلمات رياض الأطفال (عينة البحث).

r - تتمية بعض المهارات الناعمة(مهارة لغة الجسد- مهارة إدارة الوقت) لمعلمات

رياض الأطفال(عينة البحث).

r- قياس مستوي بعض المهارات الناعمة(مهارة لغة الجسد- مهارة إدارة الوقت) لدي

معلمات رياض الأطفال(عينة البحث).

\section{حدود البحث:}

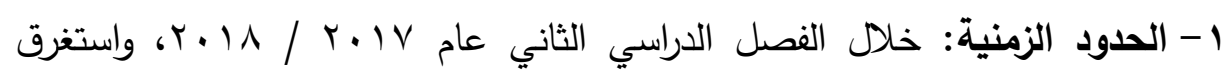

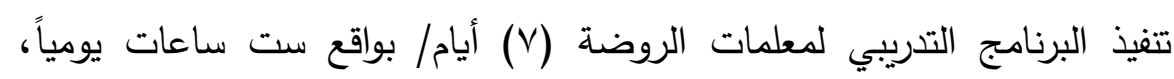

$$
\text { إجمالي (Y \& ) ساعة. }
$$


ץ- الحدود المكانية: روضات أربعة مدارس بادارة القاهرة الجديدة التعليمية، وهي:

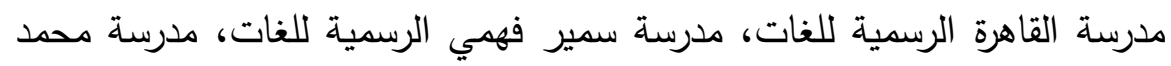
وحيد الرسمية للغات، مدرسة صلاح الدين الرسمية للغات.

r- الحدود البشرية: عينة عشوائية من معلمات رياض الأطفال، وكان قوامها (•ـ)

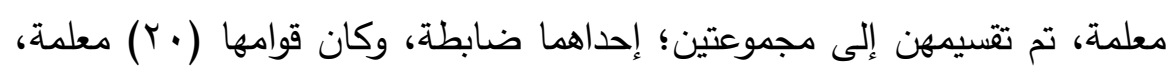
والأخرى تجريبية، وكان قوامها ( • (ب) معلمة.

ع - الحدود الموضوعية: يقتصر البحث الحالي علي تتمية بعض المهارات الناعمة

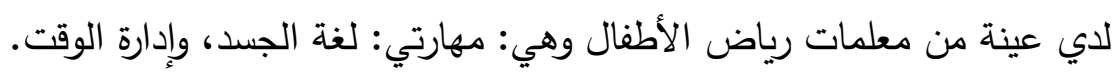

\section{التصميم التجرببي للبحث :}

سوف يستخدم الباحث التصميم التجريبي ذو المجموعتين التجريبية والضابطة. أدوات البحث: - n - n

1- قائمة المهارات الناعمة لمعلمات رياض الأطفال( إعداد الباحث ). ץ - البرنامج التدريبي المقترح لمعلمات رياض الأطفال( إعداد الباحث ). r- بطاقة ملاحظة المهارات الناعمة(مهارة لغة الجسد - مهارة إدارة الوقت)لدي معلمات رياض الأطفال(إعداد الباحث).

ع - اختبار تحصيلي المهارات الناعمة(مهارة لغة الجسد- مهارة إدارة الوقت) لدي معلمات رياض الأطفال(إعداد الباحث).

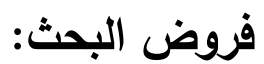

1 - يوجد فرق دال إحصائياً بين متوسطات درجات المعلمات أفراد المجموعة التجريبية

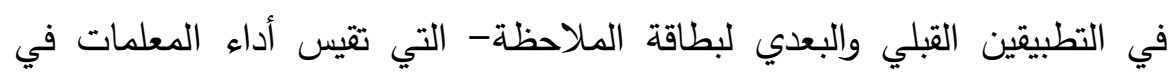
مهارتي: لغة الجسد، وإدارة الوقت - لصالح التطبيق البعدي. 
r - يوجد فرق دال إحصائياً بين متوسطات درجات المجموعتين التجريبية والضابطة في التطبيق البعدي لبطاقة الملاحظة- التي تقيس أداء المعلمات في مهارتي: لغة دئل الجسد، وإدارة الوقت - لصالح المجموعة التجريبية.

ץ- يوجد فرق دال إحصائياً بين متوسطات درجات المعلمات أفراد المجموعة التجريبية في التطبيقين القبلي والبعدي للإختبار التحصيلي- في مهارتي: لغة الجسد، وإدارة دارة الوقت - لصالح التطبيق البعدي.

ع - يوجد فرق دال إحصائياً بين متوسطات درجات المجموعتين التجريبية والضابطة في التطبيق البعدي للإختبار التحصيلي- في مهارتي: لغة الجسد، وإدارة الوقتلصالح المجموعة التجريبية. ه- يوجد ارتباط طردي بين متوسطات درجات المعلمات في المهارات الناعمة(مهارة

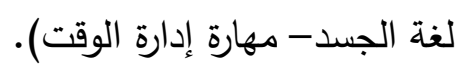

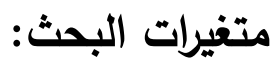

1- المتغير المستقل: يتمثل فى البرنامج التدريبي المقترح لمعلمات رياض الأطفال. r - المتغير التابع: يتمثل في بعض المهارات الناعمة(لغة الجسد، وإدارة الوقت).

\section{منهج البحث وإجراء اته:}

استخدم المنهج الوصفى فى الجانب النظري، والمنهج التجريبى فى الجانب التطبيقي. ولإجابة عن أسئلة البحث والتحقق من صحة فروضه اتبعت الإجراءات التالية:

1 - مراجعـة البحـوث، والدراسـات، والأدبيـات التربويـة المرتبطـة بالمهـارات الناعمـة،

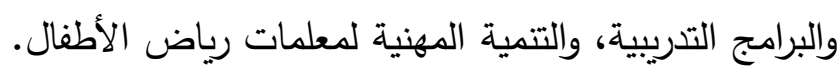

r - بنـاء إطـار نظري يتتـاول الففـاهيم النظريـة والأسس التربويـة المرتبطـة بمتغيرات البحث.

r- اختيار عينة البحث: وعددها • ـ معلمة، تم تقسيمهن إلى مجموعتين؛ إحداهما

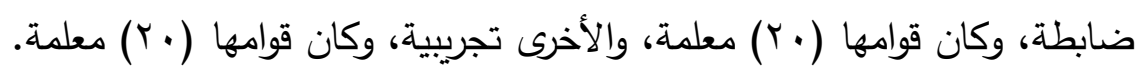


ع - تحديد قائمة المهارات الناعمة لمعلمات رياض الأطفال.

ه - عرض القائمة علي مجموعة من المحكمين وتعديلها وفقاً لأرائهم.

צ- عرض القائمة في صورتها النهائية علي معلمات رياض الأطفال (عينـة البحث)

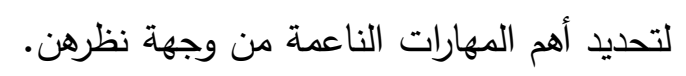

- V وضع تصور لبرنامج تدريبي لتتمية بعض المهارات الناعمة(مهارة لغة الجسد-

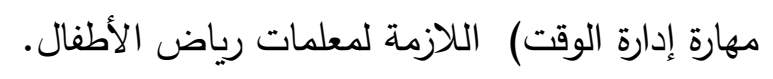

^- عرض البرنامج التدريبي المقترح على مجموعة من المحكمين، وتعديله وفقا لأرائهر.

$$
9 \text { - إعداد أداتي البحث وضبطهما: }
$$

- بطاقـة ملاحظــة لقيـاس بعض المهـارات الناعمــة(مهارتي: لغــة الجســ،

$$
\text { وإدارة الوقت) لدي معلمات رياض الأطفال. }
$$

- اختبار تحصيلي المهارات الناعمة(مهارة لغة الجسد - مهارة إدارة الوقت)

$$
\text { لاي معلمات رياض الأطفال. }
$$

• 1 - عرض أداتي البحث على مجموعة من المحكمين، وإجراء التعديلات اللازمة فى ضوء

$$
\text { آرائهم وحساب صدق وثبات كل أداة. }
$$

1ا- التطبيق القبلي لبطاقة الملاحظة، والأختبار التحصيلي على المجموعتين التجريبية،

$$
\text { والضابطة (عينة البحث). }
$$

r ا - تطبيق البرنامج التدريبي المقترح علي المجموعة التجريبية. ب ا - التطبيق البعدي لبطاقة الملاحظة، والأختبار التحصيلي علي المجموعتين التجريبية،

$$
\text { والضابطة (عينة البحث). }
$$

؛ ا - رصد النتائج، وتحليلها، وتقسيرها فى ضوء أسئلة البحث وفروضهه، وتقديم التوصيات،

$$
\text { والمقترحات. }
$$




\section{مصطلحات البحث:}

المهارات الناعمة "Soft Skills"

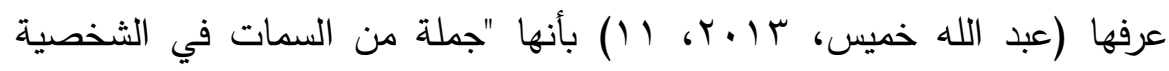
ترتبط بمجال التواصل مع الآخرين في جو من الود والتعاون، وتعكس مقدار الأريحية التي

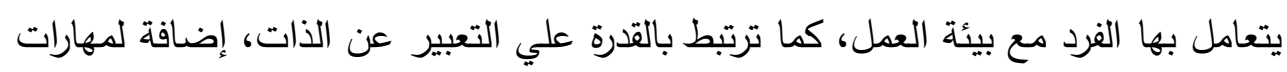
عرض الأفكار بصورة جذابة".

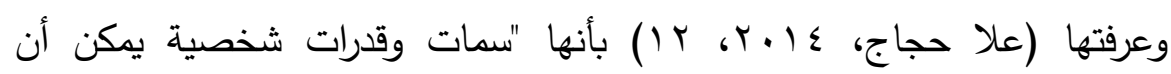

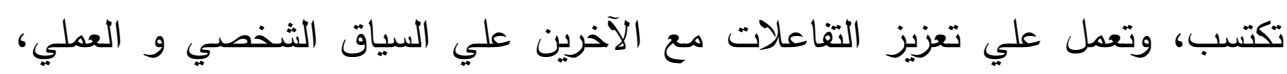

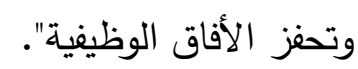

ويعرفها " الباحث " إجرائيا بأنها: القدرات التي تمتلكها معلمة الروضة، وتساهم في

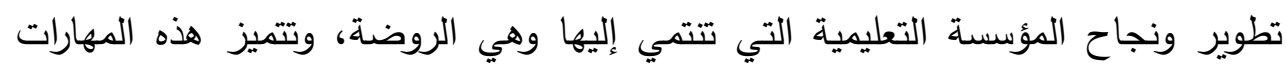

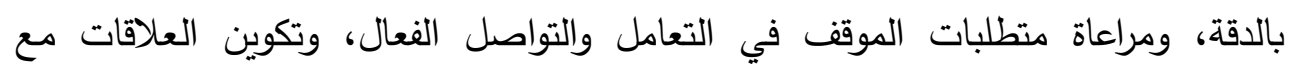
الآخرين وهم: الأطفال، والزملاء داخل الروضة، والقيادات، وأولياء الأمور .

\section{لغة الجسد "Body Language":}

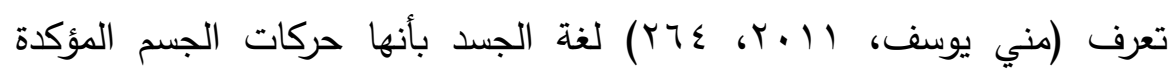
لحديثك، وما تريد أن ترسله من كلمات، والتي تصنعها تعبيرات الوجه، العين، واليدين، والكتفين، والذراعين، وقد تكون الأقدام.

ويعرف " الباحث " لغة الجسد إجرائيا بأنها: حركات الجسم المؤكدة لحديث معلمة

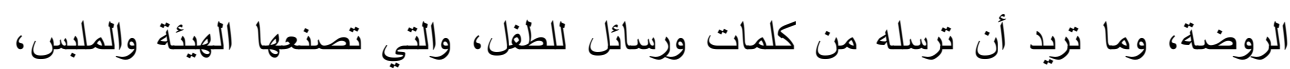

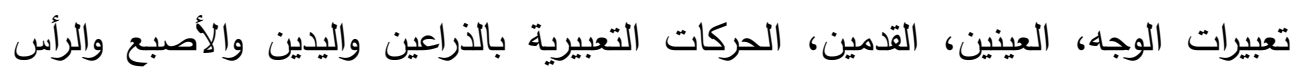

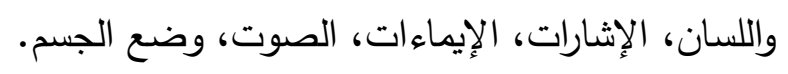


إدارة الوقت "Time Management":

تعرف إدارة الوقت أنها عملية الأستفادة من الوقت المتاح والمواهب الثخصية

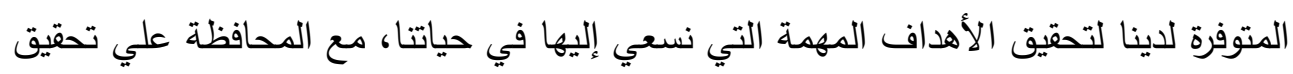
التوازن بين متطلبات العمل والحياة الخاصة، وبين حاجات الجسد والروح والعقل (إبراهيم

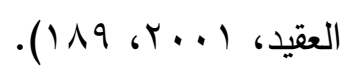

ويعرف "الباحث" إدارة الوقت إجرائيا بأنها: عملية استفادة المعلمة من الوقت

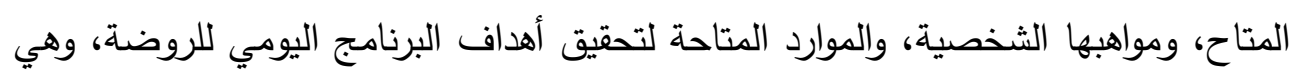
عملية قائمة علي التخطيط والتنظيم والمتابعة والتتسيق والتحفيز والاتصال.

البرنامج التدريبي "Training program":

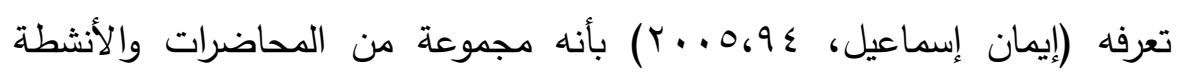
والممارسات العملية والمواقف التي تهدف إلي تتمية مهارات ومعلومات وممارسات معلمات إنهات رياض الأطفال، والتي صممت من أجل معرفة معلمة الروضة كيفية التعامل مع الأطفال في حدود الإمكانيات المتاحة لهن.

ويعرفه "الباحث" إجرائيا بأنه: مجموعة من الخبرات، والمهارات، والخطوات،

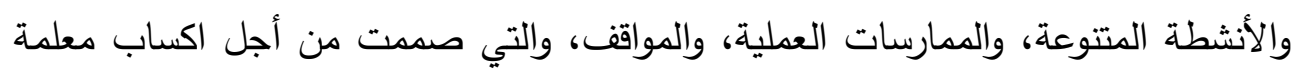

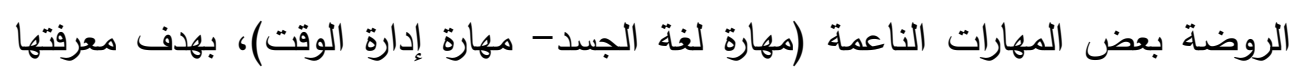

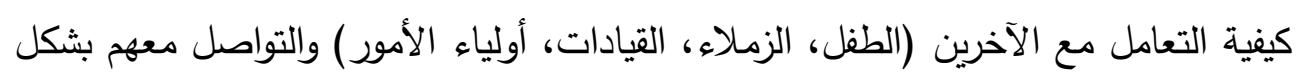
جيد في حدود الإمكانيات المتاحة. الإطار النظري والدراسات السابقة: المحور الأول: المهارات الناعمة:

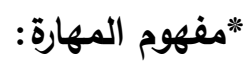
هي أي شيء تعلمه الفرد ليؤديه بسهولة ودقة، ويمكن تعلم هذا الثيء أو اكتسابه أو تكوينه لدي المتعلم عن طريق الدحاكاة والتدريب. 


\section{"مفهوم المهارات الناعمة:}

عرفها (عبد الله خميس، با ـ r، 1) (1) بأنها "جملة من السمات في الثخصية ترتبط بمجال التواصل مع الآخرين في جو من الود والتعاون، وتعكس مقدار الأريحية التي يتعامل

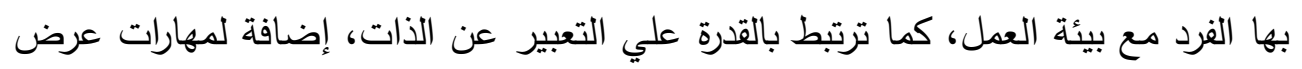

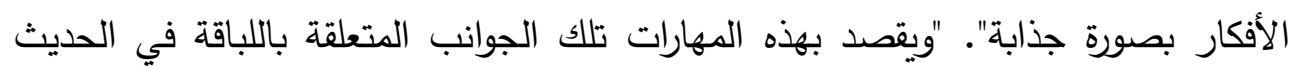
والمظهر الجيد والمتميز ، والتحلي بملكات خاصة تبرز المتقدم للوظيفة وسط أقرانه" (فايزة

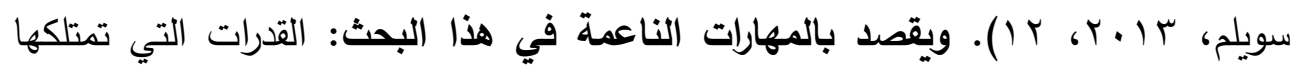
معلمة الروضة، وتساهم في تطوير ونجاح المؤسسة التعليمية التي تتنمي إليها وهي

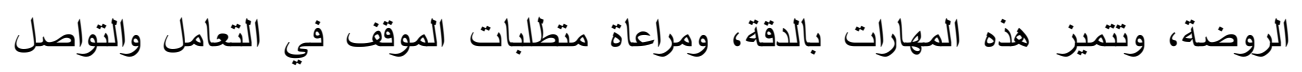

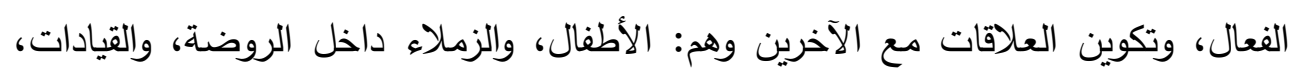

$$
\text { وأولياء الأمور . }
$$

\section{*المهارات الناعمة مقابل المهارات الصلبة:}

عندما ينتقل الثخص من مرحلة التعلم إلى سوق العمل، يشعر أن هناك اختلاف

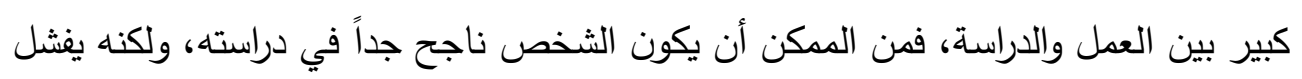
عندما يبدأ في العمل، وهذا يرجع إلى أنه يفتقد إلى المهارات الناعمة، التي تجعله متميز

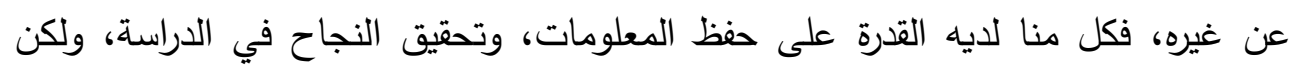
القليل منا من يستطيع أن ينجح في سوق العمل.

المهارات الناعمة هي تلك المهارات التي يحتاجها الشخص حتى ينجح في سوق

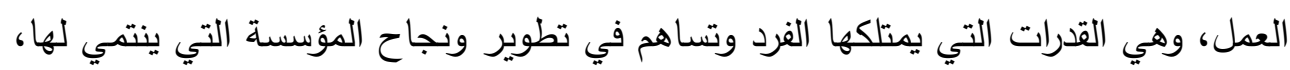

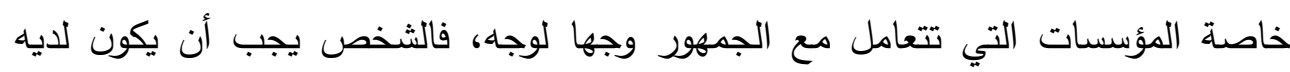
القدرة على خلق علاقات مع الآخرين.

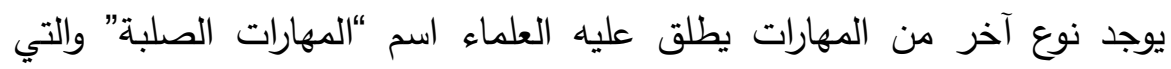
تتمثل في الخبرة والمؤهلات، وتشمل مهارات العمل مثل القراءة، والكتابة، والرياضيات، والقدرة علي استخدام برامج الحاسب الآلي، وتلك المهارات تساعدك على على الإلتحاق 
بالوظائف، ولكنها لا تمكنك من الاستمرار بها، أما المهارات الناعمة فهي تقودها الشخصية

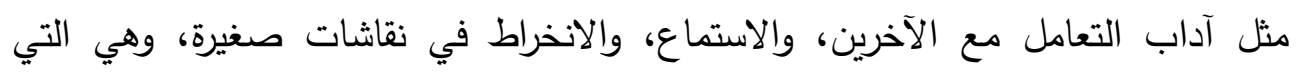
تساعدلك على النجاح والتفوق، وتمكنك من أن تصبح في مكانة مرموقة فيما بعد والتئي .(Investopedia, 2014,2)

"أهمية المهارات الناعمة:

كلا من المهارات الناعمة والصلبة مهمة عند التقدم بطلب لوظيفة معلم أو معلمة، وبينما تكون المهارات الصلبة هي سبب الحصول علي المقابلة فإن المهارات الناعمة هي لهي السبب في الحصول علي الوظيفة، لأن أصحاب ومديري المدارس يبحثون عن الأشخاص

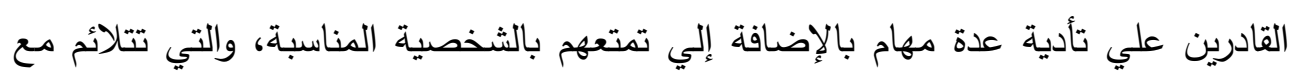
المؤسسة التعليمية، وتعطي انطباع جيد عنها لأولياء الأمور (Investopedia 2014,2). إن أصحاب ومديري المدارس يريدون المعلمين الجدد الذين يملكون مهارات ناعمة،

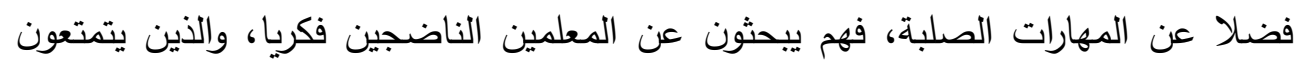
بقدرة علي التواصل الأجتماعي، ويقيمون المهارات الناعمة علي أنها من المهارات الهامة لئن

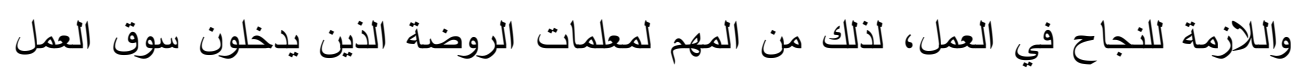

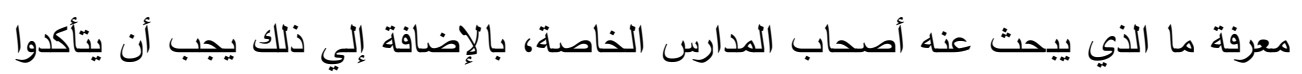
من أن مهاراتهم تتناسب مع المهارات المطلوبة من قبل أصحاب ومديري تلك المدارس. وأظهرت العديد من الدراسات مدي أهمية المهارات الناعمة لدي أصحاب ومديري

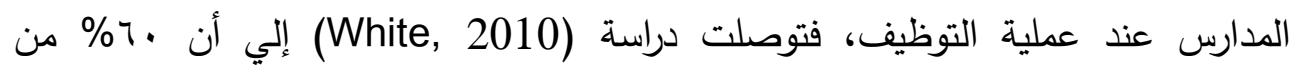

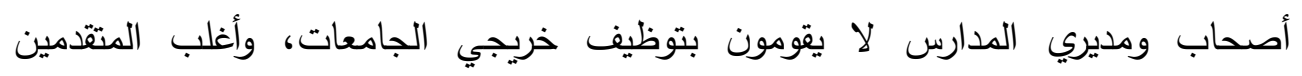

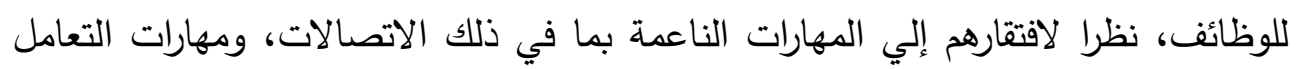
مع الآخرين، والتفكير النقدي، كما هدفت دراسة (Schulz, 2008) إلي توضيح مدي لفي

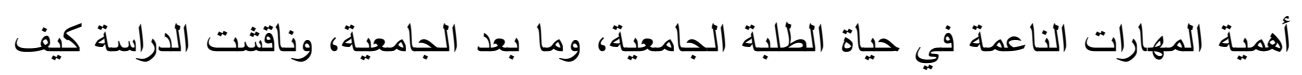

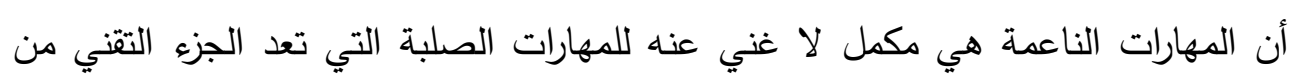

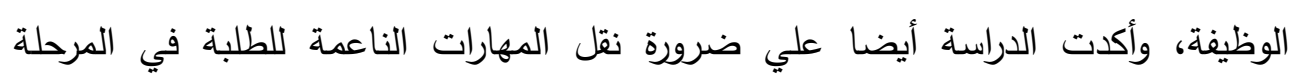


الجامعية لتجهزيهم لسوق العمل بشكل أفضل. فخريجي كليات التربية، ومنهم معلمات رياض الأطفال لا يرتقون للمعايير المطلوبة في سوق العمل، وذلك بسبب وجود فجوات بين المهارات التي يطالب بها أصحاب ومديري المدارس، وما تقدمه المؤسسات التعليمية، وهدفت دراسة (Andrews, Higson, 2010) إلي معرفة رأي كل من الطلبة وأصحاب

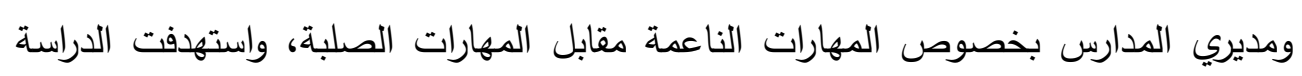
أربع دول أوربية لديها قطاعات مختلفة عن بعضها البعض في مستويات التعليم العالي،

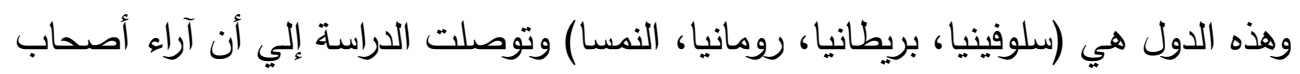

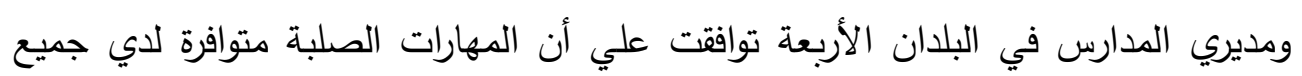

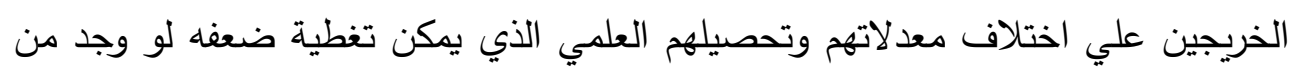

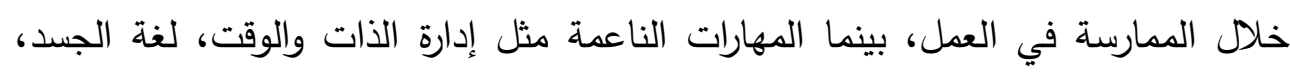

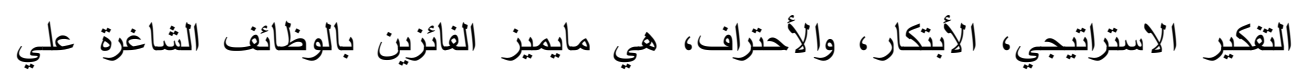
غيرهم من المتقدمين.

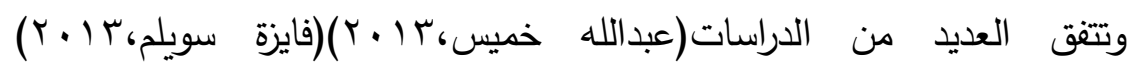
، (Siti, 2015) Investopedia.,) (2014,

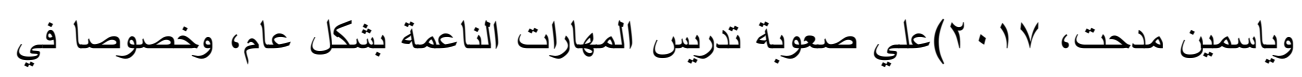
قاعات الدراسة، ويري آخرون أن المهارات الناعمة من الممكن أن يتم تدريسها أو اكتسابها

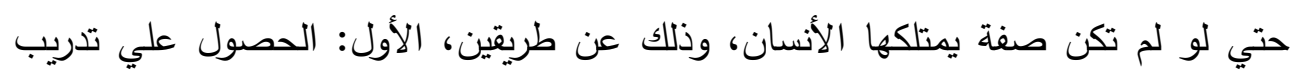

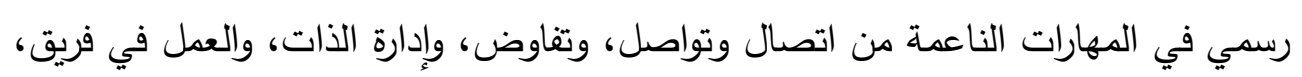

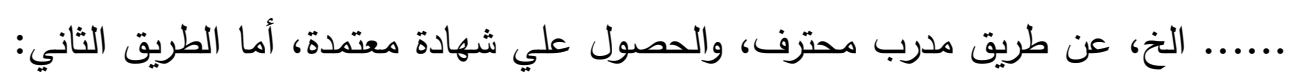

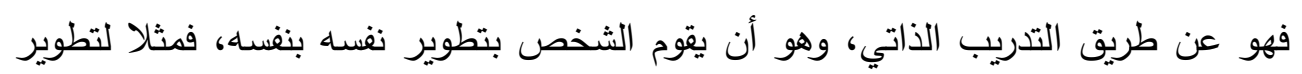

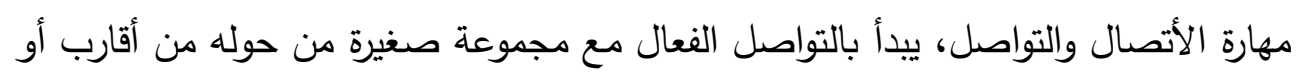
جيران أو معارف، ومن ثم يطورها بالممارسة شيئا فشيئا.

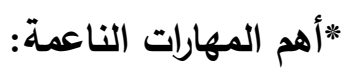
المهارات الناعمة كثيرة ومتعددة، وتختلف من مجال عمل إلي آخر ، ولكن وفق دراسة قامت

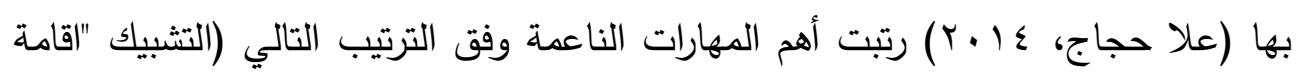


علاقات اجتماعية سوية مع الآخرين"، التفكير الناقد، تقديم الذات، الأحتراف، ادارة الأزمات، التفاوض، ادارة الغضب)، وتوصلت نتائج الدراسة إلي وجود علاقة ذات دلالة احصائية بين الإنيل عملية اقتتاص الوظائف، والمهارات الناعمة، وأوصت الدراسة الباحثين عن عمل أن يعملوا

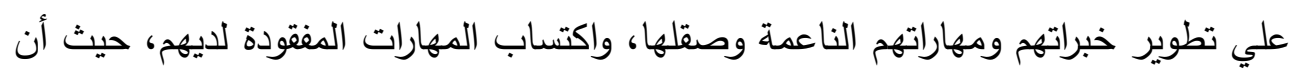
الوظائف لا يكون التركيز فيها علي التخصص الجامعي أو المعدل الجامعي فقط. ووفق دراسة قام بها (Robles, 2012) رتب أهم عشر مهارات ناعمة وفق الترتيب التالي (الاستقامة والنزاهة، الاتصال والتواصل، المجاملة وأدب السلوك، المسئولية،

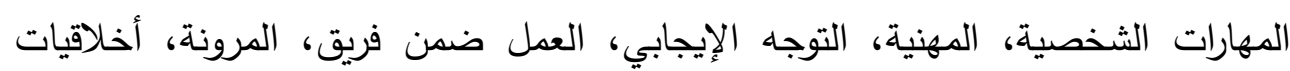

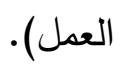

أما دراسة (مؤمن خلف، 17 ـ ب) توصلت إلي أن هناك علاقة ذات دلالة احصائية بين عملية اقتتاص الوظائف الأكاديمية وكل من المهارات الناعمة (تقديم الذات، التفكير الناقد، التشبيك "(قامة علاقات اجتماعية سوية مع الآخرين").

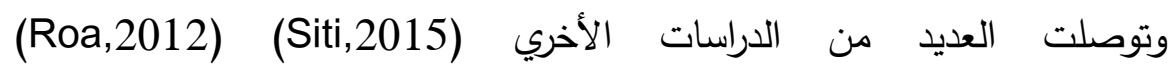
(Lazarus,2013) (Coscia,2013)

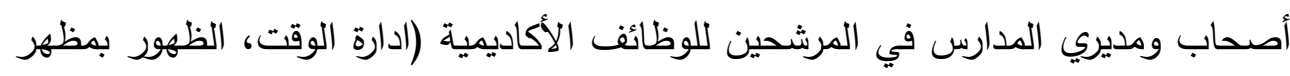

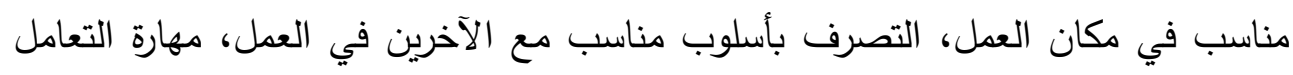

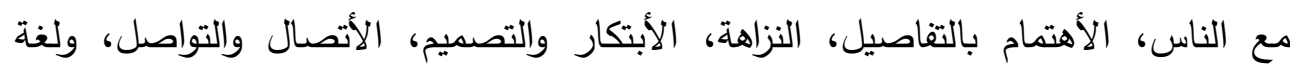

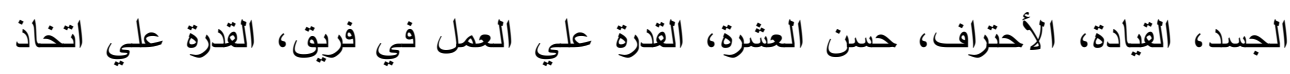

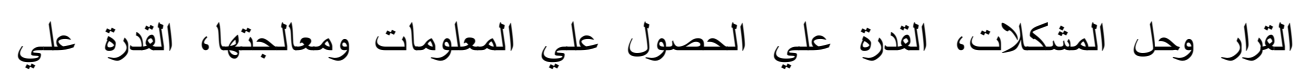
التخطيط والتنظيم وتحديد الأولويات، القدرة علي تحليل البيانات الكمية).

وفي ضوء الدراسات السابقة، والأطار النظري، ورأي الخبراء في المناهج وطرق

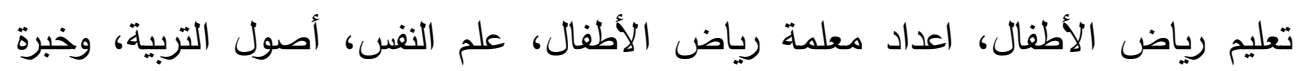
الباحث في الأشراف علي طالبات شعبة رياض الأطفال بالتربية الميدانية، وملاحظة

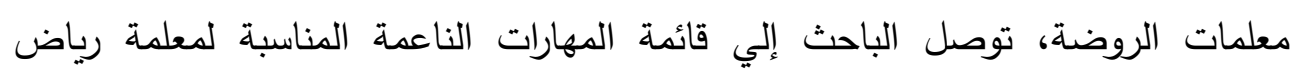


الأطفال (ملحق ()، وسيتم عرض مهارتي فقط من المهارات الناعمة، والتي تتاولها الباحث في دراسته، والمتضمنة في البرنامج التدريبي للمعلمات- عينة البحث- والتي حصلت علت علي التي أعلي تكرار بعد تحكيم معلمات الروضة علي القائمة، وهما مهارات الاتصال الفعال، (وتتضمن مهارة لغة الجسد) ومهارة ادارة الوقت.

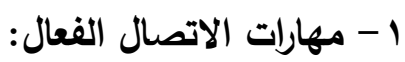

يعد التواصل جانبا مهما في العملية التعليمية، فهو أداة فعالة من أدوات التغيير

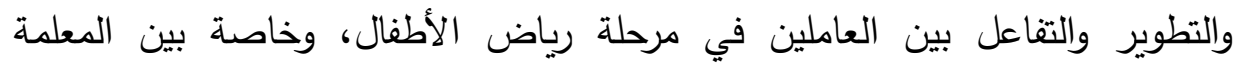

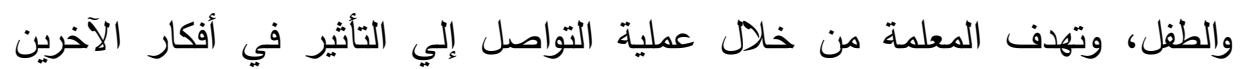

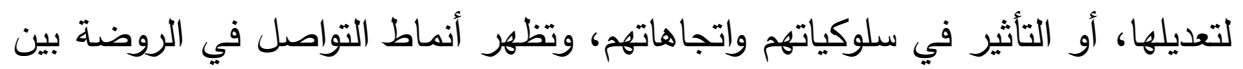

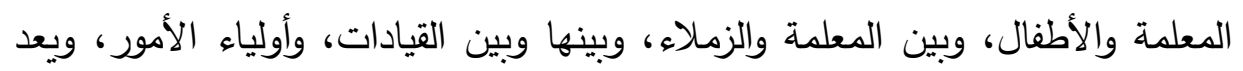

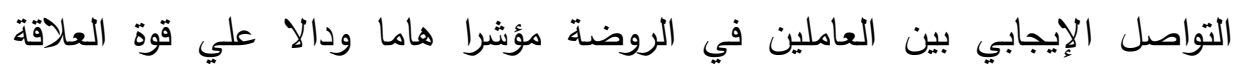

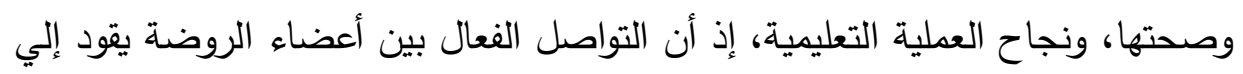
الرضا بين أعضاء الروضة، ويعمل علي تقليل النزاعات والمشاكل داخل الروضة. وينظر إلي التواصل بين أعضاء الروضة كأساس لجودة العملية التعليمية في

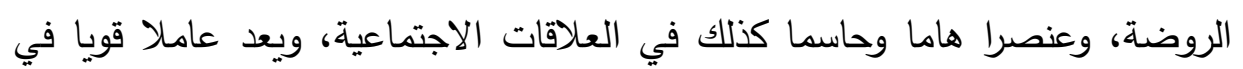

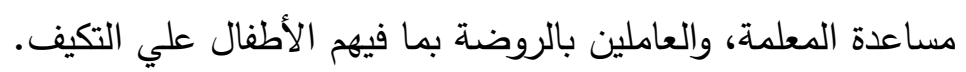
ويعد التواصل عملية تفاعلية بين شخصية ذات محتوي معين تتم داخل سياق محدود، وتتضمن نقل حقائق وتلقيها، وإدراك مشاعر وأحاسيس واتجاهات وأفكار

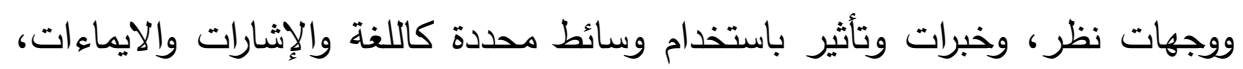
وغيرها من أساليب التواصل اللفظي، وغير اللفظي يهدف منها المرسل التأثير علي

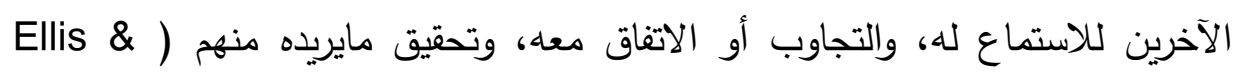
.(Crawford, 2000,16 


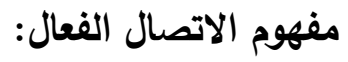

الاتصال الفعال هو نقل المعلومات بشكل دقيق، وواضح، ومتبادل، لا يحتمل التأويلات والتفسيرات المختلفة مع الاستماع للمتحدثين بانتباه واستخدام أفضل الوسائل

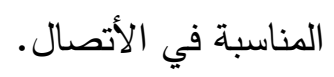

ويري (أحمد ماهر ، T × . T، VT) بأن الاتصال الفعال هو وضع الأفكار في رسالة

وبثها بوسيلة قياسية بحيث يمكن أن يفهمها الطرف الأخر ، ويتصرف بالثكل المطلوب.

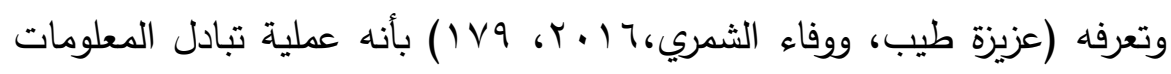

والأفكار بين المشرفة التربوية والمعلمات بشكل يحقق أقصي درجات التواصل باستثماره كافة

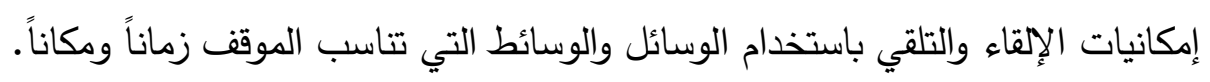
ويعرف الباحث الأتصال الفعال بأنه سلوك مقصود من جانب المعلمة ينقل الأفكار

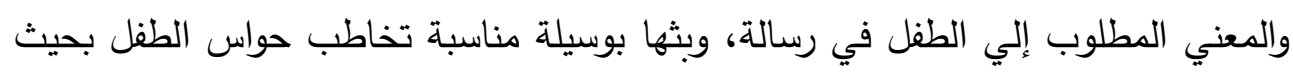
يمكن أن يفهها، ويستجيب لها بالسلوك المطلوب منه، ويتصرف بالثكل المطلوب.

مفهوم مهارات الاتصال الفعال: - م

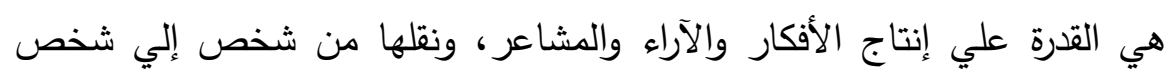

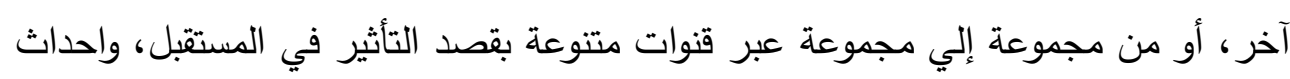

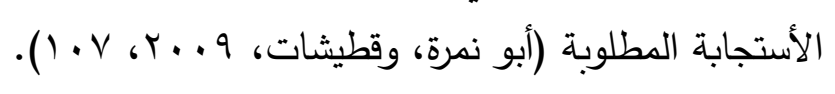

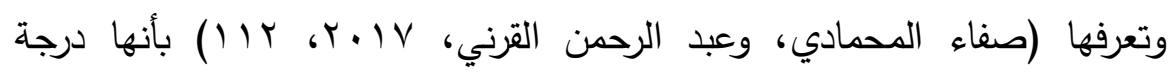

ممارسة المشرفات التربويات لمهارات الأتصال الفعال (مهارة التحدث، مهارة التراء التراءة، مهارة

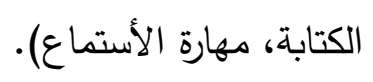

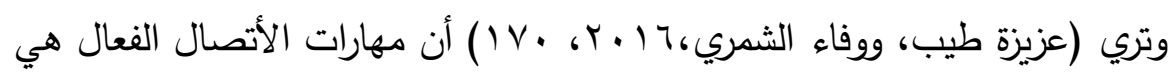

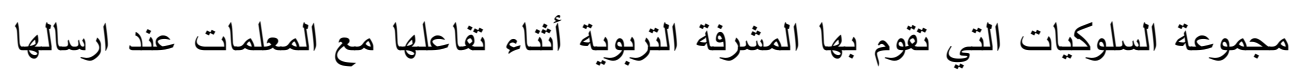

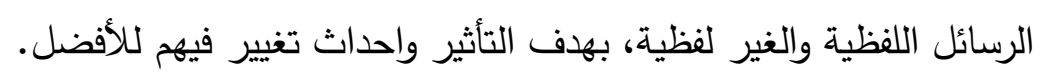


ويعرف الباحث مهارات الأتصال الفعال بأنها مجموعة السلوكيات التي تقوم بها معلمة الروضة أثناء تفاعلها مع الأطفال بهدف نقل الأفكار والآراء والمشاعر إليهه، والتأثير فيهم، واحداث الأستجابة المطلوبة، والتغيير للأفضل.

أهمية الاتصال الفعال: - n

- يسمح بالمواجهة بين المعلمة والطفل، يخلق نوعاً من التعاون والألفة بين طرفي

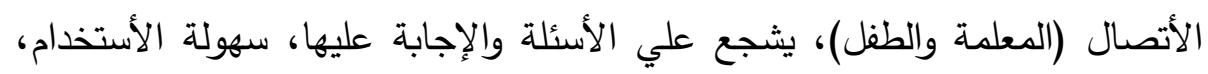
حيث لا يحتاج إلي وقت كبير للتحضير والإعداد له، يحدث وعياً أو تذكراً ملحوظاً

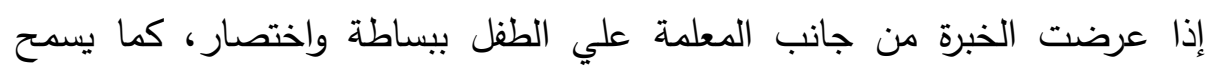
بالتعرف علي نفسية المحاور - المعلمة - من خلال ملاحظة ألفاظه وما يصاحبها

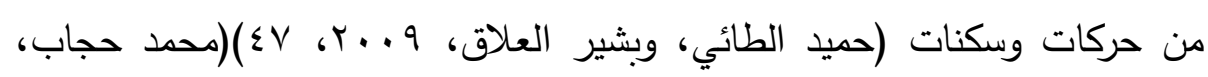

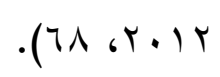

أهداف الاتصال الفعال: - n

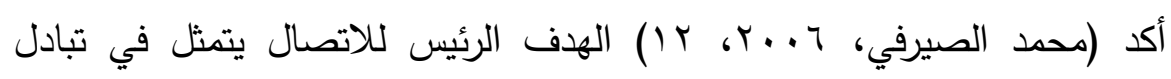

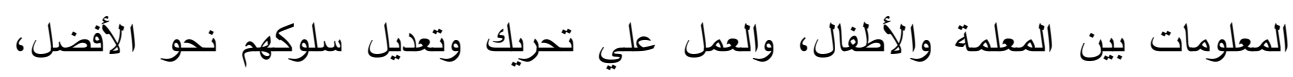

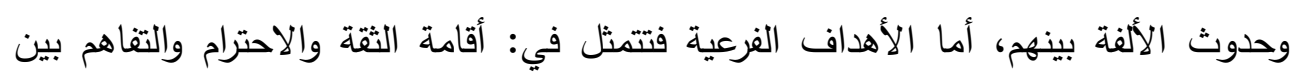
المعلمة والأطفال، شرح وتوضيح أهداف النشاط، وخطط العمل للأطفال، نقل المعلومات، والتأكد من تحقيق التعاون بين الأطفال بعضهم البعض، وبين المعلمة والأطفال، قيادة

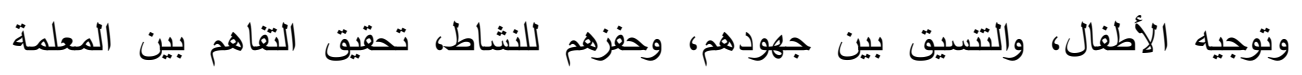
والأطفال، وبين المعلمة وأولياء الأمور، تحقيق التفاهم بين المعلمة والعاملين بالروضة وحفزه

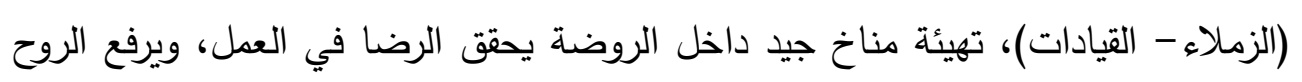
المعنوية للمعلمة والأطفال.

عناصر ومكونات عملية الاتصال الفعال:

تعرف عملية الاتصال بأنها نقل فكرة أو معلومات ومعان (رسالة) من شخص (مرسل) إلي شخص (مستقبل) عن طريق قناة اتصال (تختلف باختلاف المواقف)، وتنتقل 
الرسالة عبر قناة الاتصال علي شكل رموز مفهومة ومتفق عليها بين المرسل والمستقبل، أو رموز شائعة في المجتمع. هذا وقد تصل الرسالة سليمة ويفهمها المستقبل فهما صحيحا

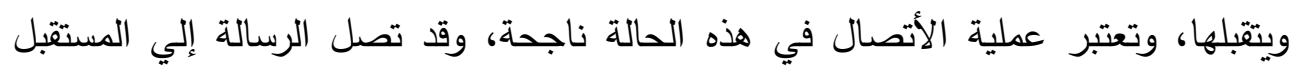

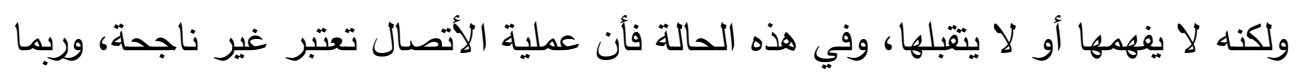
لا تصل الرسالة علي الاطلاق لسبب أو لآخر أو قد تصل ناقصة أو مشوشة الوانة (الموسوعة

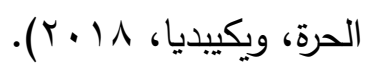

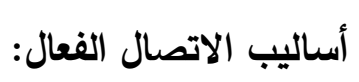

\section{يمكن تقسيم الاتصال الفعال إلي مجموعتين:}

1- الاتصال اللفظي: ويدخل ضمن هذه المجموعة كل أنواع الاتصال التي يستخدم فيها اللفظ كوسيلة لنقل رسالة من المرسل إلي المستقبل.

r- الاتصال غير اللفظي: وتشمل هذه المجموعة كل أنواع الاتصال التي لا تعتمد

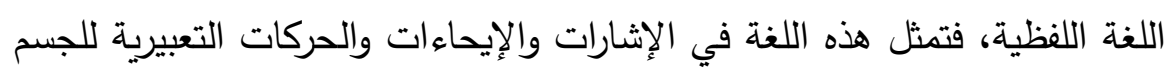
كتعبيرات الوجه والعين واليدين والكتفين والذراعين وقد تكون الأقدام، التي يستخدمها الإنهات الشخص لنقل فكرة أو معني إلي شخص آخر يصير مشتركاً معه في الخبرة. مشكلات ومعوقات الاتصال الفعال: لا يتم الاتصال في الروضة بدون مشاكل أو معوقات؛ فقد تظهر بعض مصادر

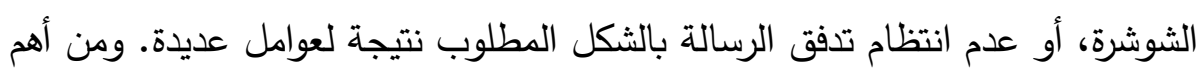

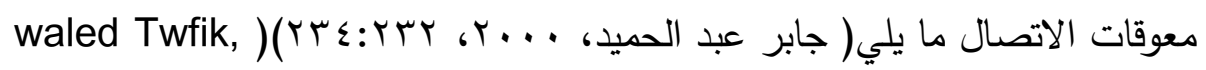
:(Kenan, 2018 ,69)(2009,97

معوقات شخصية: تتعلق بالمرسل أو المستقبل أو بكليهما، وما يحمله كل منهما

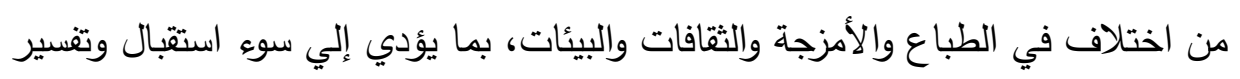

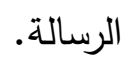


معوقات مادية: تتعلق بالوسيلة أو الرسالة أو البيئة، وهي تلك المعوقات الناتجة عن البيئة الفيزيقية لعملية الاتصال من ضوضاء خارجية، أو أصوات فيزيقية، وحرارة

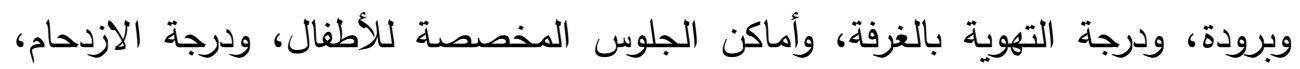
ووسائل الراحة المتاحة، وجميع المشتتات الحسية الأخري التي تعيق عملية التواصل. معوقات فنية: ونعني بها كل المعوقات الناتجة عن الإخلال بالشروط الواجب

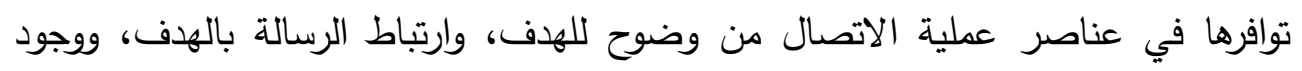

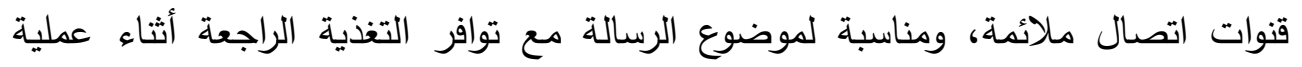
الاتصال وبعدها بما يؤدي للتفاعل والاستمرارية.

معوقات لفوية: وهي تلك المعوقات الناتجة عن الاستخدام اللفظي للغة، وكذلك الاستخدام غير اللفظي. حيث نجد أنه عند استخدام اللغة قد نقع في بعض المحاذير مثل الخدئ استخدام مفردات لغوية غامضة علي الطفل، والتي تحمل أكثر من معني لديه، والسرعة في الكلام، وعدم الاستخدام الأمثل للوقفات، أما اللغة غير اللفظية من استخدام للإشارات

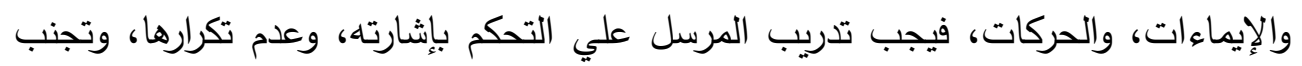
الإثارات السلبية المسيئة. معوقات إدراكية: وتعني المعوقات الناتجة عن الإدراك المسبق عند كل من المرسل والمستقبل لموضوع الرسالة. مهارات الاتصال الفعال: - مهال تلعب مهارات الاتصال دورا كبيرا في فهم واستقبال الرسالة، فكلما زادت مهارات

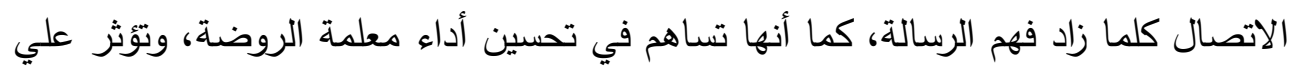
سلوكها وردود أفعالها، والمهارة بشكل عام هي عبارة عن سرعة في الأداء الجيد يتم اكتسابها

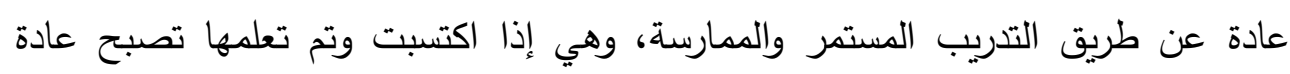
متأصلة في سلوك المعلمة. وتتمية هذه المهارات أصبح أمرا ضروريا لمعلمات الروضة أيا كانت ثقافتهم

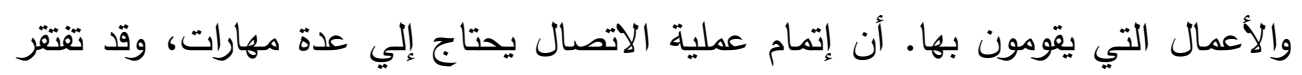


عملية الاتصال إلي أهم شروط نجاحها وفعاليتها بدونها؛ ومن هذه المهارات: مهارة

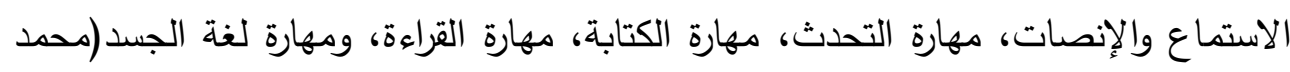

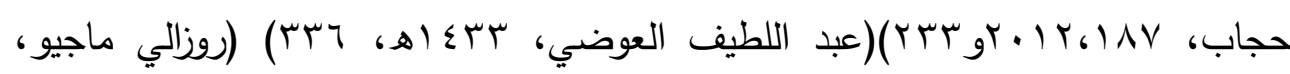
مدكو ، Y...

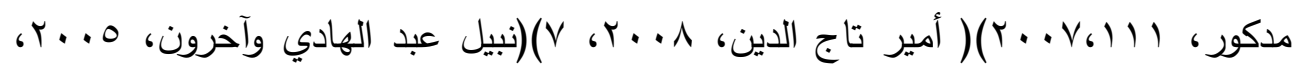

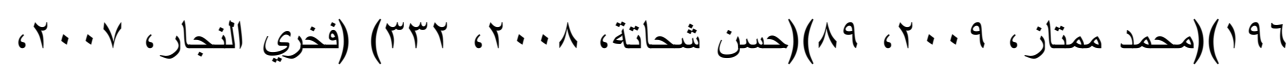

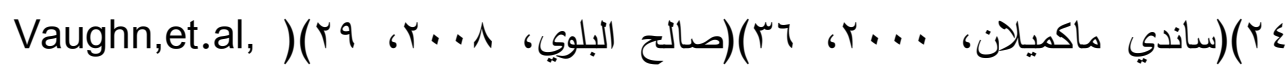
(2006, 23 . وسوف يتناول الباحث مهارة لغة الجسد بشيء من التفصيل، وهي احدي المهارات المستهدف تتميتها لدي عينة البحث.

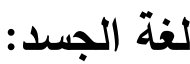

تلعب الإشارات والإيماءات الصادرة عن جسم الإنسان في المواقف المختلفة دورًا

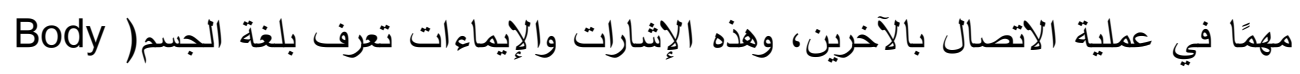

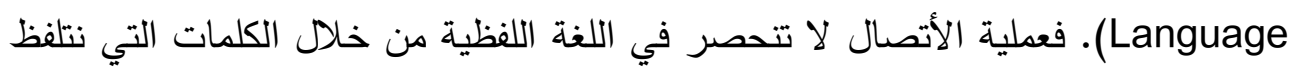
بها فقط، بل يجب أن تمتد لما هو اشمل، فإذا أردنا أن نفهم شخصًا فعلينا أن ننظر إليه ونتعرف علي الإشارات والإيماءات التي تصدر عنه، وهو ما يعرف بلغة الجسد، حيث إن إن إن إنهاء

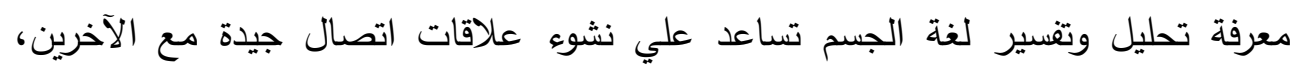

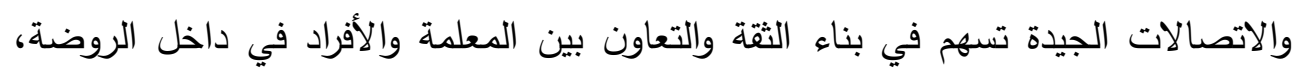

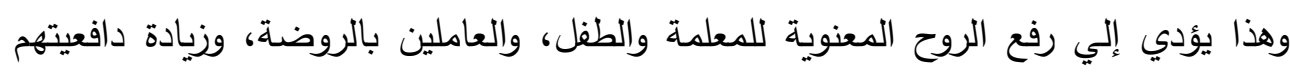

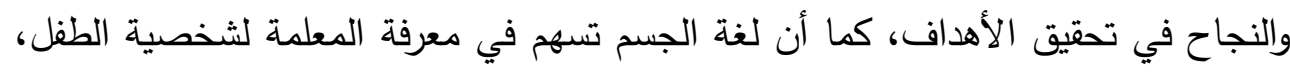

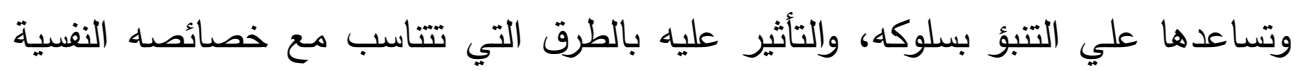
والعقلية والجسمية.

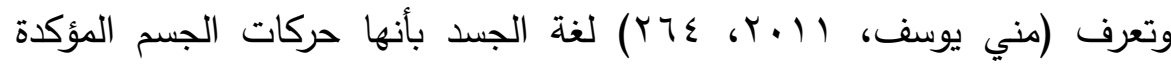
لحديثك، وما تريد أن ترسله من كلمات، والتي تصنعها تعبيرات الوجه، العين، اليدين،

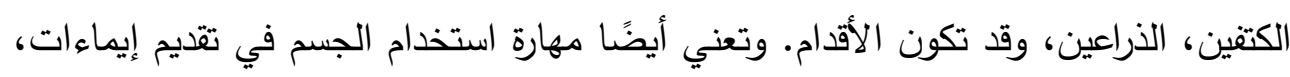


وحركات، وتعبيرات تسهم بشكل إيجابي في إيضاح معني الرسالة التي يود المرسل إرسالها

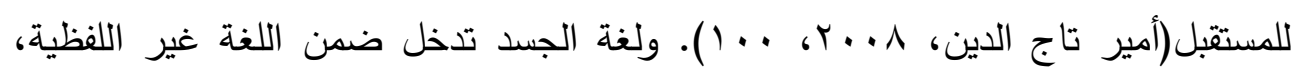

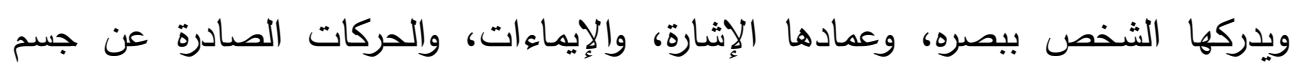
الثخص أثناء الانفعالات المختلفة.

\section{أهمية لغة الجسد في الاتصال:}

استخدام لغة الجسد أثناء التعبير يضفي علي الرسالة الوضوح، ويضفي علي

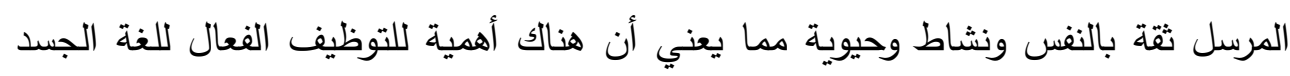
لكل من المرسل والرسالة.

ولغة الجسد وما تحتويه من إثارات وإيماءات تلعب دورًا مهمًا في عملية الاتصال

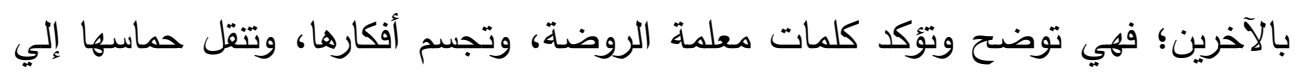

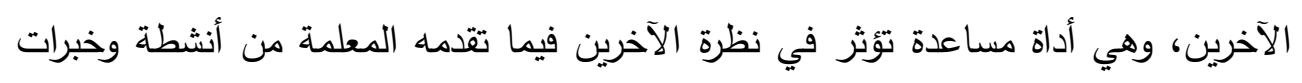

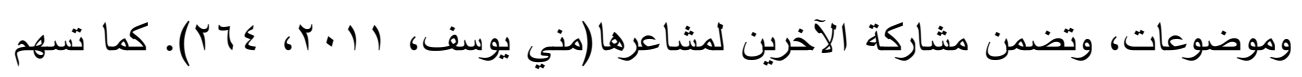

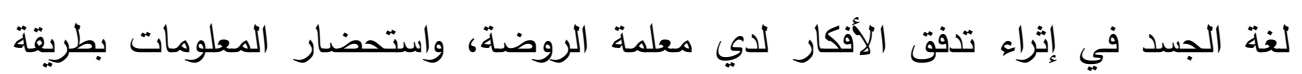

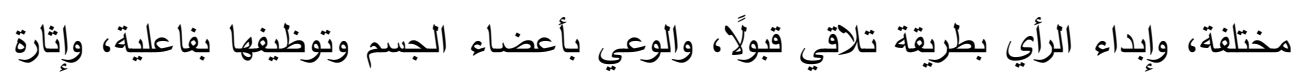
المتعة لدي الأطفال، وإقناعهم بطرق جديدة. وتأخذ الإشارات والإيماءات الصادرة عن جسم الإنسان أشكالًا عديدة منها:

$$
\text { * * التعبير بالثفتين. }
$$

* التعبير من خلال حركات الرجلين.

$$
\text { * التعبير بملامح الوجه. }
$$

* التعبير بلغة العيون. * التعبير بالرأس. * التعبير بالأنف. 
وهناك لغات وأشكال أخري لها صلة بلغة الجسم، والاتصال غير اللفظي: * لغة الاكسسوارات والأشياء التي يستخدها الإنسان.

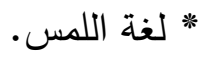

* لغة الملابس (الملبس والمظهر).

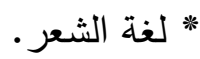
* الدلالات الرمزية للمسافة والمكان.

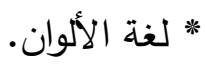
* الدلالات الرمزية للزمن واستخدام الوقت.

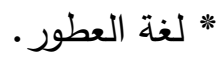

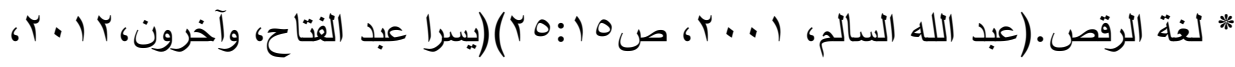

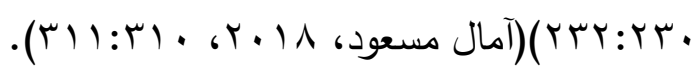

وفي حدود علم الباحث لا توجد دراسة تتاولت تتمية المهارات الناعمة لدي معلمة الروضة، وخاصة مهارات التواصل غير اللفظي (مهارة لغة الجسد)، ولكن أظهرت العديد

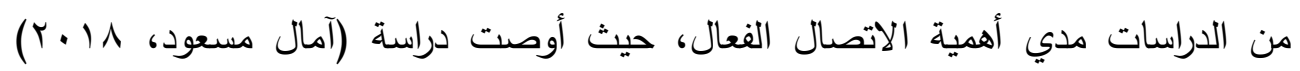
بوجوب اهتمام الروضة بتحقيق التواصل مع الأسرة، كأحد الاستراتيجيات والمداخل الأساسية الأية

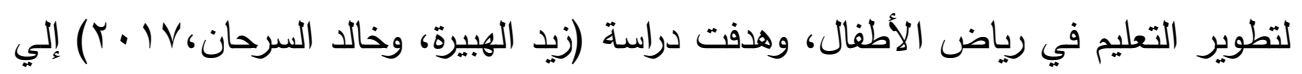
اقتراح برنامج تدريبي لتطوير مهارات الاتصال الفعال لدي مديري المدارس في المدلكة الديدة

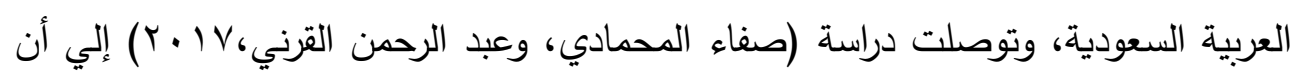

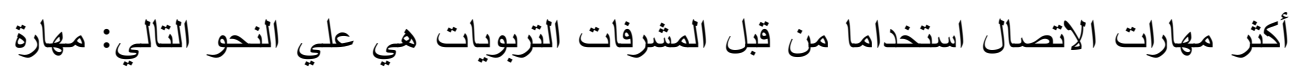
القراءة، وحصلت علي أعلي متوسط حسابي، ثم مهارة التحدث في المرتبة الثانية، يليها مهارة الاستماع في المرتبة الثالثة، ثم مهارة الكتابة في المرتبة الرابعة والأخيرة، أما دراسة

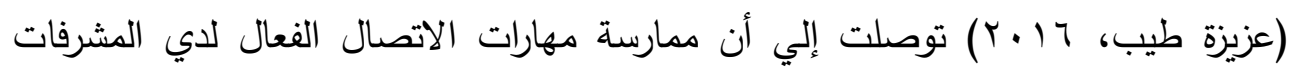
التربويات جاءت بدرجة ممارسة عالية جدًا، من وجهت نظر المعلمات، وكانت أبرز

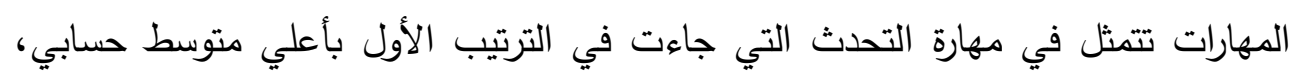

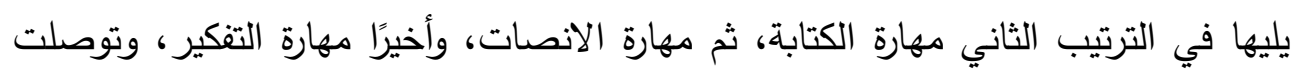

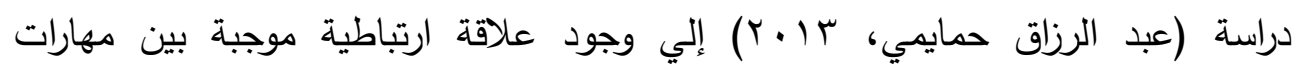

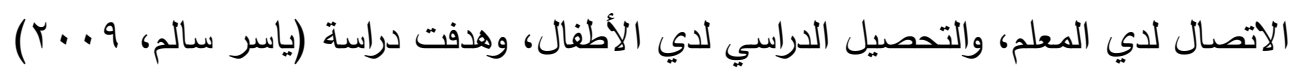


إلي تصميم استمارة استبيان للتعرف علي تطوير مهارات الاتصال الفعال لدي مدرسي التربية الرياضية بمصر كإجراء لتحسين العملية التعليمية.

\section{r - مهارة ادارة الوقت:}

الوقت من النعم التي أنعم الله بها علينا، وهو من النعم التي يغفل عنها الناس، ولا

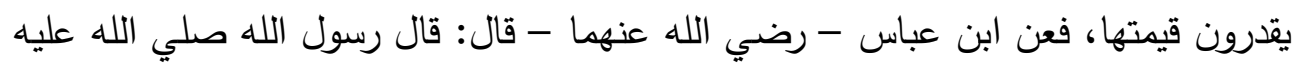

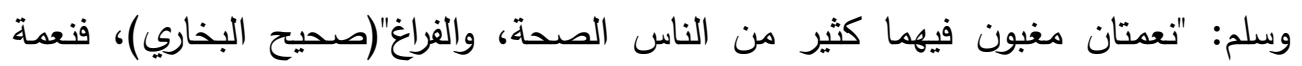

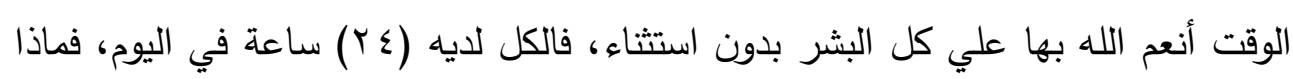

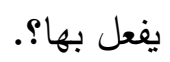

ويعد الوقت من الموارد الهامة للإفراد والمؤسسات، بل أكثر الموارد حيوية، فهو لا يعوض بأي الأثمان، ولا يستبدل بأي قيم، ولا يشتري بأي مكنون، ويتسم بالجمود فلا يمكن

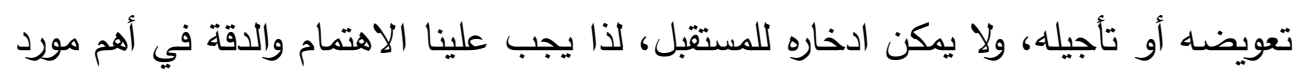

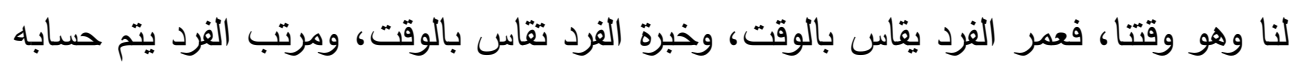
بالوقت.

ومن علامات نجاح معلمة الروضة محافظتها علي الوقت، واستخدامه بطرق

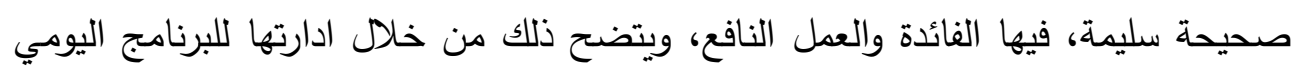

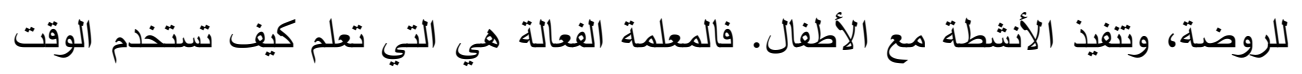

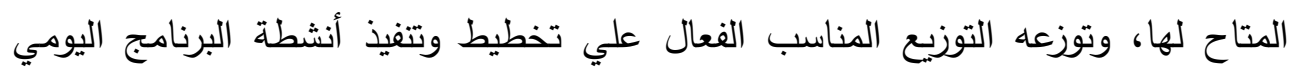

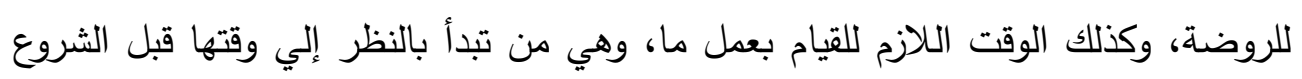
في مهامها وأعمالها.

\section{مفهوم إدارة الوقت: - مفت}

هي علم وفن الاستخدام الرشيد للوقت، واستثمار الزمن بشكل فعال، وهي عملية

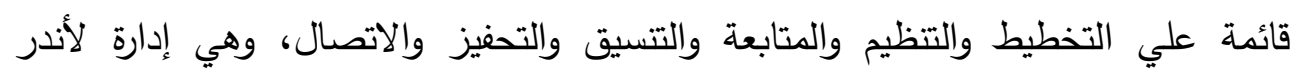


عنصر متاح للمشروع، فإذا لم نحسن ادارته فإننا لن نحسن إدارة أي شيء (خالد المومني، $.(1),+.0$

وتعرف إدارة الوقت أنها عملية الأستفادة من الوقت المتاح والمواهب الشخصية

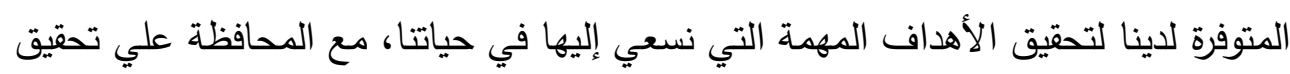
التوازن بين متطلبات العمل والحياة الخاصة، وبين حاجات الجسد والروح والعقل(إبراهيم

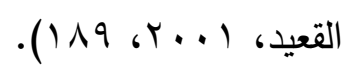

وتعني أيضًا إدارة الذات، وإدارة شؤون الوظيفة بما يكفل الحصول علي النتائج

$$
\text { المحدة في الوقت المتاح (السيد عليوة، ب. . بـ، ع ( ). }
$$

ويقصد بتنظيم وإدارة الوقت، الإستخدام الأمثل والكفه للموارد المتاحة داخل وخارج

الروضة بما فيها الوقت، وتوظيف معلمة الروضة لمواهبها ومهاراتها الثخصية بالأسلوب

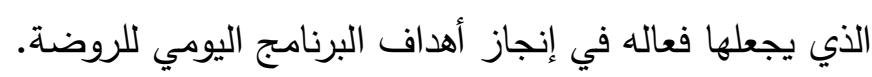

\section{أهمية إدارة الوقت:}

الوقت من أهم النعم التي أنعم بها الله علينا، ولأهميته أقسم الله في القرآن الكريم به

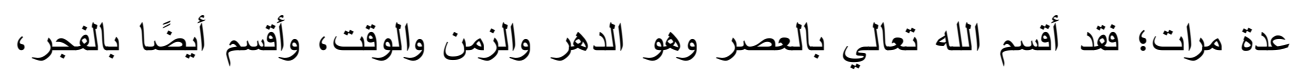
والضحي، والليل، وفي ذلك دلالة علي عظم هذا العنصر وشرفه، وأهمية استغلاله.

ورصيد الإنسان من الوقت لا يتضاعف بل ينقص عكس الأرصدة الأخري كالمال

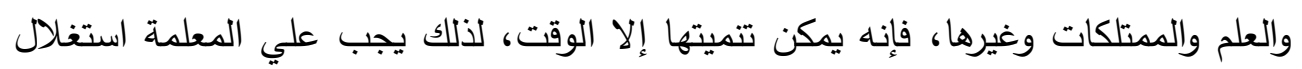

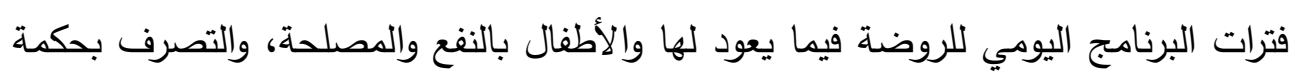

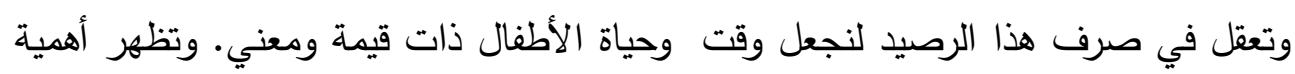

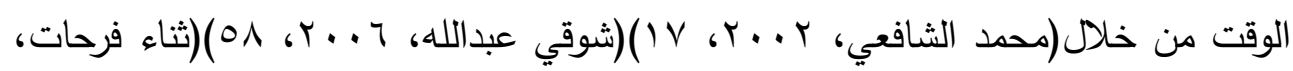

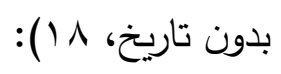

انجاز أهداف البرنامج اليومي للروضة، التخفيف من الضغوط التي تواجه المعلمة

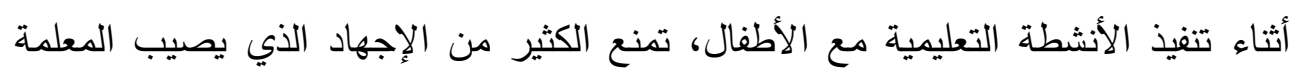


والأطفال أثناء البرنامج اليومي، تحسين نوعية التعليم في الروضة، تحقيق نتائج أفضل، زيادة سرعة انجاز الأنشطة والأعمال المكلف بها الطفل مما يعود بالنفع عليه وعلي زملائه، تقليل الأخطاء أثناء ممارسة الطفل للأنشطة، تحقيق التوازن بين حاجات الطفل المختلفة والمتنوعة، تزيد من قدرة المعلمة والطفل علي المرونة والتركيز، وتسمح بظهور الأفكار لتوني الأبداعية من قبل الأطفال.

وفي حدود علم الباحث لا توجد دراسة تتاولت تتمية مهارة ادارة الوقت لدي معلمة

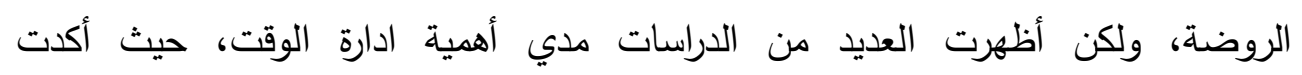

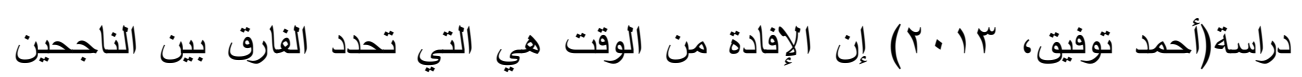
والفاشلين في هذه الحياة، وأن الاستخدام السليم للوقت يبين الفرق بين الإنجاز والإخفاق،

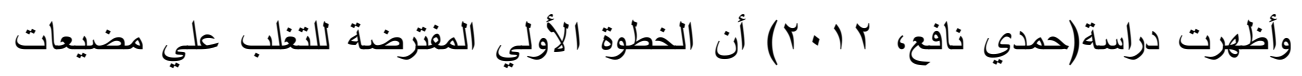

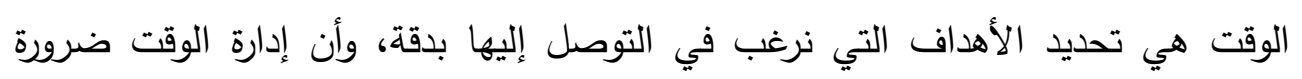

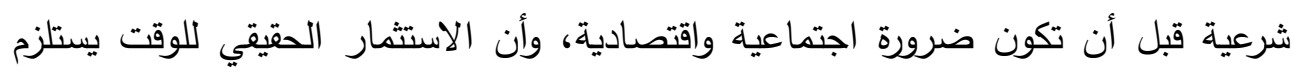

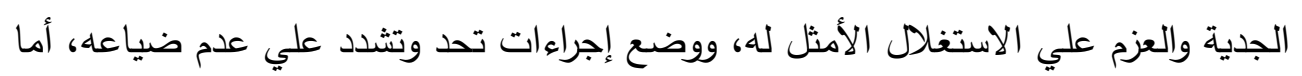

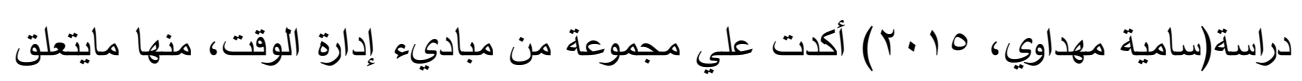
بالتخطيط، ومنها مايتعلق بالتنظيم، ومنها مايتعلق بالرقابة.

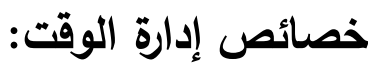

لإدارة الوقت مجموعة من الخصائص يمكن حصرها فيما يلي(شوقي عبدالله،

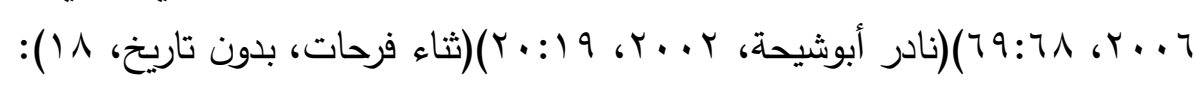

إنجاز المعلمة لأهداف البرنامج اليومي، والمهام الموكله إليها في الأوقات المحددة،

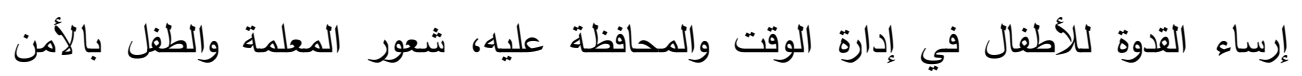

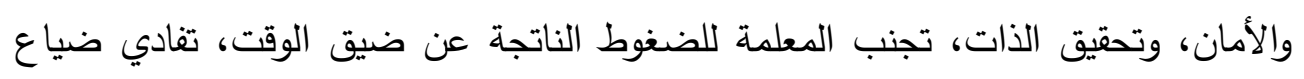

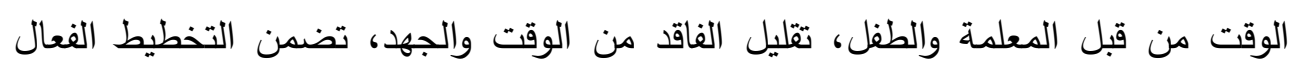
للأنشطة التي يمارسها الطفل علي مدار اليوم أو الأسبوع. 


\section{أنواع إدارة الوقت:}

تعددت تقسيمات الباحثين لأنواع الوقت، ومن أبرزها تقسيمه إلي أربعة أنواع هي

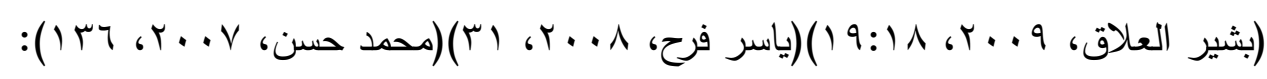
*الوقت الإبداعي: وهو وقت تخصصه معلمة الروضة للتخطيط المستقبلي، والتفكير والتأمل، وتتظيم العمل، وتثقييم الإنجازات.

*الوقت التحضيري: ويمثل الفترة الزمنية التحضيرية التي توظفها المعلمة في تخطيط الأنشطة، حيث يتم فيها جمع المعلومات والحقائق، وتجهيز بيئة التعلم، بحيث يمكن انجاز الأنشطة بأقل تكلفة في الجهد والوقت.

*الوقت الإنتاجي: ويمثل الفترة الزمنية التي تستغرق في تنفيذ الأعمال والأنشطة التي تم التخطيط لها في الوقت الإبداعي، والتحضير لها في الوقت التحضيري من قبل معلمة

الروضة.

*الوقت غير المباشر أو العام: ويخصص عادة للقيام بنشاطات ثانوية ذات طابع عام.

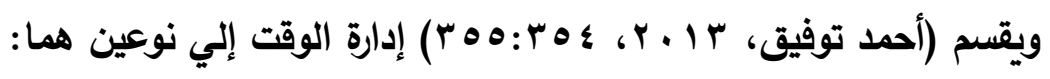

أ) إدارة وقت الأفراد: وتعني تدريب الأفراد علي استخدام أفضل الإمكانيات، والوسائل المتاحة لزيادة الإنتاجية، ورفع معدلات الأداء، وتقليل الوقت الضائع إلي حدوده الدنيا. ب) إدارة وقت المؤسسات: المؤسسة الناجحة هي التي تقوم بعملية تحليل الوقت، وذلك بتحديد كل أنواع الأنشطة التي تتم داخل المؤسسة.

\section{معوقات إدارة الوقت: - مع}

هناك عدة معوقات تواجه معلمة الروضة في إدارة الوقت لعل أهمها ما

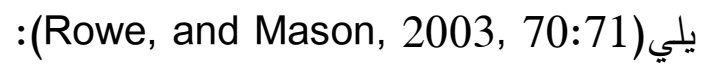

أهداف النشاط غير واضحة ومحددة، وغير واقعية، وغير قابلة للقياس، الخطة

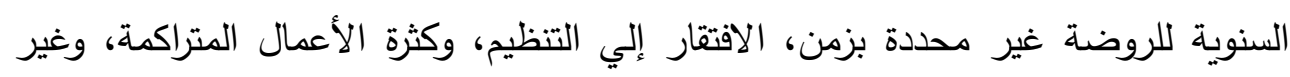


المنتهية، الافتقار إلي تتظيم سليم للأوراق والملفات الخاصة بالأطفال، عدم وجود أولويات للمهام المطلوب انجازها من قبل المعلمة والأطفال، التسويف والتردد في اتخاذ القرار، تراكم أكثر من عمل في وقت واحد، إعطاء العمل البسيط فوق ما يستحق من الوقت والجهد، ومن

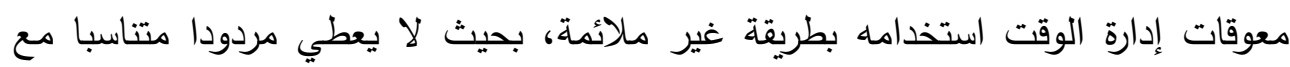

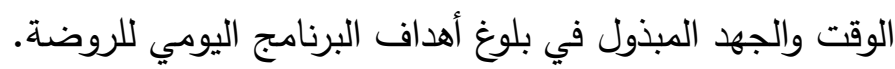

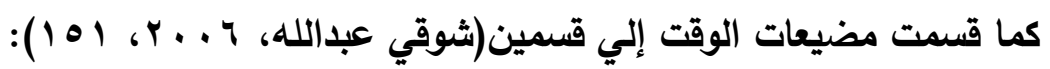
أ) مضيعات خارجية: ومصدرها أولياء أمور الأطفال، والزوار ، أو مستلزمات العمل

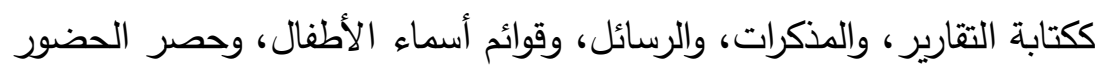
والغياب، من قبل معلمة الروضة. ب) مضيعات داخلية: مصدرها المعلمة نفسها؛ أي منبعثة من ذاتها، وتتضمن في العادة الاجتماعات، وضعف التخطيط، والتسويف، وتأجيل العمل، وعدم القدرة علي قول لا، وعدم الشعور بالمسؤولية، وضعف الرقابة الذاتية.

ومن معوقات ومضيعات الوقت أيضًا: استخدام المعلمة للهاتف داخل قاعة النشاط،

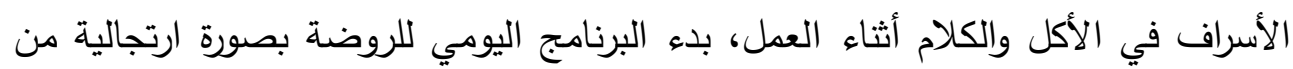

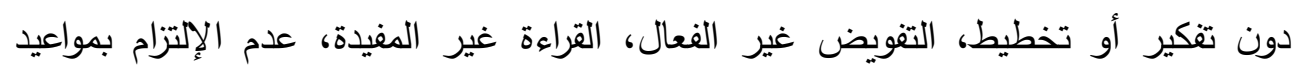

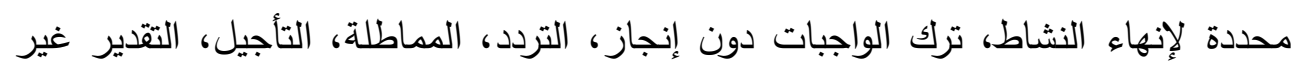

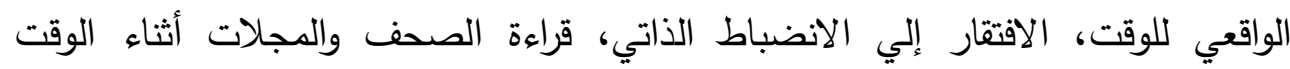
المخصص لأنشطة الأطفال، عدم تحديد الأهداف المراد انجازها(يومية، اسبوعية، شهرية)، عدم تحديد المهام المطلوب انجازها خلال ساعات العمل.

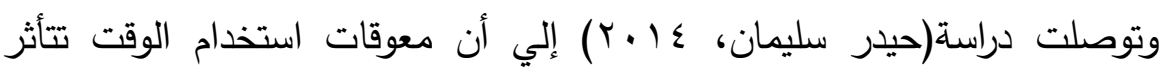
بجميع المتغيرات الشخصية والوظيفية مثل: سنوات الخبرة، والمنصب الإداري، والدرجة الوظيفية، كما أوصت بتدريب المعلمات وتزويدهم بالمعارف والمهارات اللازمة لإدارة الوقت ولت ولتهيك بالطريقة المثلي. 


\section{سبل التغلب علي مضيعات الوقت:}

التحليل الدقيق للأنشطة والمهام التي تقوم بها معلمة الروضة هو المدخل الأفضل

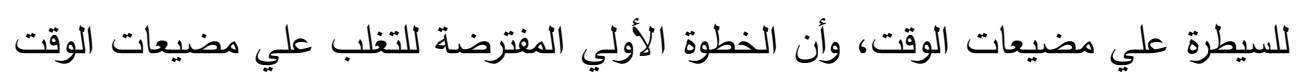

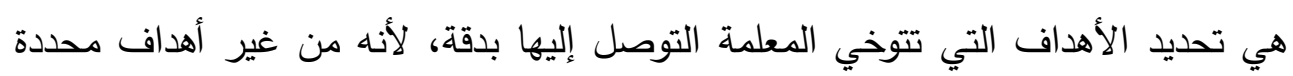

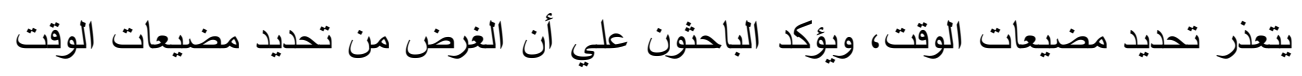

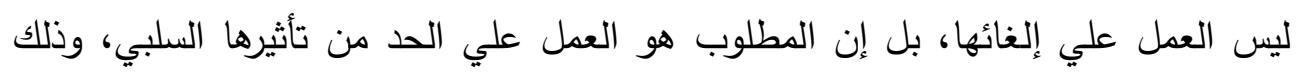

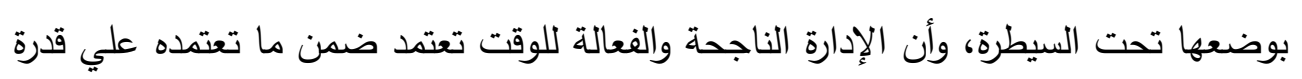

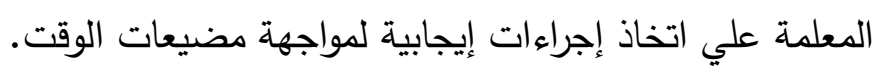

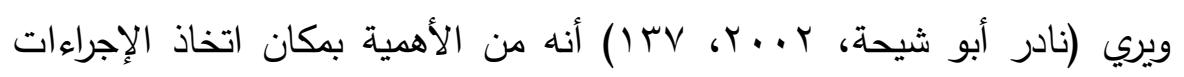

$$
\text { الآتية للتغلب على مضيعات الوقت: }
$$

- تحديد مشكلة إدارة الوقت: حيث أن المشكلة هي ضعف استشعار المعلمة أحيانا

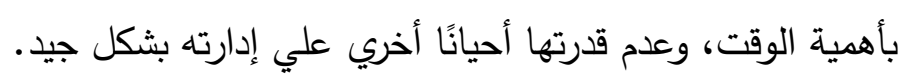

- إيجاد آلية للتعامل مع مضيعات الوقت: وذلك من خلال التخطيط والتتظيم المناسب

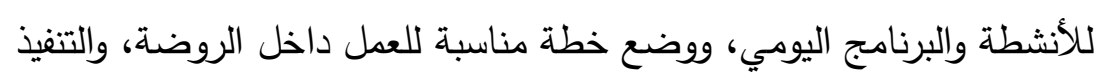
المتقن للخطة، واتخاذ إجراءات إيجابية تجاه مضيعات الوقت ولتهن

وهناك مجموعة من المهارات التي تساعد وتمكن معلمة الروضة من التخلص من

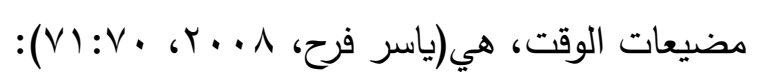

- التخطيط: إذ يجب علي المعلمة أن تتظر إلي قائمة أهدافها الأسبوعية - التي خطط

$$
\text { لها مسبقًا - كل يوم. لون. }
$$

- التركيز: قد يكون من الصعب فعل أثياء كثيرة في يوم واحد، لذا علي المعلمة أن

$$
\text { تهنم بإنجاز شيء واحد فقط في كل مرة. }
$$

- الاسترخاء : خلال أوقات الراحة علي المعلمة ألا تفعل شيئا سوي الاسترخاء مع

$$
\text { ممارسة بعض التمارين الرياضية. }
$$


- تجنب التشوش والارتباك: وذلك بتصنيف المعلمة لأعمالها أو حاجاتها الشخصية. - عدم الخوف من قول لا: للمعلمة الحق في قول (لا) دون شعور بالذنب. - التظلب علي التأجيل والمماطلة: وذلك سيولد لدي المعلمة عادات جديدة. ومن الدراسات والأدبيات التي توصلت إلي المهارات التي تساعد وتمكن المعلمة من

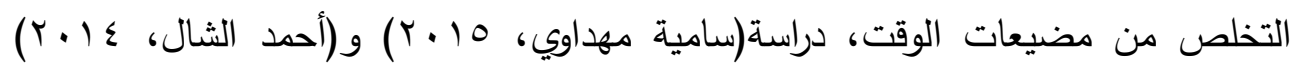

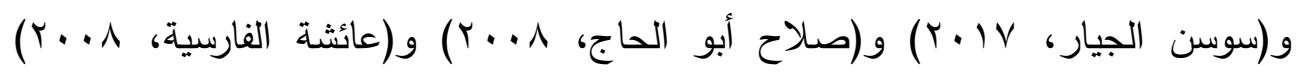

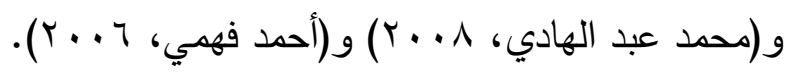

وعلي معلمة الروضة مراجعة وقتها باستمرار، استخدام أساليب مراجعة إدارة الوقت،

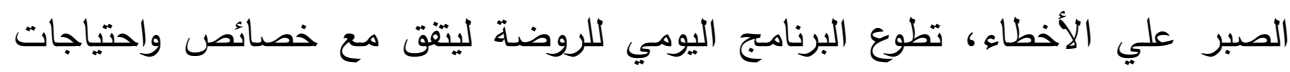
الأطفال، وتركز علي الأولويات.

\section{المحور الثاني: معلمة الروضة:}

بعد الاطلاع على محاور وثيقة معايير إعداد معلمة رياض الأطفال اتضح أن الوثيقة لم تشر إلى نواتج التعلم أو مواصفات الخريجة في المهارات الناعمة(الثخصية)، رغم أهمية كلا من المهارات الناعمة والصلبة عند التقدم بطلب لوظيفة ما، وبينما تكون المهارات الصلبة هي سبب الحصول علي المقابلة فإن المهارات الناعمة هي السبب في الحصول علي الوظيفة، لأن أصحاب ومديري المدارس يبحثون عن المعلمين القادرين علي تأدية عدة

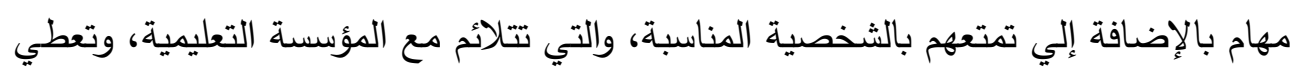
انطباع جيد عنها لأولياء الأمور ، وهذا ما أكدت عليه الدراسات السابقة، كما أن المهارات

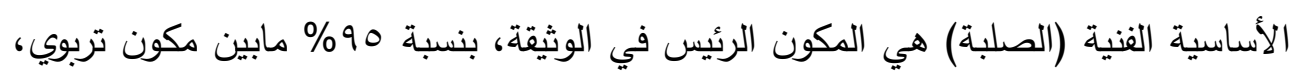

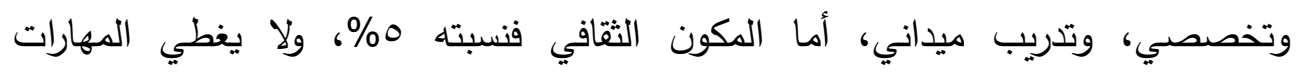

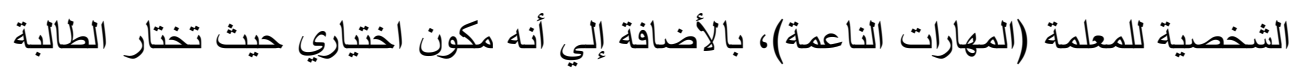

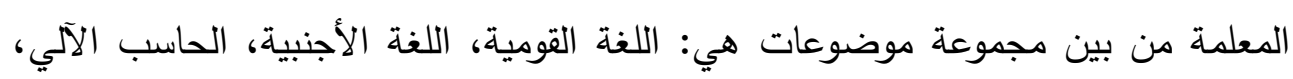
المعرفة بالتاريخ القومي والعالمي، تشريعات ومنظمات الطفولة، أمن وسلامة الطفل، الثقافة العلمية والحياتية، المشاركة المجتمية، ومن هنا تأتي أهمية الدراسة الحالية التي تهدف إلي 
تتمية بعض المهارات الناعمة لدي معلمة رياض الأطفال، حيث أن وثيقة معايير إعداد معلمة رياض الأطفال لا تغطي هذا الجانب.

\section{تدربب معلمة الروضة:}

تثير الأدبيات التربوية المعاصرة إلي وجود العديد من المفاهيم حول ماهية التتمية المهنية للمعلمين والتي تتداخل أو تستخدم كمترادفات لهذه العملية، ومنها: التدريب أثناء الخدمة، والتربية المستمرة، والتربية أثناء الخدمة، والنمو المهني، والتتمية المهنية، ولكن يمكن القول أن التدريب أثناء الخدمة، والتنمية المستدامة هما أكثر المفاهيم استخداما(ممدوح

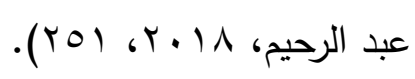

وتعتبر التتمية المستدامة للعاملين في الحقل التربوي مدخلاً مهماً وأساسياً من التهاً

مدخلات جودة العملية التعليمية، حيث أنها تعني بتحسين أداء القائمين بالتدريس وتجعلهين فئرئ قادرين على القيام بأدوارهم التعليمية ومتطلبات عملهم بكفاءة وفاعلية.

وقد أصبحت الحاجة الى التدريب حاجة قائمة باستمرار نظراً لأن المعلم بصفة

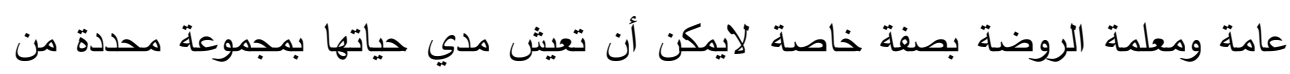
المعارف والمهارات، فتحت ضغط الحاجات الداخلية والتقدم الهائل والاتجاه نحو الجودة فإن لهان هذا الأمر يتطلب ضرورة أن تحافظ معلمة الروضة على مستوي متجدد من المعلومات

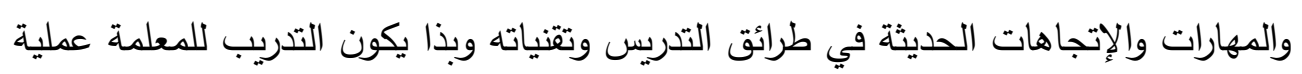
نمو مستمرة ومتواصلة.

وتقوم معلمة الروضة بتوفير مناخ إيجابي داخل غرفة النشاط من خلال قيامها بعدة

إجراءات يتمثل بعضها في التزود باستراتيجيات تشتمل علي مهارات الأتصال، والعلاقات

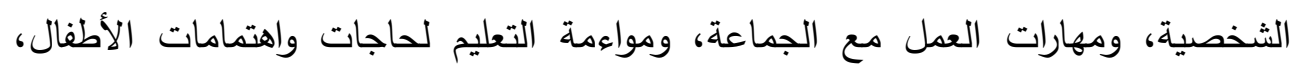

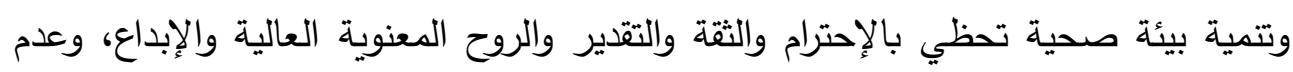
التهديد، واستخدام بعض الأنشطة التعليمية ذات الصلة الوثيقة باهتمامات وتحديات الأطفال

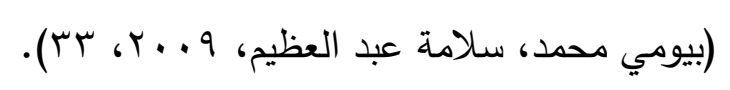


ومعلمة الروضة تؤدي دوراً هاماً ومؤثراً في تشكيل شخصية الطفل فلابد أن يكون

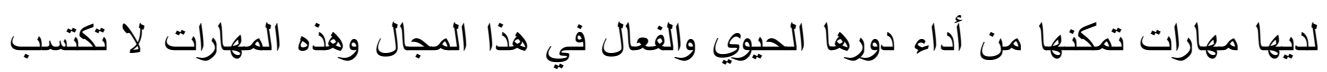
بالصدفة بل يجب أن يتم ذلك من خلال سلسلة متكاملة وشاملة من برامج التدريب المستمرة التي تعتمد علي التخطيط العلمي والتناسق المنهجي، ويجب أن ترتبط هذه البرامج بالمشكلات اليومية التي تواجهها المعلمة في عملها إضافة إلي استثمارها للمستجدات في جوانب عملية التعليم والتعلم في ضوء معايير توجه ممارستها التربوية داخل رياض الأطفال وتعمل علي

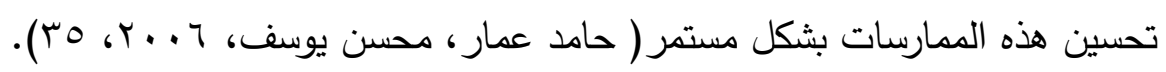
ويستهاف تدريب المعلم أثناء الخدمة تحقيق اربعة أهداف هى: 1- اضافة معارف مهنية جديدة الى المعلمين. r- - ت بتمية المهارات المهنية لديهم. r- تتمية وتأكيد القيم المهنية الداعمة لسلوكهم.

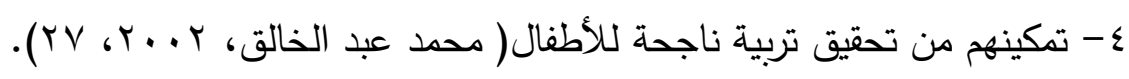
إلى جانب ذلك فإن تدربب المعلمة أثناء الخدمة يعمل على: - - تحسين النمو المهني للمعلمة. - العمل على تأهيلها وتدريبها وتطوير كفاياتها المهنية. - - رفع انتاجيتها وتعزيز ثقتها بنفسها. - - التعرف على حاجاتها المهنية. وخطط التدريب التي تبني في ضوه الإحتياجات الفعلية للمعلمين تكون ملبية

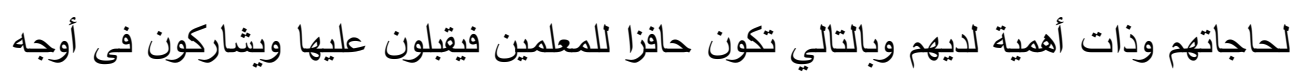

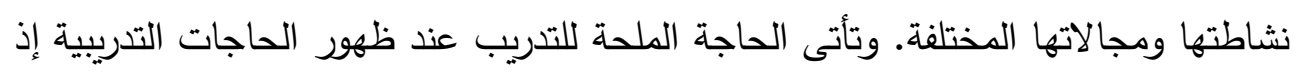
يتوقع من التدريب التربوى أن يلبى هذه الحاجات بالبرامج التدريبية الدكثفة أو الموزعة التهات التهات

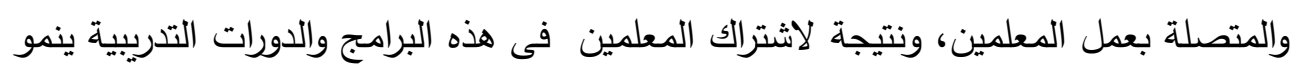


المعلم مهنيا فى الكفايات العامة والكفايات والمهارات المتعلقة بتخصصه لاسيما اذا جاءت

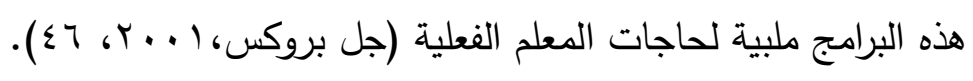

وأفادت الدراسات السابقة أن التتمية المستدامة من المككن أن تطور أداء المعلمين

فى جميع الجوانب حتى العلاقات فيما بينهم، مثل دراسة(Dorothy Bed Ford,2008)، دراسة(Melinda Bonsall,1999,p2)، والتى ساعدت على تتمية مهارات العمل الجماعى دئى وحل المشكلات لاى المعلمين، ودراسة (Kevin Jones and Others,1999) التى ساعدت على تتمية مهارات المعلم فى استخدام استرتيجيات ادارة السلوك ومنع حدوث

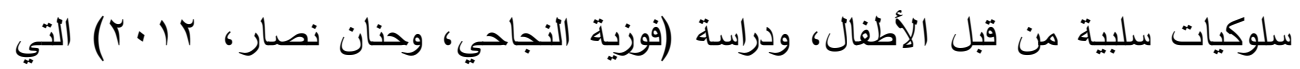

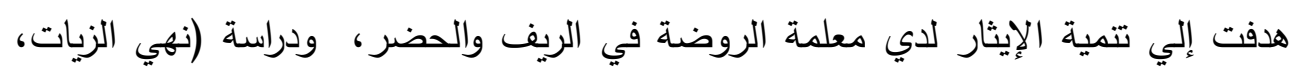

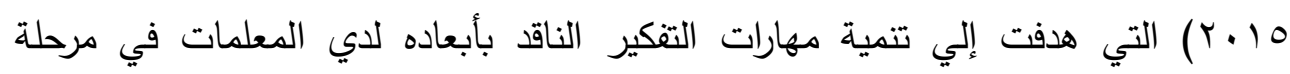
الروضة باستخدام برنامج الكورت، ودراسة (Vasudevan, 2015)، التي هدفت إلي تتمية مهارات التحليل وحل المشكلات الإبداعية لدي معلمات ما قبل المدرسة باستخدام نظام الكورت لمهارات التفكير · ت مهات

كما أفادت الدراسات السابقة أن تدريب المعلمين أثناء الخدمة يساعد فى النمو

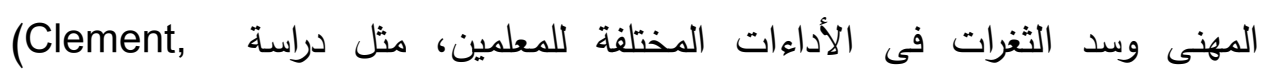

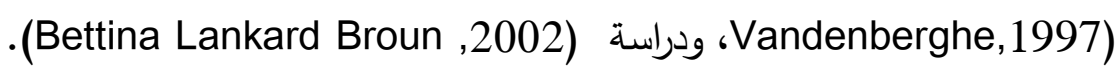
وأوضحت بعض الدراسات وجود قصور فى أداء معلمات الروضة، وأكدت على

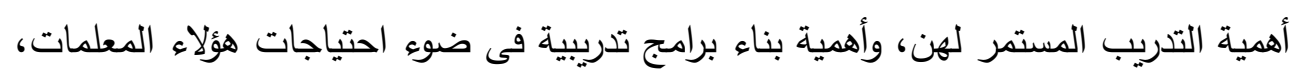

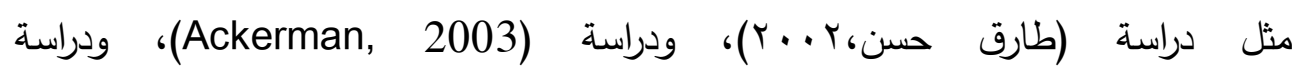

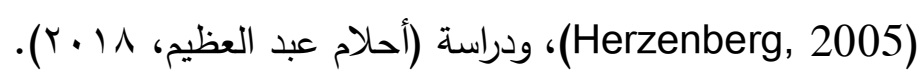

واهتمت دراسات تدريب معلمات رياض الأطفال، مثل دراسة(جيهان جودة،

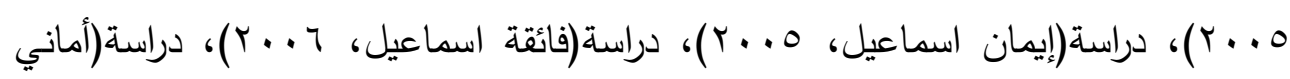

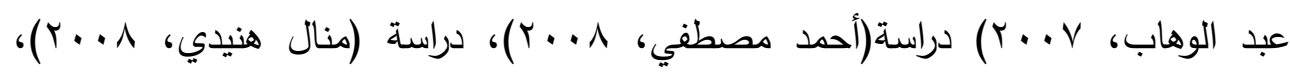

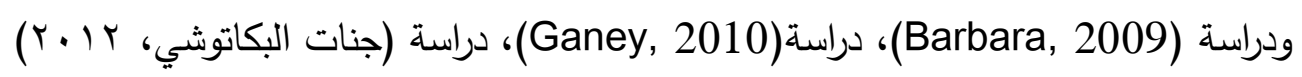


بتدريب معلمات الروضة علي مهارات فنية، موسيقية، حركية، مهارات تصميم وإنتاج البرمجية التعليمية للطفل، تخطيط الأنشطة وتتفيذها، إدارة غرفة النشاط، كيفية اختيار

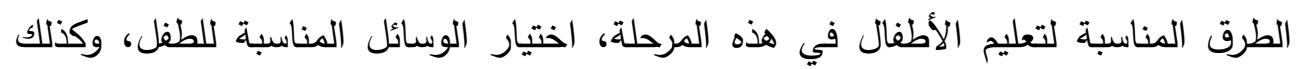

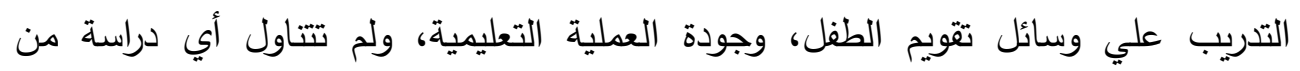
الدراسات السابقة - في حدود علم الباحث - تتمية المهارات الناعمة لدي معلمات الروضة.

\section{الدراسة الميدانية}

يتناول هذا الجزء من البحث إعداد البرنامج التدريبي، وإعداد أدوات البحث،

وتطبيقها، وتطبيق البرنامج على عينة البحث.

$$
\text { أولاً: إعداد أدوات البحث: }
$$

1 - قائمة المهارات الناعمة لمعلمة الروضة:

أ. الههف من إعداد القائمة: تحديد المهارات الناعمة المناسبة لمعلمة الروضة، وذلك بهدف: اعداد برنامج تدريبي يتضمن بعض هذه إعضداد المهارات لتدريب معلمات

$$
\text { الروضة- عينة البحث - عليها. }
$$

ب ـ المصادر التي اعتمد عليها في اشتقاق قائمة المهارات الناعمة:

- - البحوث والدراسات والمراجع التي اهتمت بتنمية المهارات الناعمة: دراسة

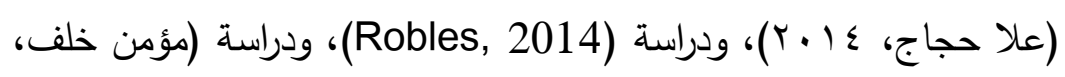

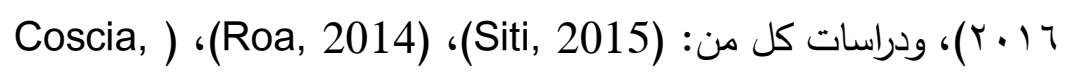

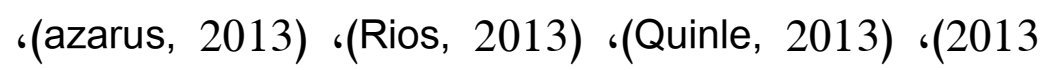

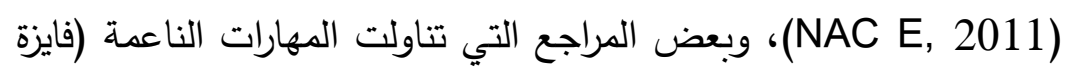

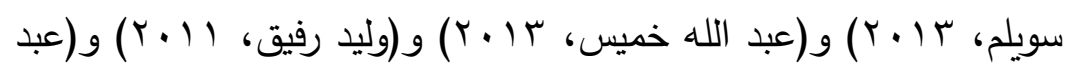

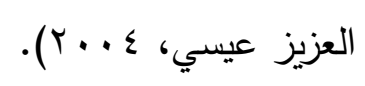

- - بعد الانتهاء من اشتقاق المهارات الناعمة من مصادرها المختلفة، وبناء قائمة للمهارات الناعمة لمعلمة الروضة، والاستفادة من المراجع، والدراسات 
السابقة في إعداد قائمة شاملة للمهارات الناعمة، تحتوي علي (ع) مهارات رئيسية يندرج تحتها(Y) مهارة فرعية. وقد جاءت المهارات مرتبطة

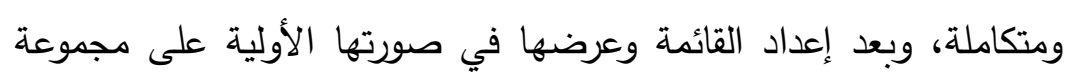

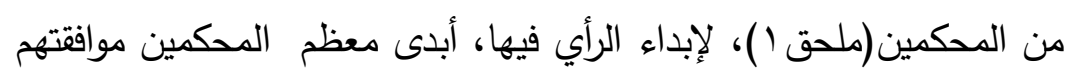

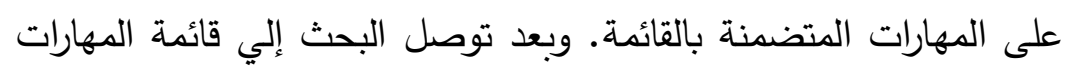

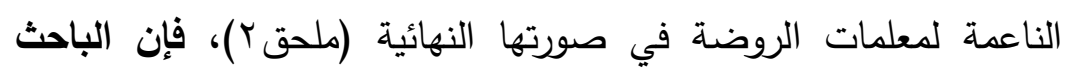

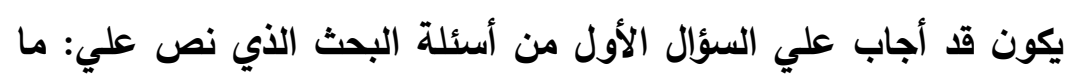

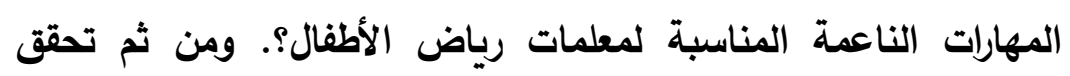

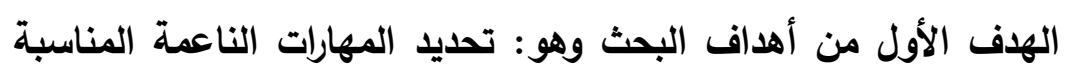

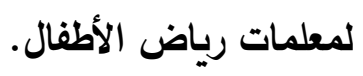
r - بطاقة ملاحظة أداء معلمة الروضة:

كان الهدف من البطاقة ملاحظة أداء معلمات الروضة أثناء ممارسة عملهن بالروضة بغرض تعرف مدى ما طرأ من تحسن على أدائهن في مهارتي من المهارات الناعمة (مهارة لغة الجسد- مهارة إدارة الوقت) نتيجة لمرورهن بالبن بالبرنامج التدريبي، وللتأكد من صلاحية البطاقة للاستخدام، قام الباحث بالإجراءات التالية: أ- صياغة بنود البطاقة:

صيغت بنود البطاقة بصورة إجرائية في عبارات مباشرة تصف الأداء المهاري

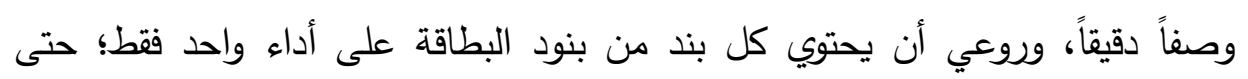
يمكن ملاحظته بسهولة، وجاءت العبارات كلها مثبتة.

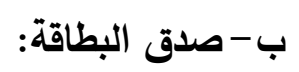

تم تحليل المهارات المراد قياسها لدى المعلمات إلى مجموعة من المهارات الفرعية المرتبطة بالمهارة الرئيسة، ثم عرضت البطاقة على مجموعة من المحكمين(ملحق ()،

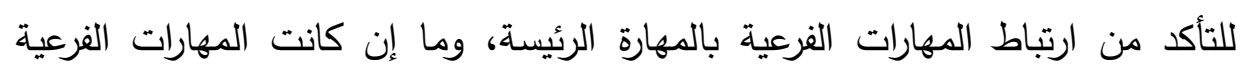

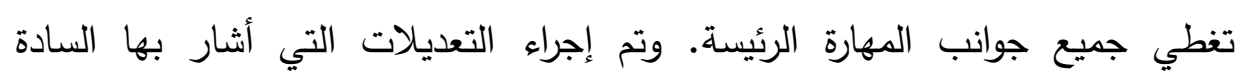


الهحكمون، واستبعدت الأداءات التي قلت نسبة الاتفاق حولها عن ^^\%، وتكونت

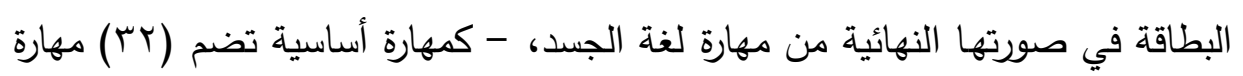
فرعية- ومهارة إدارة الوقت - كمهارة أساسية تضم (10) مهارة فرعية-، وبذلك يكون

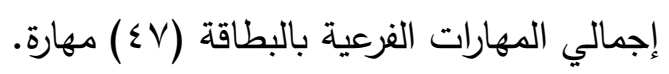

\section{ج- ثبات بطاقة الملاحظة:}

حُسب ثبات البطاقة عن طريق ثبات الملاحظين؛ حيث قام الباحث- بمساعدة اثتنين من مشرفات الروضة- بملاحظة سلوك ست معلمات أثناء تتفيذهن البرنامج

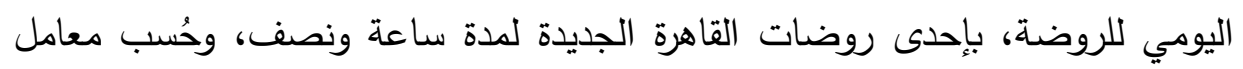

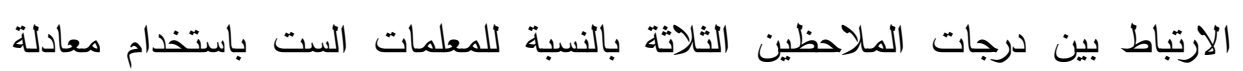

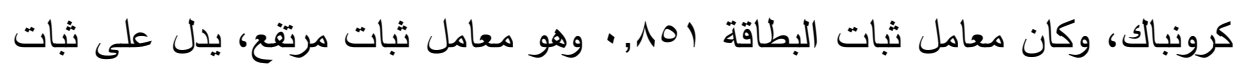
البطاقة.

التقدير الكمي لأداء المعلمات:

حدد الباحث ثلاثة مستويات لمدى وجود السلوك المراد قياسه لدى المعلمات

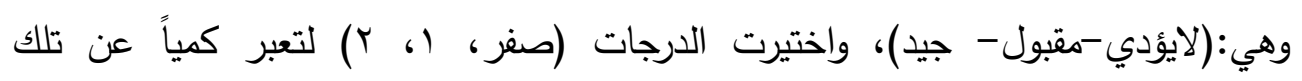

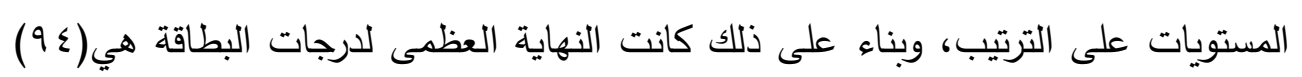

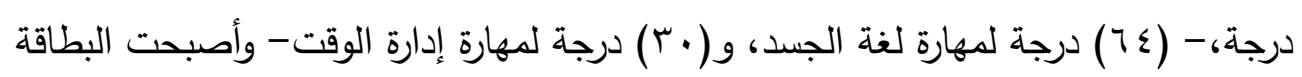

صالحة للتطبيق ملحق (r).

r- الأختبار التحصيلي لمعلمات الروضة(ملحق \&):

تم إعداد اختبار تحصيلي بهدف قياس مهارتي من المهارات الناعمة هما: مهارة

لغة الجسد، ومهارة إدارة الوقت، مكون من 00 سؤال.

ضبط الاختبار:

تم ضبط الاختبار التحصيلي من خلال عمليتى قياس الصدق والثبات كما يلى: 
قياس صدق الاختبار: تم عرض الاختبار مع قائمة المهارات الناعمة، وبطاقة

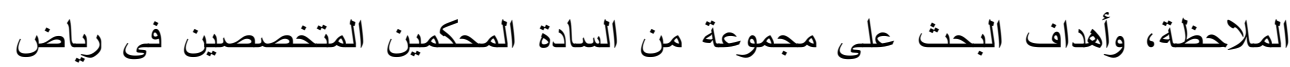
الأطفال، والمناهج، وعلم النفس، وتم تعديل الاختبار فى ضوه الماف الملاحظات التى أبداها

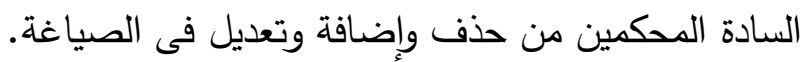

قياس ثبات الاختبار: تم قياس ثبات الاختبار من خلال تطبيقه على عينة من

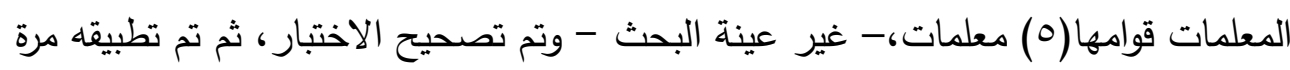
أخرى على نفس العينة بعد أسبوعين من التطبيق الأول، وتم تصحيحه، وبحساب معامل

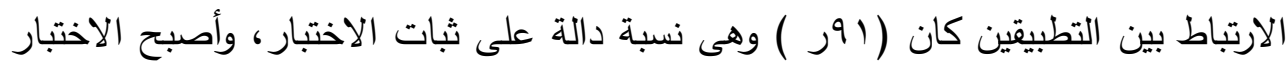
صالح للتطبيق. الصورة النهائية للأختبار: - n

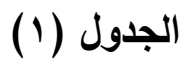

\begin{tabular}{|c|c|c|c|}
\hline المجموع & ادارة الوقت & لغة الجسد & نوع السؤال \\
\hline 10 & v & $\wedge$ & أولاً: ضع دائرة حول الأجابة الصحيحة \\
\hline$r$. & 11 & 9 & ثانياً: ضع علامة صح أو خطأ أمام العبارات التالية \\
\hline$r \cdot$ & 1. & $1 \cdot$ & ثالثاً:أكمل العبارات التالية \\
\hline هـ سؤال & ^ זسؤال & VY V V V & المجموع \\
\hline
\end{tabular}

؛ - البرنامج التدريبي لمعلمات الروضة:

بعد التوصل إلى قائمة المهارات الناعمة الرئيسة والفرعية، وتحديد مهاراتان فقط

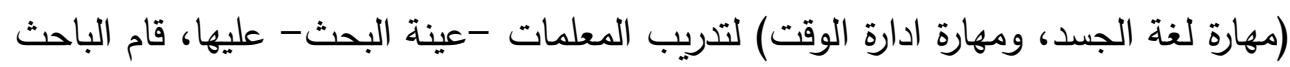
بتوصيف البرنامج وفلسفته وتحديد أهدافه، أسس بناء البرنامج، ومن ثم اختيار المحتوى العلمي الذي يحقق تلك الأهداف، عدد المتدربات، زمن التدريب، أساليب التدريب، القائم بالتدريب، مكان التدريب، معينات التدريب، أساليب التقويم، توزيع جلسات البرنامج، وأخيراً تتفيذ جلسات البرنامج، وتكون البرنامج في صورته النهائية من مجموعة من الأنشطة؛

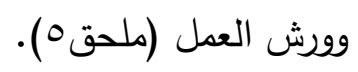




\section{ثانياً: تطبيق البرنامـج على عينة البحث:

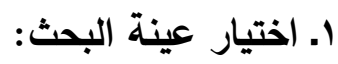

اختيرت عينة البحث بطريقة عشوائية من معلمات الروضة، وكان قوامها (•؛)

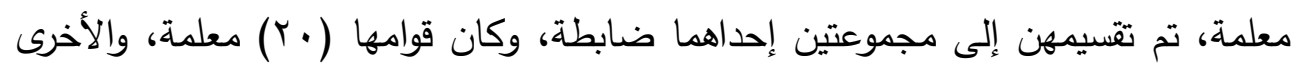

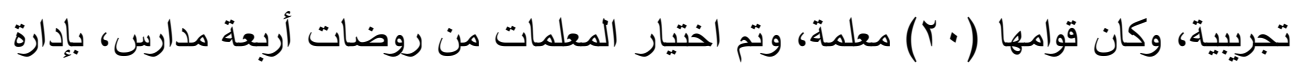

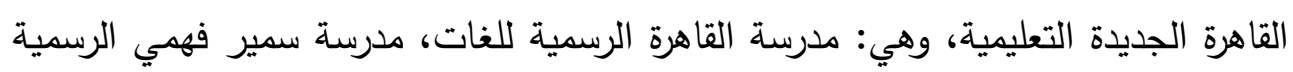

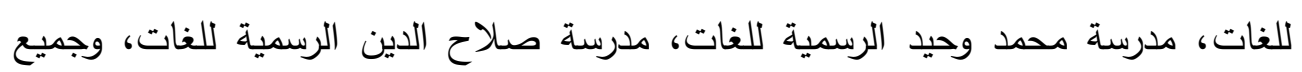
المعلمات عينة البحث خريجي شعب وكليات رياض الأطفال، وتتراوح سنوات الخبرة لديهن

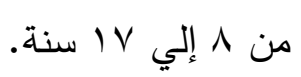

ويرجع سبب اختيار الباحث لتلك الروضات إلي:

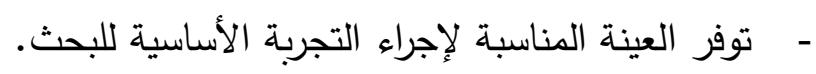

- توفر معامل الوسائط المتعددة بتلك الروضات المتوفر بها العديد من الأجهزة اللازمة لإجراء التجربة. - ق قناعة الأدارة ومعلمات الروضة بأهمية وطبيعة البحث. - قيام الباحث بالإشراف على مجموعتين من طالبات الفرقتين الثالثة والرابعة في مادة التربية العملية؛ مما سهل عليه الكثير من الأمور عند تتفيذ تجربة البحث. - العلاقات الطيبة بين الباحث وإدارات الروضات، والمعلمات؛ مما ساعد على التقليل

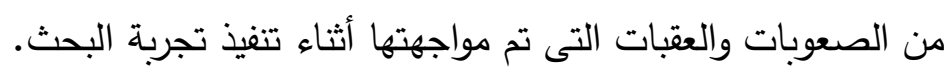
r. التطبيق القبلي لأدوات البحث:

\section{أ. تطبيق قائمة المهارات الناعمة لمعلمة الروضة:}

قام الباحث بتطبيق استبيان علي معلمات رياض الأطفال -عينة البحث- بهدف

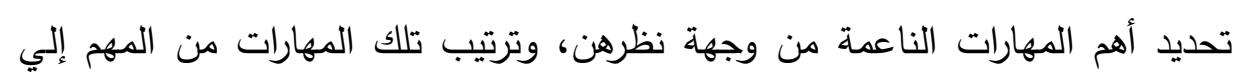




\section{أ.م.د/ سعيد عبد المعز على موسي}

الأقل أهمية، والجدول التالي يوضح المتوسطات والنسب المئوية للمهارات الناعمة مرتبة تتازلياً.

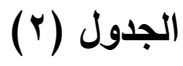

المتوسطات والنسب المئوية للمهارات الناعمة مرتبة تنازليا

\begin{tabular}{|c|c|c|c|c|}
\hline \multicolumn{3}{|c|}{ النسبة المئوية } & \multirow[t]{2}{*}{ المهارات الناعمة } & \\
\hline 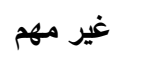 & مهم مج & 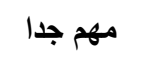 & & \\
\hline- & $\% \backslash \leq, r$ & $\% \wedge \bullet, \vee$ & مهارات التواصل الفعال & 1 \\
\hline- & $\% 1 \leq, r$ & $\% \wedge \bullet, \vee$ & العل في فريق & r \\
\hline- & $\% 1 \leq, r$ & $\% \wedge \bullet, \vee$ & إدارة الوقت & $r$ \\
\hline- & $\% \backslash \leqslant, r$ & $\% \wedge \bullet, \vee$ & المرونة & $\varepsilon$ \\
\hline- & $\%$ \% l, & $\% \vee \wedge, \uparrow$ & التشبيك (اقامة علاقات & 0 \\
\hline- & $\%$ \%,$\varepsilon$ & $\% \vee \wedge, \uparrow$ & حل المشكلات & 1 \\
\hline- & $\%$ \% l, & $\% \vee \wedge, \uparrow$ & ضبط النفس & $\mathrm{v}$ \\
\hline- & $\%$ \% $1, \varepsilon$ & $\% \vee \wedge, \uparrow$ & الثقة بالنفس & $\wedge$ \\
\hline- & $\%$ \% l, & $\% \vee \wedge, \uparrow$ & الأبتكار & 9 \\
\hline- & $\%$ \%४, & $\% \vee 1, \varepsilon$ & اتخاذ القراد & 1. \\
\hline$\% \vee, 1 \leq$ & $\%$ \% $1, \leqslant r$ & $\% \vee ।, \varepsilon r$ & التأقلم & 11 \\
\hline- & $\% \curlyvee \wedge, \uparrow$ & $\% \vee 1, \varepsilon$ & 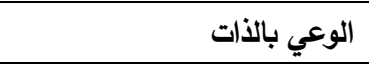 & ir \\
\hline- & $\%$ \%४, & $\% \vee 1, \varepsilon$ & التأثير والإقناع & ir \\
\hline- & $\% r \Delta, v$ & $\%$ \% & التعامل مع المواقف الصعبة & $1 \leq$ \\
\hline- & $\%$ \% ०, v & $\% ч \varepsilon, r$ & تحفيز النفس & 10 \\
\hline$\% \backslash \leqslant, r$ & $\% \curlyvee \wedge, \uparrow$ & $\% \circ \vee, 1$ & التفاوض & 17 \\
\hline- & $\%\{r, \wedge \uparrow$ & $\% \odot v, 1 \leq$ & القيادة & iv \\
\hline$\%$ \% $1, \leqslant r$ & $\%$ Y $1,\{r$ & $\% \circ \vee, 1 \leq$ & المبادأة & 11 \\
\hline- & $\% \leqslant r, \wedge \uparrow$ & $\% \odot \vee, 1 \leq$ & مهارات التفكير الناقد & 19 \\
\hline- & $\% \vee 1, \&$ & $\%$ \%^, & التعامل مع الثخصيات الصعبة & $r$. \\
\hline- & $\% \vee 1, \varepsilon$ & $\% \curlyvee \wedge, \uparrow$ & إدارة الاجتماعات & r \\
\hline- & $\% \vee 1, \varepsilon$ & $\% \curlyvee \wedge, \uparrow$ & إدارة العواطف & $r r$ \\
\hline
\end{tabular}


يتضح من النتائج المبينة في الجدول(Y)، أن أهم المهارات من وجهة نظر

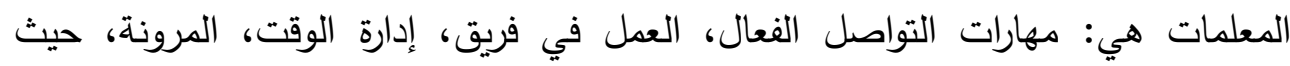

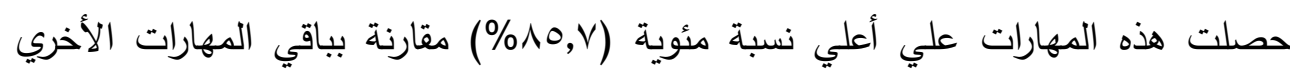
المتضمنة بالقائمة. وبذلك فإن الباحث يكون قد أجاب علي السؤال الثاني من أسئلة البحث

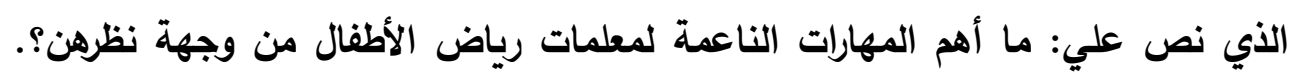

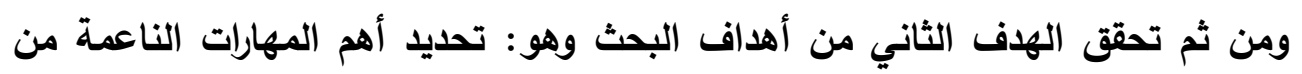
وجهة نظر معلمات رياض الأطفال. وسوف يتم تدريب معلمات الروضة افته عينة البحثعلي مهارتي فقط هما: لغة الجسد (وهي احدي مهارات التواصل الفعال)، وإدارة الوقت.

\section{ب. تطبيق بطاقة الملاحظة:}

قام الباحث بتطبيق بطاقة الملاحظة قبلياً على معلمات رياض الأطفال- عينة

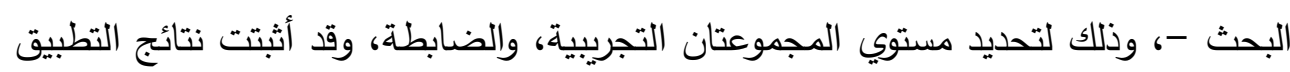

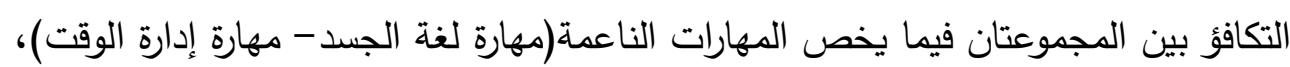

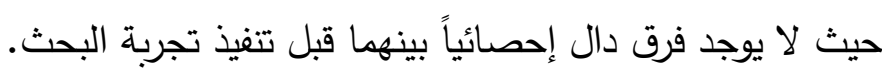
ج. تطبيق الأختبار التحصيلي:

تم تطبيق الأختبار التحصيلي قبلياً على معلمات رياض الأطفال- عينة البحث -، وذلك لتحديد مستوي المجموعتان التجريبية، والضابطة، وقد أثبتت نتائج التطبيق التكافؤ بين

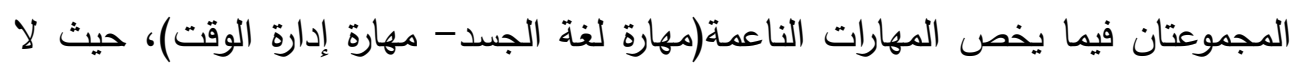
يوجد فرق دال إحصائياً بينهما قبل تتفيذ تجربة البحث.

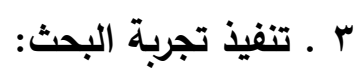

اجتمع الباحث مع معلمات الروضة أفراد عينة البحث، ووضح لهن الهدف من البرنامج، ثم أجاب عن تساؤلات المعلمات حول طبيعة البرنامج والغرض منه وكيفية تنفيذه، والمهام المطلوبة من المعلمات، والفائدة التي تعود عليهن من المشاركة في البرنامج، وتلى ذلك ذلك

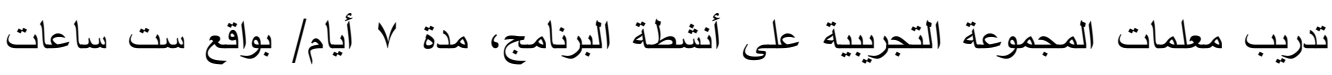
يومياً، إجمالي بـ ساعة. ومن ثم جمعت البيانات، وأجريت المعالجة الإحصائية لها. 
ع. التطبيق البعدي لأدوات البحث:

تم تطبيق بطاقة الملاحظة، والأختبار التحصيلي بعدياً على المجموعتين الضابطة والتجريبية، وتم تفريغ درجات كل معلمة على حده، ومن ثم جمعت البيانات، وأجريت المعالجة الإحصائية لها. نتائج البحث يتاول هذا الجزء عرض نتائج البحث وتفسيرها ومناقشتها في ضوء فروض، وأسئلة البحث، وعرض التوصيات والمقترحات. أولا : نتائج البحث وتفسيرها: التحقق من الفرض الأول: - مل ا. كان الفرض الأول ينص على " يوجد فرق دال إحصائياً بين متوسطات درجات

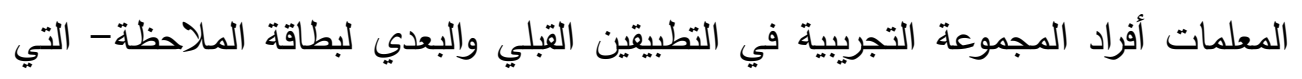

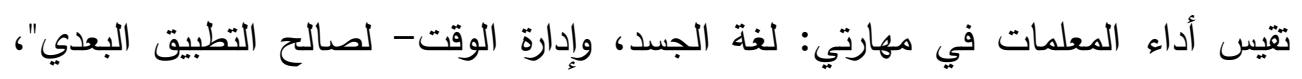
وللتحقق من صحة هذا الفرض من خلال الجدول التالي: جدول (r)

يوضح دلالة الفروق بين متوسطات درجات المعلمات أفراد المجموعة التجربيية في التطبيقين القبلي والبعدي لبطاقة الملاحظة

\begin{tabular}{|c|c|c|c|c|}
\hline$ت$ & الانحراف المعياري & المتوسط الحسابي & ن & بطاقة الملاحظة \\
\hline \multirow{2}{*}{ r ,T } & r,vo & $\leqslant v, 1$ & \multirow{2}{*}{$r$. } & القبلي \\
\hline & $r, 10$ & 1,10 & & البعدي \\
\hline
\end{tabular}

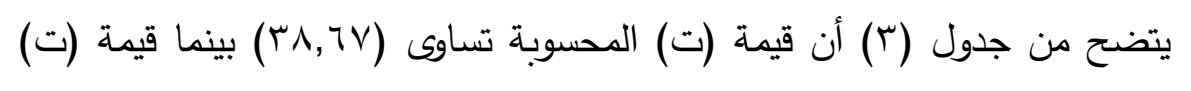

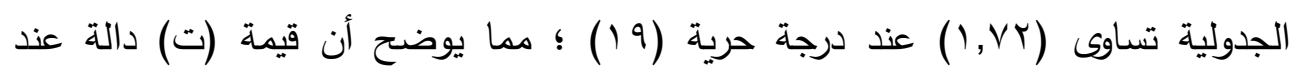
مستوى (0.. •) ؛ وبذلك يتحقق الفرض الأول للبحث، حيث يوجد فرق دال بين متوسطات

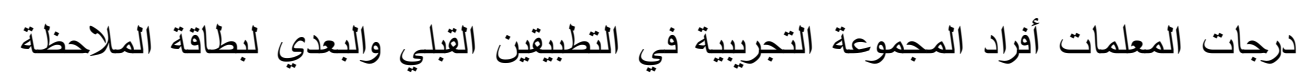




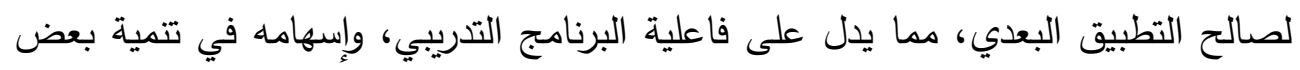

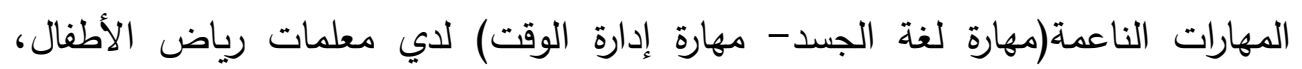

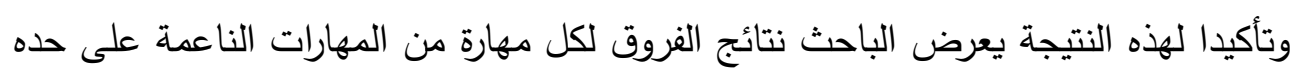

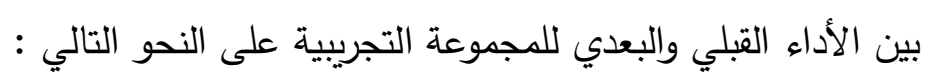

\section{جدول (๕)}

يوضح دلالة الفروق بين متوسطات درجات المعلمات أفراد المجموعة التجرببية في التطبيقين القبلي والبعدي لبطاقة الملاحظة في مهارة لغة الجسد دلهات

\begin{tabular}{|c|c|c|c|c|}
\hline$ت$ & الانحراف المعياري & المتوسط الحسابي & ن ن & بطاقة الملاحظة \\
\hline \multirow{2}{*}{ ro, } & $r, r V$ & $r_{1,1}$ & \multirow{2}{*}{$r}$. & القبلي \\
\hline & $r, \leqslant q$ & 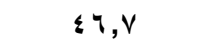 & & البعدي \\
\hline
\end{tabular}

يتضح من جدول (ع) أن قيمة (ت) المحسوبة تساوى (10,1) بينما قيمة (ت)

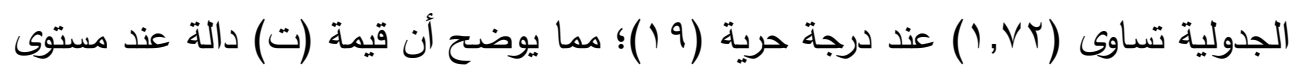
(0. . •)؛ وبذلك يتحقق الفرض الأول للبحث، حيث يوجد فرق دال بين متوسطات درجات

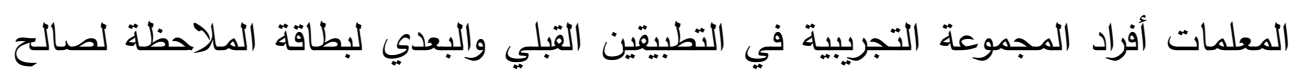

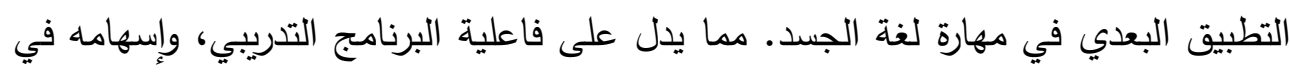

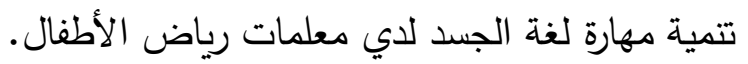

\section{جدول (0)}

يوضح دلالة الفروق بين متوسطات درجات المعلمات أفراد المجموعة التجريبية في التطبيقين القبلي والبعدي لبطاقة الملاحظة في مهارة إدارة الوقت دات

\begin{tabular}{|c|c|c|c|c|}
\hline ت & الانحراف المعياري & المتوسط الحسابي & ن & بطاقة الملاحظة \\
\hline \multirow{2}{*}{ r. } & $1,1 \varepsilon$ & $17, .0$ & \multirow{2}{*}{$r}$. & القبلي \\
\hline & $1, Y V$ & $r \leqslant, \leqslant 0$ & & البعدي \\
\hline
\end{tabular}

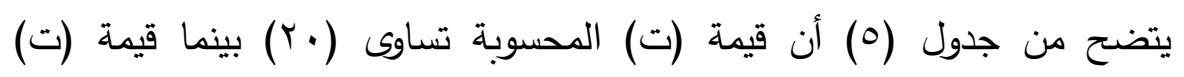

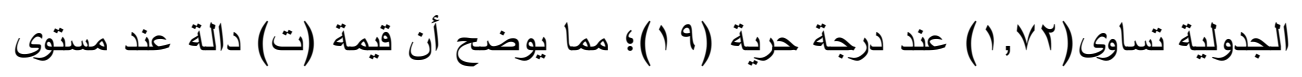


(0., •)؛ وبذلك يتحقق الفرض الأول للبحث، حيث يوجد فرق دال بين متوسطات درجات

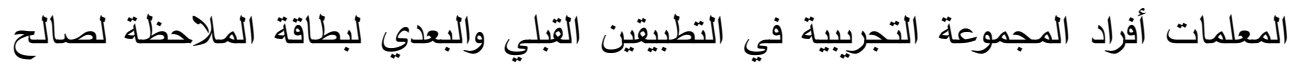

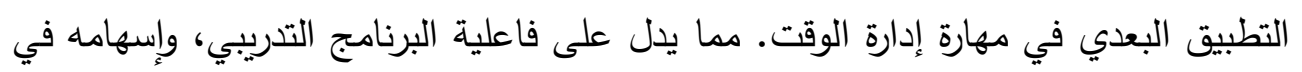
تتمية مهارة إدارة الوقت لدي معلمات رياض الأطفال الدال.

\section{التحقق من صحة الفرض الثاني:}

r- كان الفرض الثاني ينص على " يوجد فرق دال إحصائياً بين متوسطات درجات

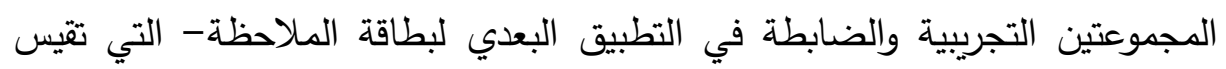

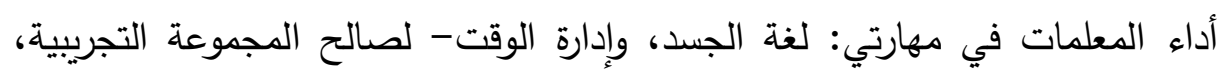
وللتحقق من صحة هذا الفرض يتضح من الجدول التالي:

\section{جدول (7)}

يوضح دلالة الفروق بين متوسطات درجات المعلمات أفراد المجموعتين التجريبية

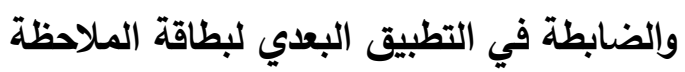

\begin{tabular}{|c|c|c|c|c|}
\hline ت & الانحراف المعياري & المتوسط الحسابي & ن & المجموعة \\
\hline \multirow{2}{*}{ YI, YY } & $\{, \leqslant 1$ & $\leqslant q, \leqslant 0$ & $r$ r. & الضابطة \\
\hline & $r, 10$ & $v 1,10$ & $r$. & التجريبية \\
\hline
\end{tabular}

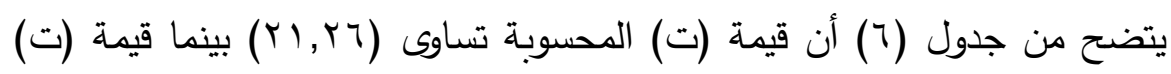

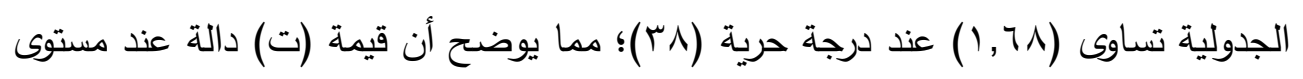
(0., •)؛ وبذلك يتحقق الفرض الثاني للبحث، حيث يوجد فرق دال بين متوسطات درجات

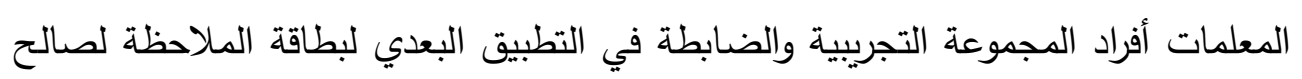

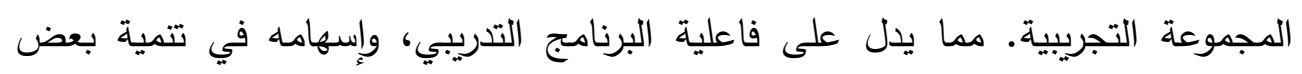

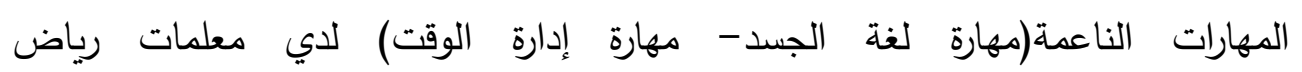
الأطفال (المجموعة التجريبية). 


\section{(v) جدول}

يوضح دلالة الفروق بين متوسطات درجات المعلمات أفراد المجموعتين التجريبية

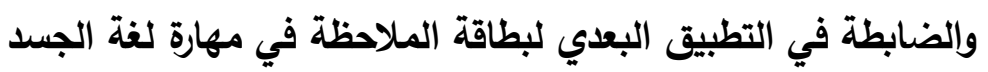

\begin{tabular}{|c|c|c|c|c|}
\hline$ت$ & الانحراف المعياري & المتوسط الحسابي & ن & المجموعة \\
\hline \multirow{2}{*}{10,9} & $r$ & $r \leq$ & $r$. & الضابطة \\
\hline & $r, \leqslant q$ & $\leq \neg, \vee$ & $r \cdot$ & التجريبية \\
\hline
\end{tabular}

يتضح من جدول (V) أن قيمة (ت) المحسوبة تساوى (10,9) بينما قيمة (ت) (ت) (ت) (ت)

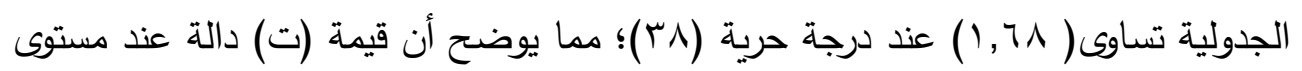
(0. . •)؛ وبذلك يتحقق الفرض الثاني للبحث، حيث يوجد فرق دال بين متوسطات درجات

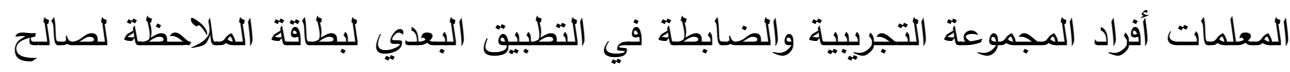

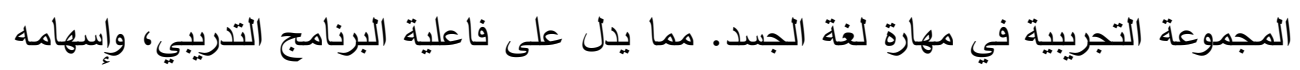
في تتمية مهارة لغة الجسد لدي معلمات رياض الأطفال(المجموعة التجريبية).

\section{(^) جدول (^)}

يوضح دلالة الفروق بين متوسطات درجات المعلمات أفراد المجموعتين التجريبية

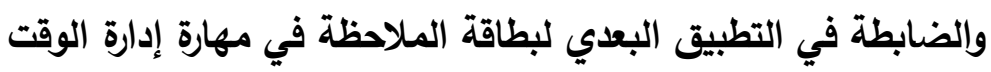

\begin{tabular}{|c|c|c|c|c|}
\hline ت & الانحراف المعياري & المتوسط الحسابي & ن & لمجموعة \\
\hline \multirow{2}{*}{$10, v 0$} & $1, r V$ & $10, \leqslant 0$ & $r \cdot$ & لضابطة \\
\hline & $1, V r$ & $r \leq, \leq 0$ & r. & لتجريبية \\
\hline
\end{tabular}

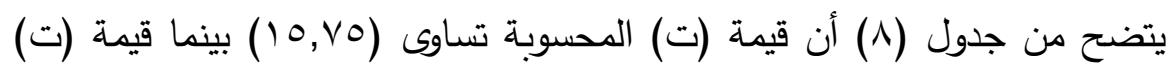

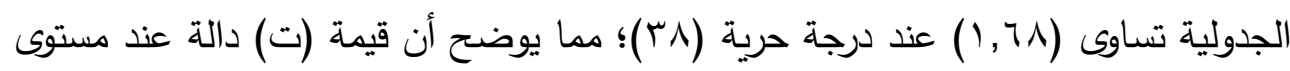
(0. . •)؛ وبذلك يتحقق الفرض الثاني للبحث، حيث يوجد فرق دال بين متوسطات درجات

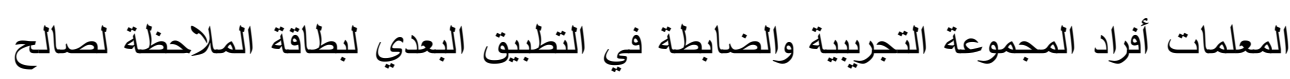

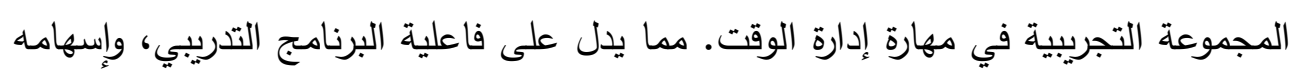
في تتمية مهارة إدارة الوقت لدي معلمات رياض الأطفال(المجموعة التجريبية). 


\section{التحقق من صحة الفرض الثالث:}

ץ- كان الفرض الثالث ينص على " يوجد فرق دال إحصائياً بين متوسطات درجات المعلمات أفراد المجموعة التجريبية في التطبيقين القبلي والبعدي للإختبار التحصيلي- في مهارتي: لغة الجسد، وإدارة الوقت- لصالح التطبيق البعدي.، وللتحقق من هذا الفرض يتضح من الجدول التالي:

\section{جدول (9)}

يوضح دلالة الفروق بين متوسطات درجات المعلمات أفراد المجموعة التجريبية في التطبيقين القبلي والبعدي في الاحتبار التحصيلي

\begin{tabular}{|c|c|c|c|c|}
\hline ت & الانحراف المعياري & المتوسط الحسابي & ن & الاختبار \\
\hline \multirow{2}{*}{19,8} & $\uparrow, r \wedge$ & ri,ro & \multirow{2}{*}{$r}$. & القبلي \\
\hline & $r, q \leqslant$ & $r q, q$ & & البعدي \\
\hline
\end{tabular}

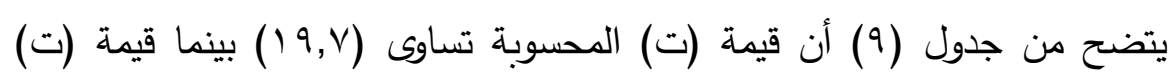

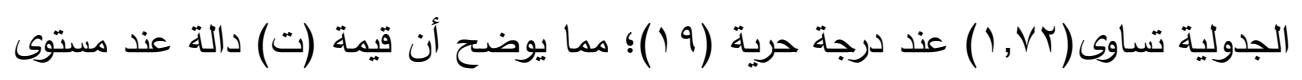
(0., •)؛ وبذلك يتحقق الفرض الثالث للبحث، حيث يوجد فرق دال بين متوسطات درجات

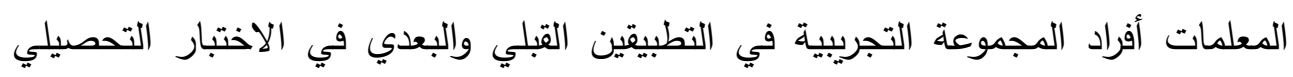

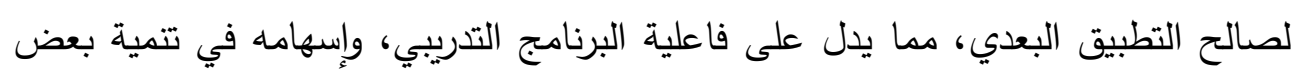

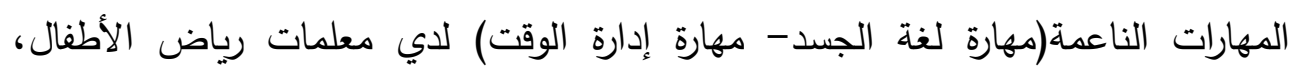

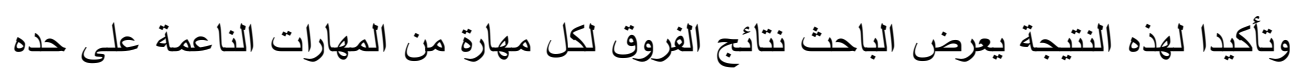
بين الأداء القبلي والبعدي للمجموعة التجريبية على النحو التالي : 


\section{جدول (1.) - (1) - (2)}

يوضح دلالة الفروق بين متوسطات درجات المعلمات أفراد المجموعة التجريبية في

التطبيقين القبلي والبعدي للاختبار التحصيلي في مهارة لغة الجسد دلدات

\begin{tabular}{|c|c|c|c|c|}
\hline ت & الانحراف المعياري & المتوسط الحسابي & ن & الاختبار \\
\hline \multirow{2}{*}{$1 V, \leqslant 9$} & $1, r v$ & $9, \vee \vee 0$ & \multirow{2}{*}{$r}$. & القبلي \\
\hline & $r, Y r$ & 19,1 & & البعدي \\
\hline
\end{tabular}

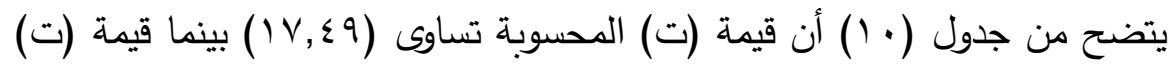

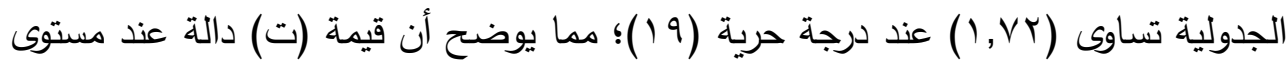
(0. . •)؛ وبذلك يتحقق الفرض الثالث للبحث، حيث يوجد فرق دال بين متوسطات درجات

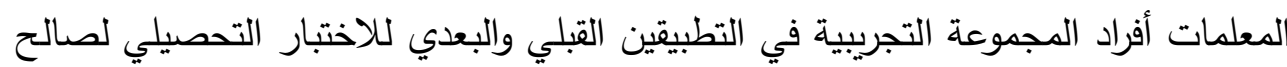
التطبيق البعدي في مهارة لغة الجسد. مما يدل على فاعلية البرنامج التدريبي، وإسهامه في تتمية مهارة لغة الجسد لاي معلمات رياض الأطفال (المجموعة التجريبية).

$$
\text { جدول (11) }
$$

يوضح دلالة الفروق بين متوسطات درجات المعلمات أفراد المجموعة التجريبية في التطبيقين القبلي والبعدي للاختبار التحصيلي في مهارة إدارة الوقت

\begin{tabular}{|c|c|c|c|c|}
\hline ت & الانحراف المعياري & المتوسط الحسابي & ن & الاختبار \\
\hline \multirow{2}{*}{17,97} & $1, \mu_{1}$ & 11,0 & \multirow{2}{*}{$r$. } & القبلي \\
\hline & $r, r T$ & $r \cdot, \Lambda$ & & البعدي \\
\hline
\end{tabular}

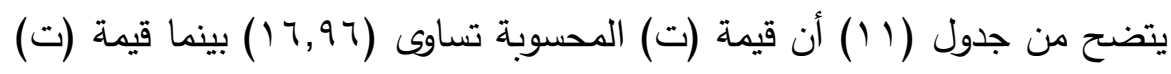

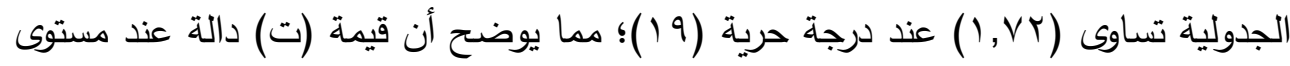
(0. . •)؛ وبذلك يتحقق الفرض الثالث للبحث، حيث يوجد فرق دال بين متوسطات درجات

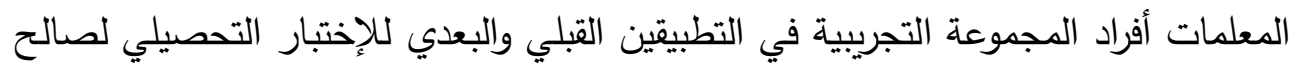
التطبيق البعدي في مهارة إدارة الوقت. مما يدل على فاعلية البرنامج التدريبي، وإسهامه في لئي تتمية مهارة إدارة الوقت لدي معلمات رياض الأطفال (المجموعة التجريبية). 
التحقق من صحة الفرض الرابع :

ع - كان الفرض الرابع ينص على " يوجد فرق دال إحصائياً بين متوسطات درجات المجموعتين التجريبية والضابطة في التطبيق البعدي للإختبار التحصيلي- في مهارتي: لغة الجسد، وإدارة الوقت - لصالح المجموعة التجريبية.

$$
\text { جدول (r) }
$$

يوضح دلالة الفروق بين متوسطات درجات المعلمات أفراد المجموعتين التجريبية والضابطة في التطبيقين البعدي للإختبار التحصيلي

\begin{tabular}{|c|c|c|c|c|}
\hline 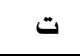 & الانحراف المعياري & المتوسط الحسابي & ن & المجموعة \\
\hline \multirow{2}{*}{$1+1$} & $r, 97$ & $r r, q 0$ & $r$. & الضابطة \\
\hline & $r, q \leqslant$ & $r q, q$ & r. & التجربية \\
\hline
\end{tabular}

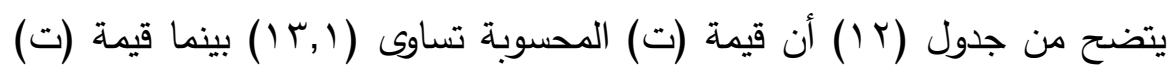

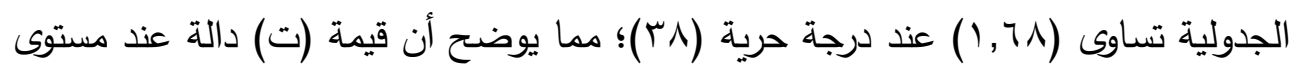
(0.. •)؛ وبذلك يتحقق الفرض الرابع للبحث، حيث يوجد فرق دال بين متوسطات درجات

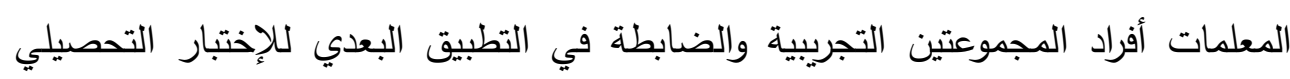

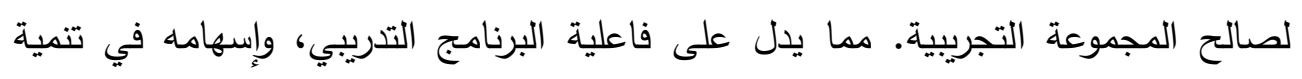

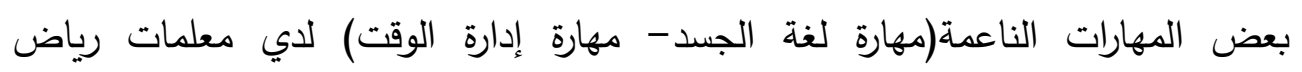
الأطفال(المجموعة التجريبية).

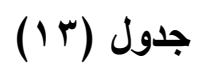

يوضح دلالة الفروق بين متوسطات درجات المعلمات أفراد المجموعتين التجريبية

\begin{tabular}{|c|c|c|c|c|}
\hline 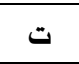 & الانحراف المعياري & المتوسط الحسابي & ن ن & المجموعة \\
\hline \multirow{2}{*}{$\mid r, 1$} & $1, \varepsilon \wedge$ & 11,1 & $r$. & الضابطة \\
\hline & Y,YY & 19,1 & r. & التجريبية \\
\hline
\end{tabular}

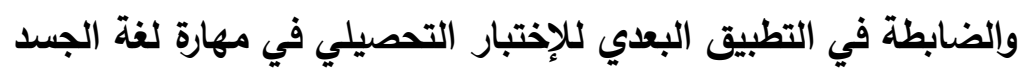




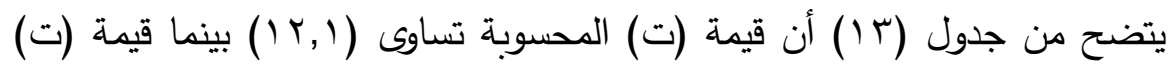

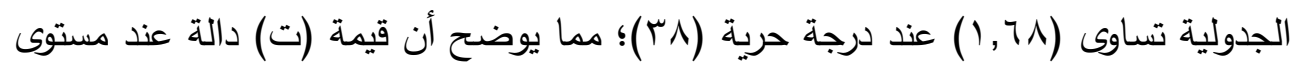
(0. . •)؛ وبذلك يتحقق الفرض الرابع للبحث، حيث يوجد فرق دال بين متوسطات درجات

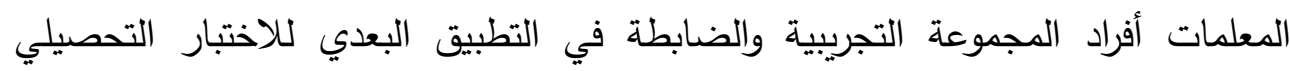

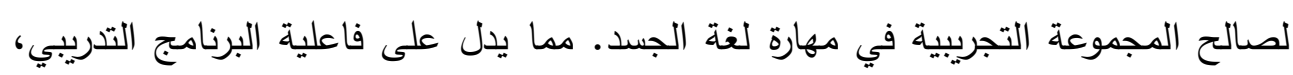
وإسهامه في تتمية مهارة لغة الجسد لدي معلمات رياض الأطفال (المجموعة التجريبية).

$$
\text { جدول (\& ) }
$$

يوضح دلالة الفروق بين متوسطات درجات المعلمات أفراد المجموعتين التجريبية والضابطة في التطبيق البعدي للاختبار التحصيلي في مهارة إدارة الوقت لتوبن

\begin{tabular}{|c|c|c|c|c|}
\hline 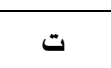 & الانحراف المعياري & المتوسط الحسابي & ن ن & المجموعة \\
\hline \multirow{2}{*}{$11, \mathrm{rV}$} & $1, V Y$ & $1 \%, \wedge 0$ & $r$. & الضابطة \\
\hline & $r, Y^{\prime}$ & $r \cdot, \Lambda$ & $r$. & التجربية \\
\hline
\end{tabular}

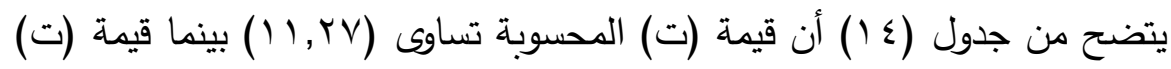

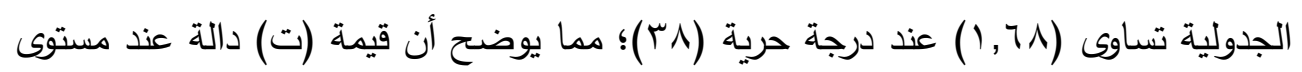
(0., •)؛ وبذلك يتحقق الفرض الرابع للبحث، حيث يوجد فرق دال بين متوسطات درجات

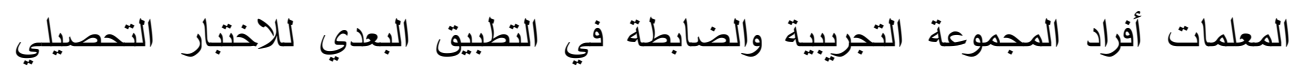

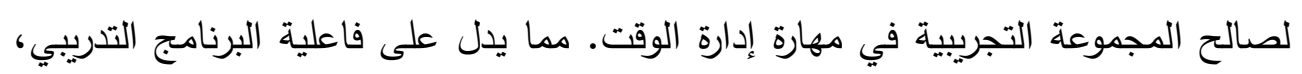
وإسهامه في تتمية مهارة إدارة الوقت لدي معلمات رياض الأطفال (المجموعة التجريبية). التحقق من صحة الفرض الخامس: ه- كان الفرض الخامس ينص على "يوجد ارتباط طردي بين متوسطات درجات المعلمات

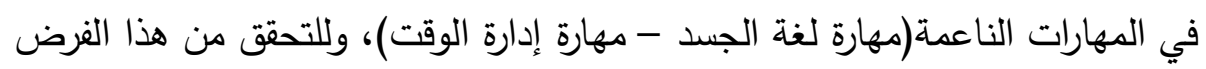
يتضح من الجدولين التاليين: 


\section{جدول (10)}

يوضح معامل الارتباط بين متوسطات درجات المعلمات في المهارات الناعمة (مهارة لغة الجسد - مهارة إدارة الوقت) للاختبار التحصيلي

\begin{tabular}{|c|c|c|c|c|c|}
\hline ت & الارتباط & الانحراف المعياري & الحسابي & ن & المهارة \\
\hline \multirow{2}{*}{$r, \cdot \varepsilon$} & \multirow{2}{*}{$\cdot, \infty 0$} & $\Lambda, Y Y$ & $v \cdot, v \varepsilon$ & \multirow{2}{*}{$r}$. & لغة الجسد \\
\hline & & $\Lambda, \cdot V$ & $V \varepsilon, Y \wedge$ & & إدارة الوقت \\
\hline
\end{tabular}

يتضح من جدول (10) أن قيمة معامل الارتباط تساوي (00,·)، أي أن هناك

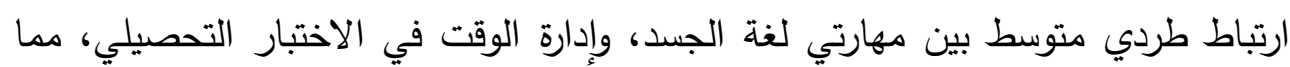
يؤكد صحة الفرض الخامس.

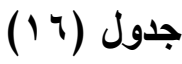

يوضح معامل الارتباط بين متوسطات درجات المعلمات في المهارات الناعمة(مهارة لغة

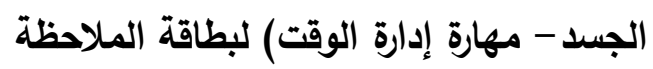

\begin{tabular}{|c|c|c|c|c|c|}
\hline ت & معامل الارتباط & الانحراف & الحسابي & ن ن & المهارة \\
\hline \multirow{2}{*}{$0, \varepsilon$} & \multirow{2}{*}{.,$\infty 0$} & $\varepsilon, Y_{O}$ & $V Y, q V$ & \multirow{2}{*}{$r}$. & لغة الجسد \\
\hline & & $r, \wedge q$ & $\wedge 1,0$ & & إدارة الوقت \\
\hline
\end{tabular}

يتضح من جدول (7 1) أن قيمة معامل الارتباط تساوي (0,·)، أي أن هناك ارتباط طردي متوسط بين مهارتي لغة الجسد، وإدارة الوقت في بطاقة الملاحظة، مما يؤكد صحة الفرض الخامس.

وتؤكد نتائج العمليات الإحصائية للفروض البحثية السابقة علي الفاعلية الإيجابية للبرنامج التدريبي، وإسهامه في تتمية المهارات الناعمة(مهارة لغة الجسد - مهارة إدارة الوقت) لدي معلمات رياض الأطفال(المجموعة التجريبية)؛ ويرجع ذلك إلي التنظيم المقترح 
للبرنامج التدريب(موضع التجريب)، حيث أتاح التنظيم المقترح الفرصة للنمو التتابعى

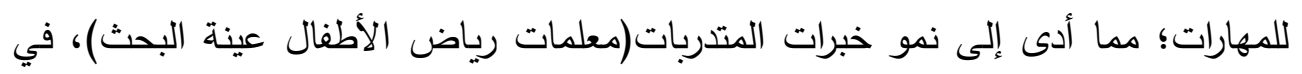

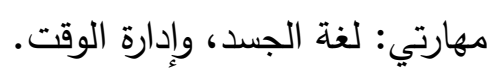

وبهذا يكون الباحث قد أجاب علي السؤال الثالث من أسئلة البحث، والذي ينص

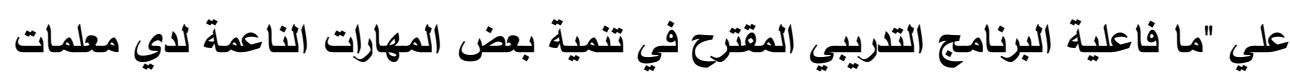

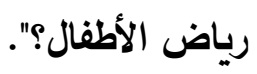

ومن ثم تحقق الهدف الثالث من أهداف البحث وهو: قياس فاعلية البرنامج التدريبي في تنمية بعض المهارات الناعمة(مهارة لغة الجسد- مهارة إدارة الوقت) لاي

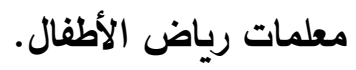

\section{تفسير نتائج البحث ومناقشتها:}

نجاح معلمة الروضة في القيام بأدوارها الجديدة المتوقعة، يستلزم امتلاكها جملة من

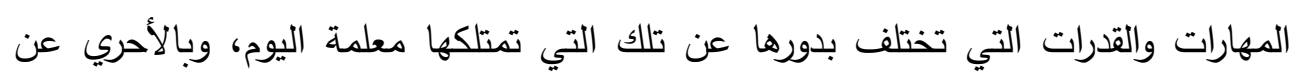

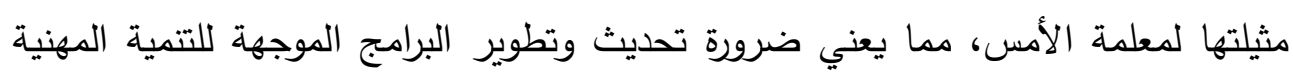

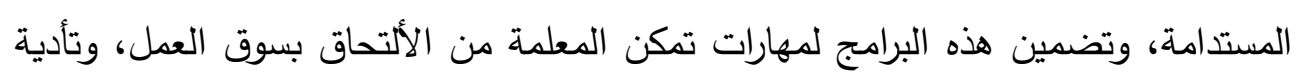

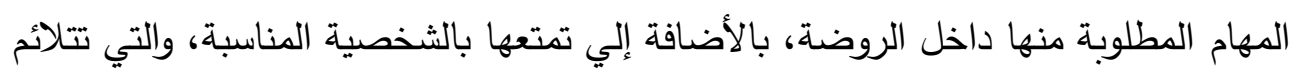

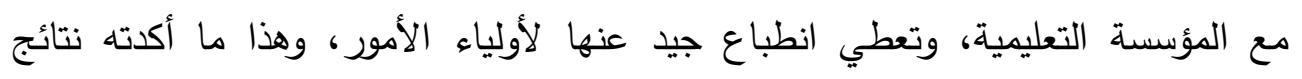
البحث الحالي بعد تدريب معلمات الروضة - عينة البحث - علي بعض المهارات الناعمة.

\section{ومن النتائج السابقة يمكن استنتاج ما يلي:}

- - أن معلمات المجموعة التجريبية الذين تعرضوا للبرنامج التدرببي، قد حققوا نمواً في

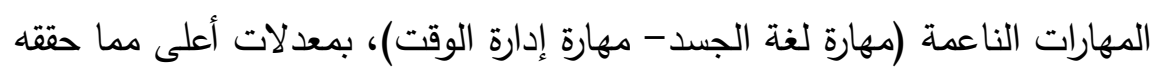
معلمات المجموعة الضابطة. 
- - أن البرنامج التدريبي الذي تم بناؤه للمعلمات أثبت فعاليته، وظهر ذلك من تطبيق

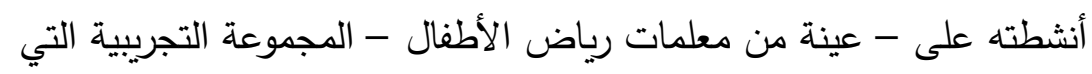

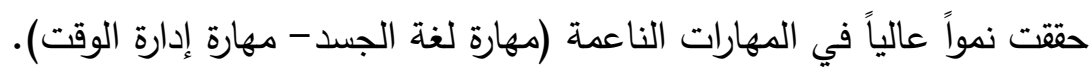

\section{وقد يرجع تحقق هذه النتائج إلى:}

المزج ما بين الجانب النظري والعملي، اعتماد أسلوب الحوار والعمل الجماعي،

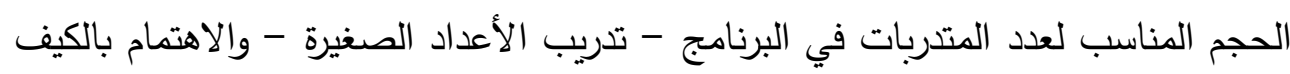
دون الكم، التحديد الدقيق لأهداف البرنامج التدريبي، بحيث تصف البرناهي السلوك النهائي للمتدربة،

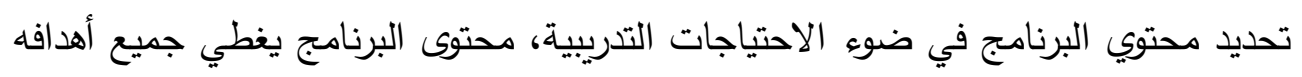

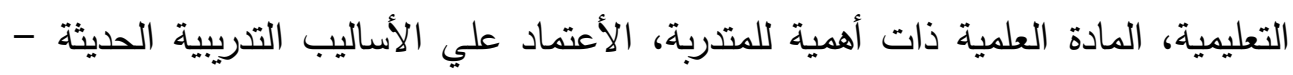

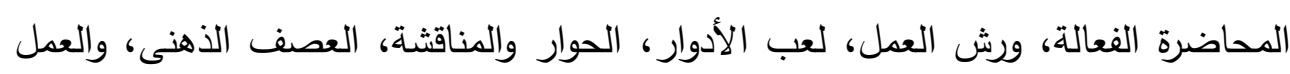

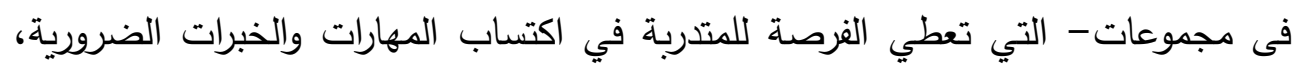
اختيار معينات التدريب التى تسهم في تحقيق أهداف البرنامج، مثل العروض التقديمية (بور

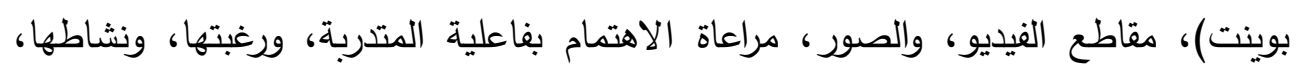

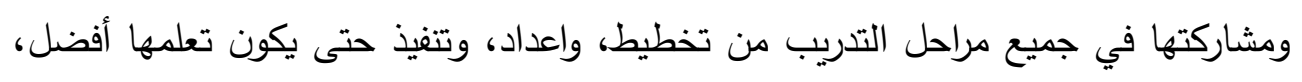

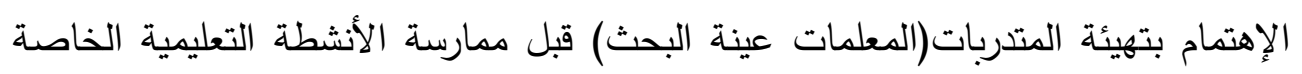

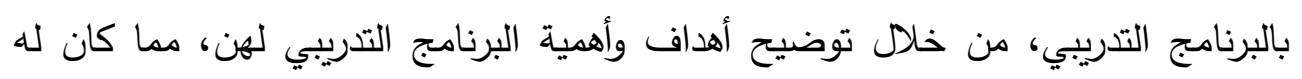

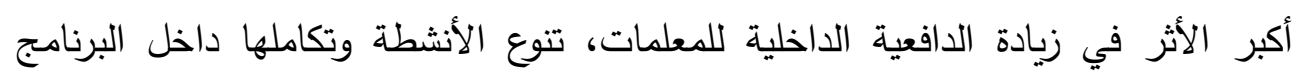

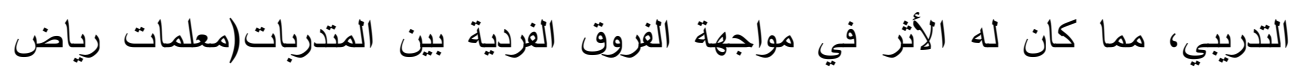

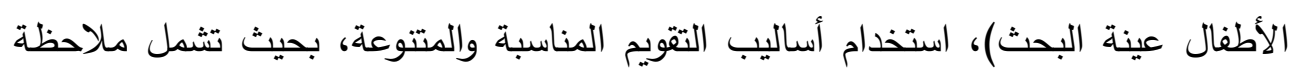
سلوك المتدربة، وإنتاجها، والاختبار التحصيلي، وتقويم المتدربة لنفسها ولزملائها أثناء

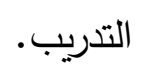

وتتفق نتائج هذا البحث مع نتائج الكثير من البحوث و الدراسات السابقة التي

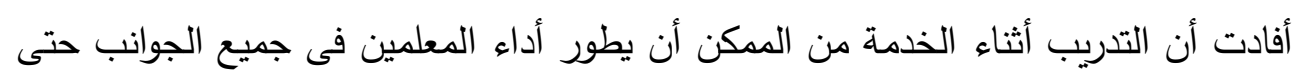

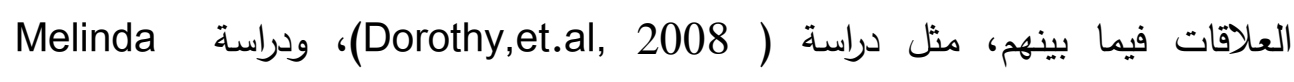
(Bonsall,1999) 


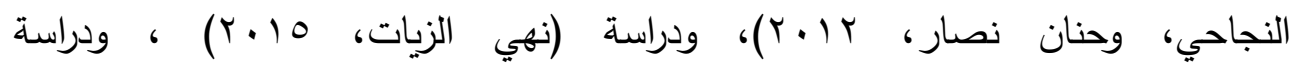
.(Vasudevan, and at hers, 2015)

كما توصلت بعض الدراسات السابقة إلي أن تدريب المعلمين أثناء الخدمة يساعد

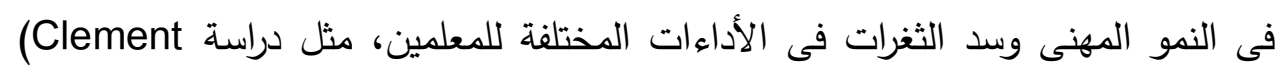

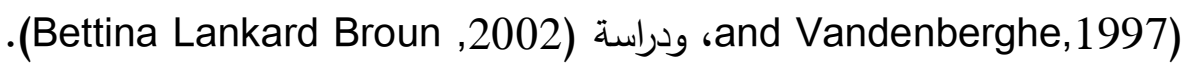
وأكدت بعض الدراسات على أهمية التدريب المستمر لمعلمات الروضة، وأهمية بناء

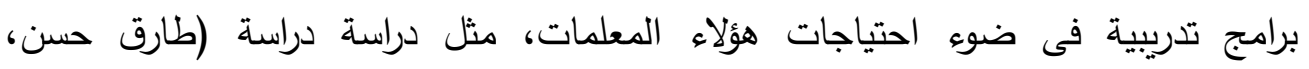

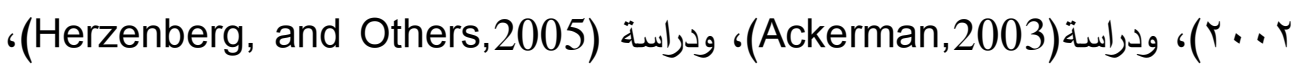

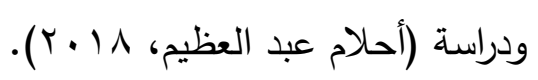

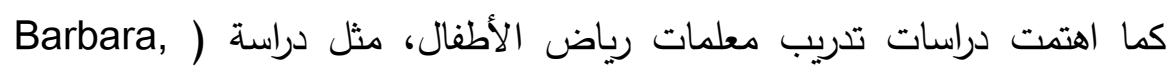

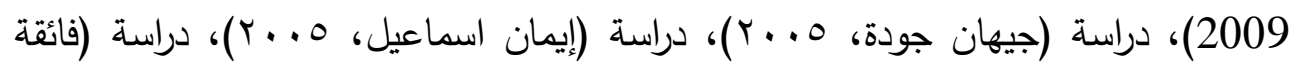

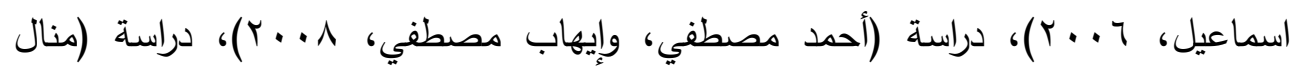

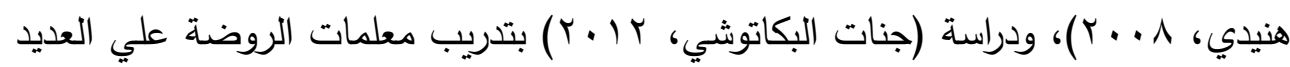

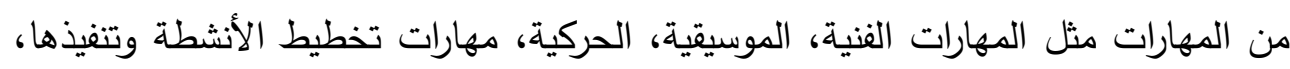
وإدارة غرفة النشاط.

\section{توصيات البحث:}

مما سبق وفى ضوء نتائج البحث يوصى الباحث بالأتى:

- - علي خريجات شعب، وكليات رياض الأطفال الباحثات عن عمل أن يقمن بتطوير مهاراتهن الخاصة باستخدام لغة الجسد، وإدارة الوقت لتصن.

- علي معلمات رياض الأطفال توظيف المهارات الناعمة في المواقف التعليمية داخل

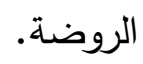

- - الأهتمام بتدريب خريجي كليات التربية للطفولة المبكرة، وكليات التربية - تخصص -

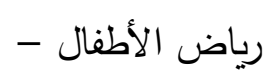


- - علي استخدام المهارات الناعمة، وتوظيفها في تعليم الأطفال.

- - استخدام استراتيجيات تعليمية متنوعة لتنمية المهارات الناعمة لمعلمات الروضة.

- - تزويد المكتبة العربية بالبحوث والدراسات والكتب التى تهتم بالمهارات الناعمة. - الإهتمام بقياس المهارات الناعمة لمعلمات الروضة، وإعداد أدوات التقويم المناسبة لذلك، مع ضرورة تدريب معلمات الروضة على استخدام تلك الأدوات. بحوث مقترحة:

- اجراء دراسة عن المهارات الناعمة لدي معلمات رياض الأطفال وعلاقتها بالتعامل مع أولياء الأمور / الطفل.

- تصميم برامج تدريبية لتنمية باقي المهارات الناعمة لاي معلمات الروضة. - تصميم برنامج تعليمى متعدد الوسائط لتتمية المهارات الناعمة لمعلمات الروضة وقياس فعاليته

- اجراء دراسة استكثافية بالاحتياجات التدربية اللازمة لمعلمات رياض الأطفال في مجال المهارات الناعمة. 


\section{مراجع}

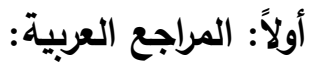

ا. إبراهيم حمد العقيد(1 . . ب): العادات العشر للشخصية الناجحة، دار المعرفة للتمية البشرية، الرياض.

r. أحلام عبد العظيم حامد(1) ( r): دراسة تقويمية للكفايات التعليمية لمعلمات رياض الأطفال بمحافظة الجبيل بالمملكة العربية السعودية، المؤتمر الدولي الأول لكلية رياض الأطفال بجامعة أسيوط،" بناء طفل لمجتمع أفضل في ظل المتغيرات المعاصرة "، فبراير 1 1 • ب، كلية رياض الأطفال، جامعة أسيوط.

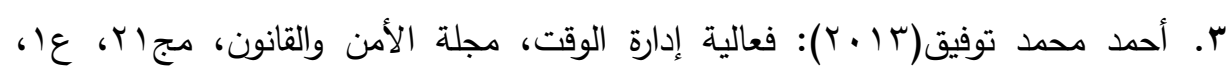
يناير ، أكاديمية شرطة دبي.

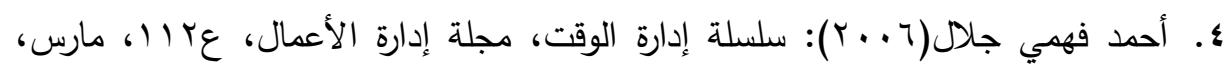

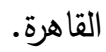

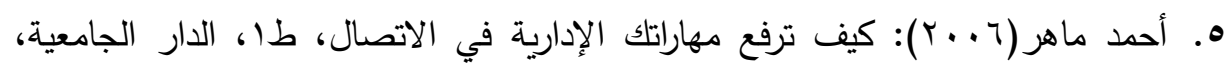

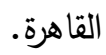

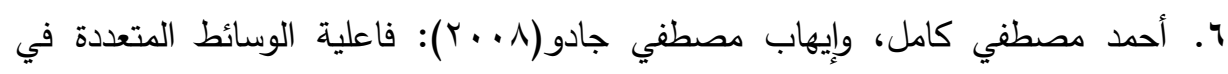
إكساب معلمات رياض الأطفال مهارات تصميم وإنتاج البرمجية التعليمية لطفل الروضة، معهد الدراسات والبحوث التربوية، جامعة القاهرة، والجمعية العربية لتكنولوجيا التربية.

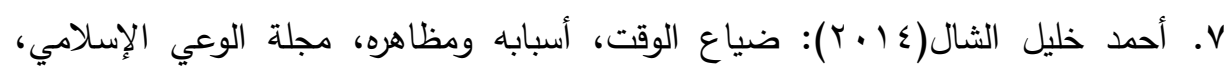
س 01، ع910، يوليو، وزارة الأوقاف والشئون الإسلامية، الكويت.

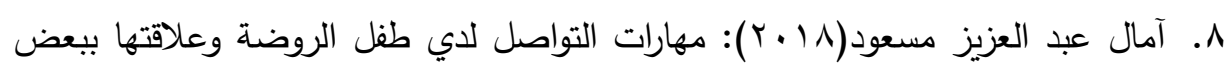
المتغيرات، مجلة العلوم التربوية والنفسية، مج9 ا، ع ا، مارس، البحرين.

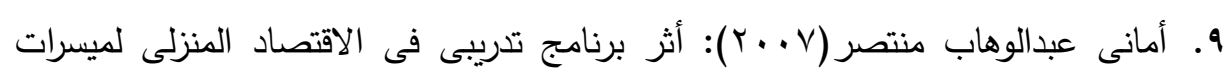
مراكز الطفل على تتمية أدائهن التدريسى فى بعض محافظات صعيد مصر، مجلة دراسات تربوية واجتماعية، مجب ا، عءء، اكتوبر ، كلية التربية، جامعة حلوان. 
• 1.أمير تاج الدين(^ . . r): الثقة بالنفس، ط؟، كنوز للنشر والتوزيع، القاهرة.

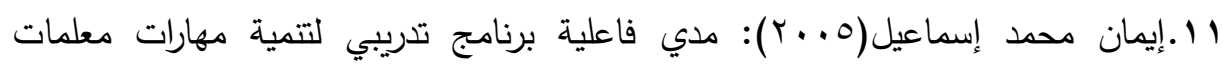

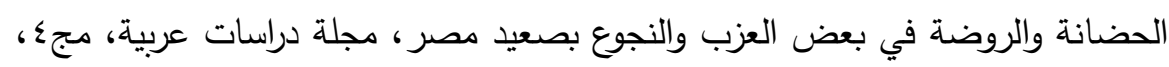

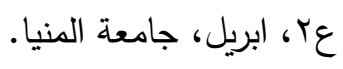

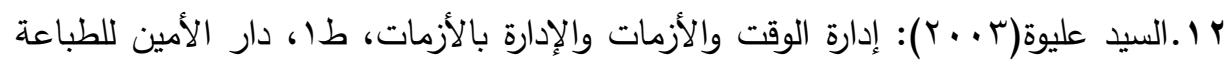
والنشر والتوزيع، القاهرة.

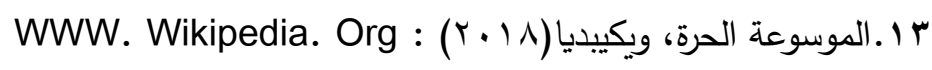
؛ ا.بشير العلاق(9 ..ب): أساسيات إدارة الوقت، دار اليازوري العلمية للنشر والتوزيع، عمان.

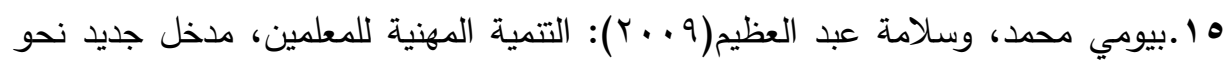
إصلاح التعليم، طا، دار الفكر العربي، القاهرة. 14 .ثناء إبراهيم فرحات(بدون تاريخ): إدارة الوقت في المكتبات الجامعية بالقاهرة الكبري، دار الثقافة العلمية، الأسكندرية.

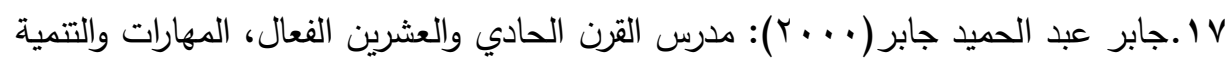
المهنية، طا، دار الفكر العربي، القاهرة.

1 ا.جل بروكس( (. ب): قدرات التدريب والتطوير، دليل عملى، ترجمة عبد الاله إسماعيل،

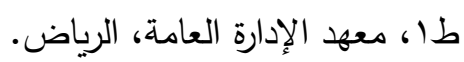

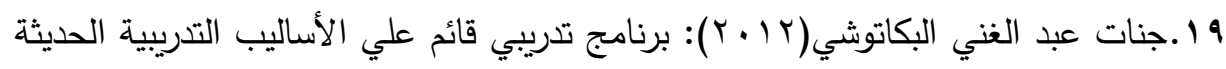

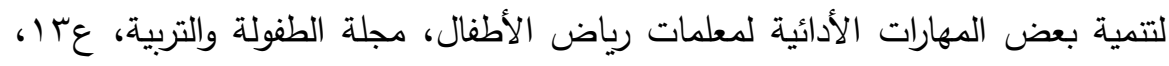
السنة الرابعة، أكتوبر ، كلية رياض الأطفال، جامعة الأسكندرية.

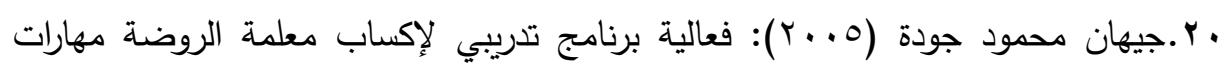

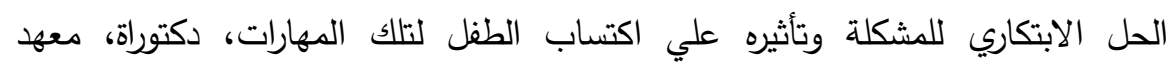
الدراسات والبحوث التربوية، جامعة القاهرة. 


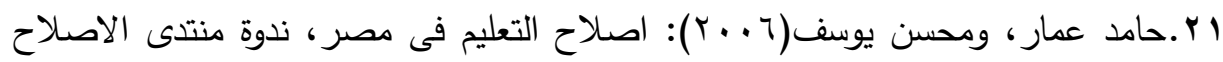

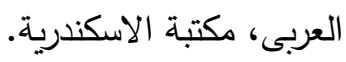

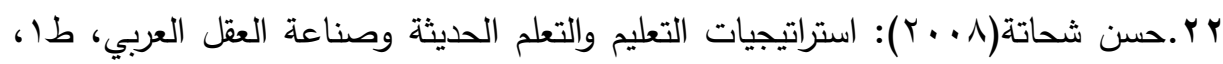

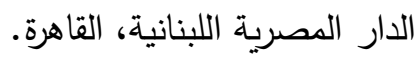

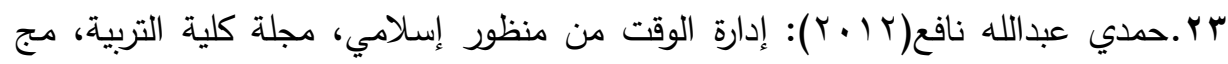

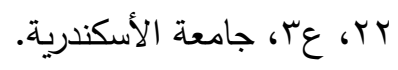

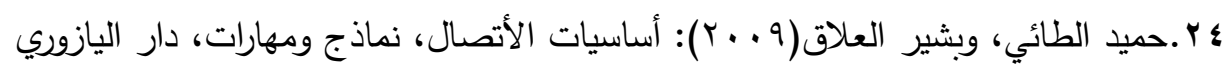
العلمية للنشر والتوزيع، عمان.

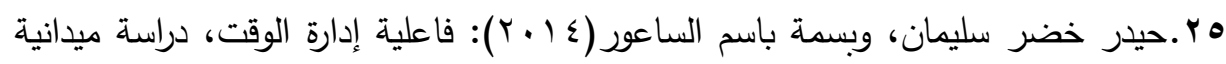

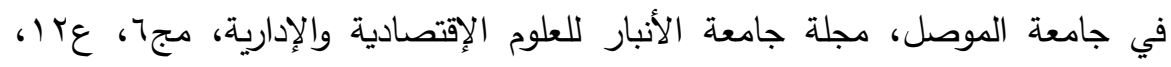

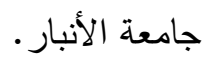

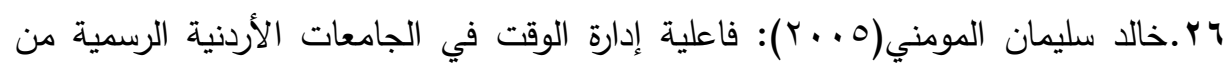

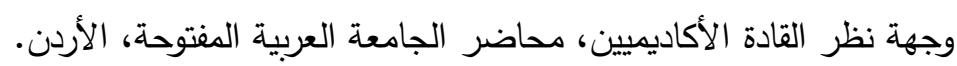

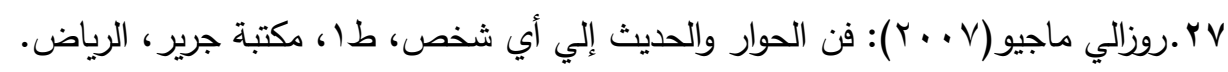

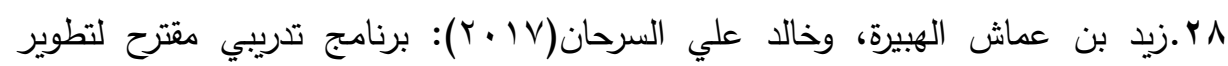

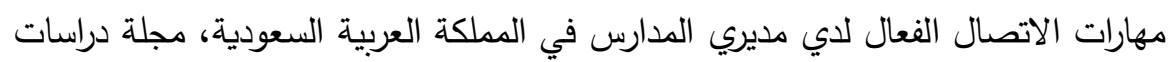
في العلوم التربوية، مج ؟ ؛، ملحق، عمادة البحث العلمي، جامعة الأردن، عمان. 9. بامية مهداوي(10 ـ r): إدارة الوقت بين المفهوم والأهمية، مجلة جيل العلوم الإنسانية

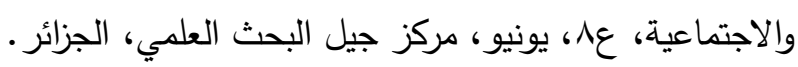

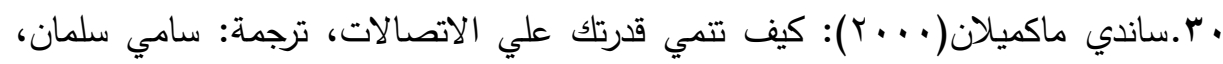

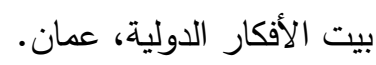

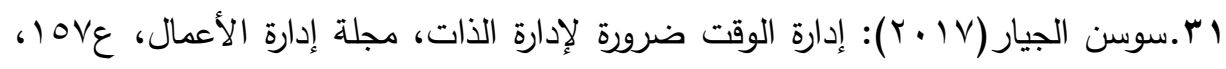
يونيه، القاهرة. 


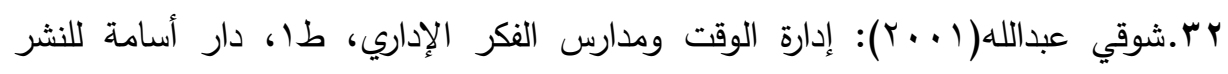
والتوزيع، عمان.

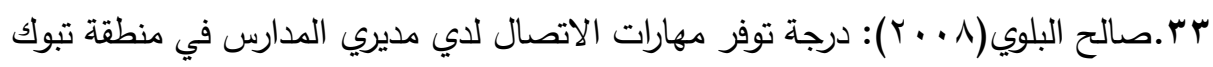

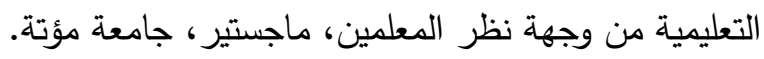

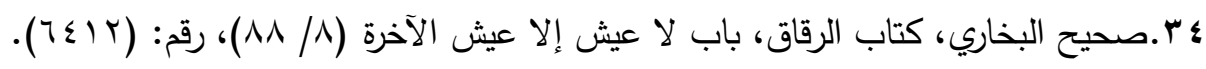

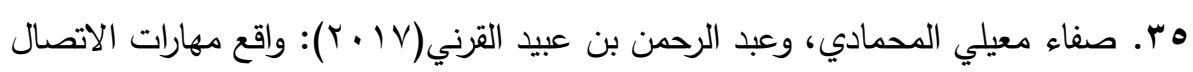

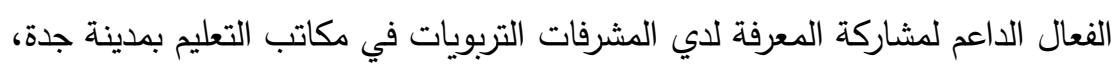
مجلة دراسات المعلومات، عه ا، يناير ، جمعية المكتبات والمعلومات السعودية.

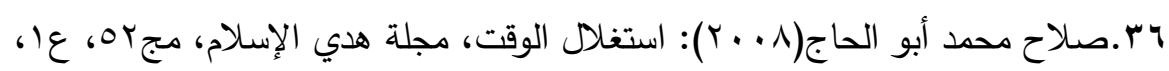

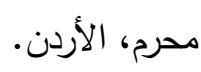

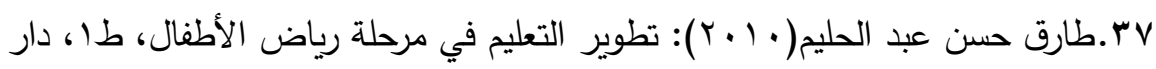
العلوم للنشر والتوزيع، القاهرة.

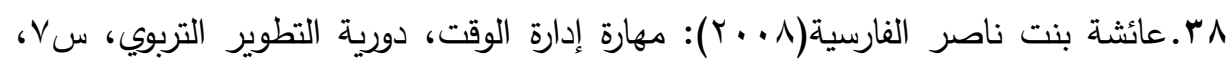
عَ" ؛ ، ديسمبر ، وزارة التربية والتعليم، سلطنة عمان.

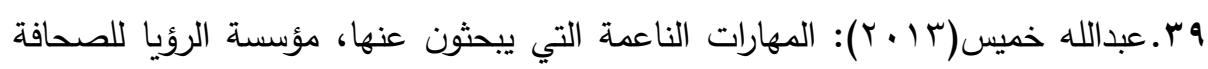
والنشر ، عمان.

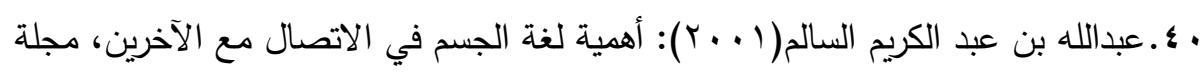

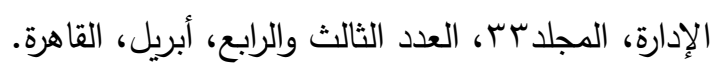

اء.عبد الرازق حمايمي، ومحمد الطاهر طعبلي( rا.ب ): مهارات الاتصال لاي المدرس

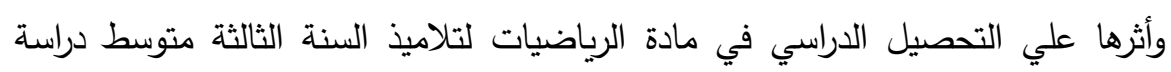

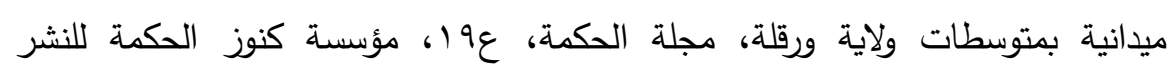

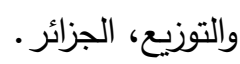

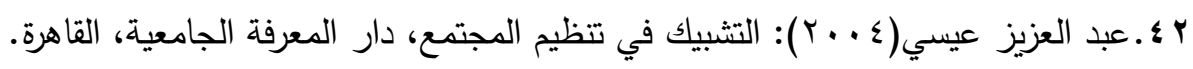




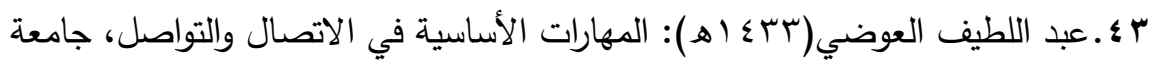
الملك سعود، الرياض.

؟ ؛ .عزيزة عبد الله طيب، ووفاء مشعان الثمري(7 ( • ؟): ممارسات مهارات الاتصال الفعال

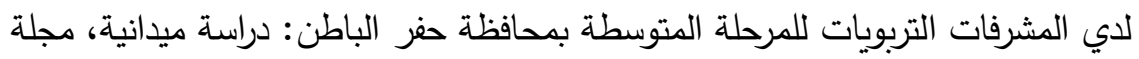
دراسات عربية في التربية وعلم النفس، عدد خاص، ديسمبر، رابطة التربويين العرب. 0ـ ـ.علا نعيم حجاج(؟ ( ب): دور المهارات الناعمة في عملية اقتناص الوظائف الإدارية،

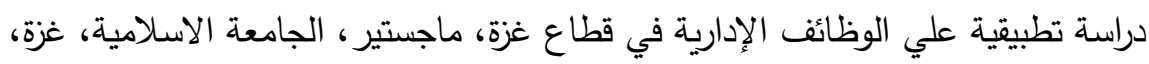
فلسطين.

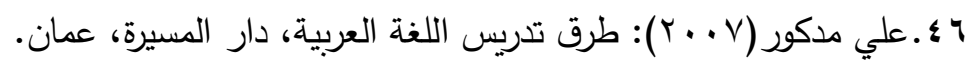

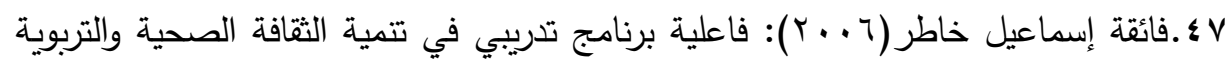

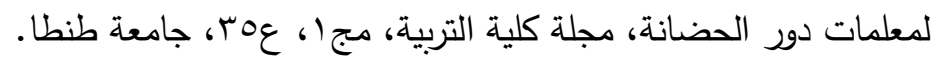

^ ؛ .فايزة سويلم(ب ا • ץ): المهارات الناعمة، مؤسسة الرؤيا للصحافة والنشر ، مسقط .

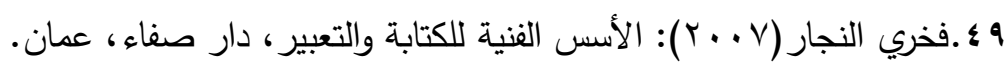

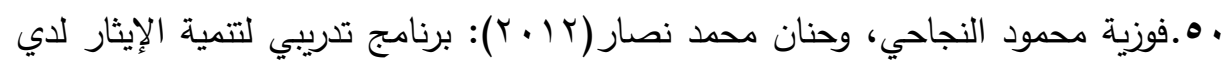

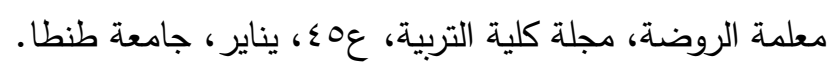

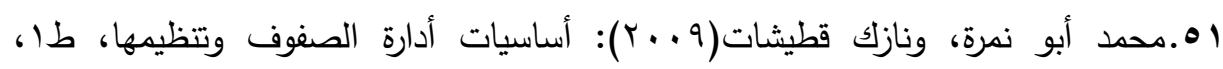
المكتبة الوطنية، عمان.

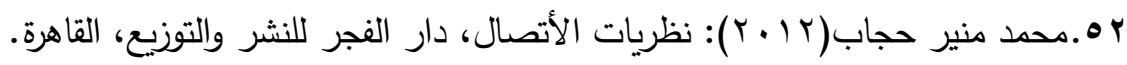

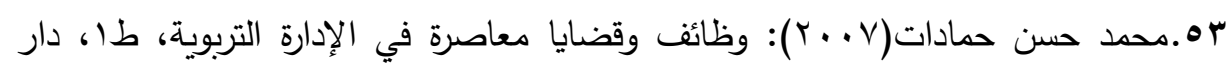
الحامد للنشر والتوزيع، عمان.

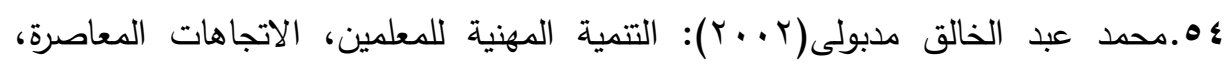
المداخل الاستراتيجية، طا، مكتبة العين، الأمارات.

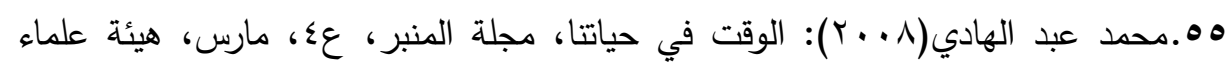
السودان. 
צه . محمد ممتاز (9 . . ؟): المفاتيح السبعة للشخصية الناجحة، كنوز للنشر والتوزيع، القاهرة.

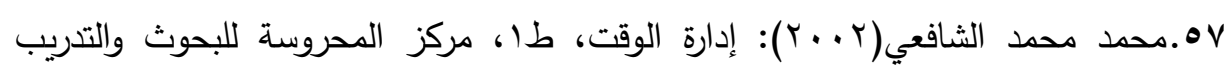

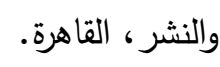

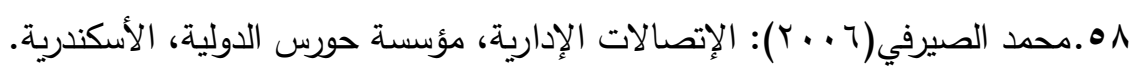

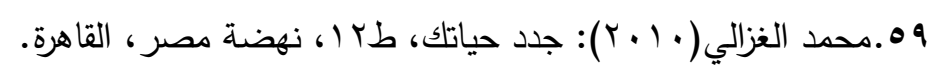

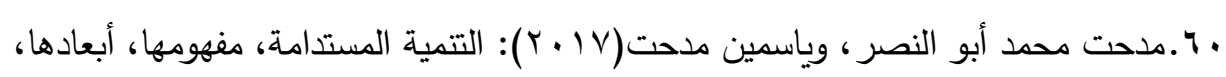
مؤشراتها، طا، المجموعة العربية للتدريب والنشر ، القاهرة.

ال . ممدوح عبد الرحيم أحمد(1 ( • Y): دليل مرجعي للتمية المهنية للمعلمين كمدخل لمجتمع التعلم، المؤتمر الدولي الأول لكلية رياض الأطفال بجامعة أسيوط، " بناء طفل لمجتمع

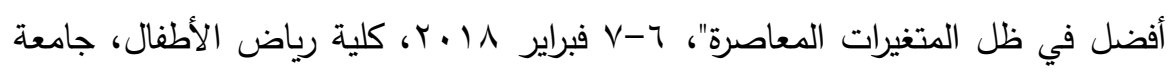
أسيوط.

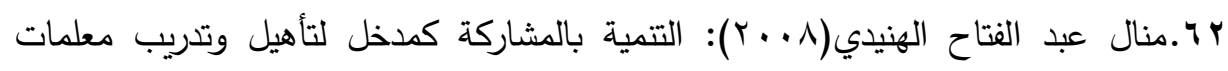
الروضة غير المؤهلات في المناطق العشوائية في مجال مناهج وطرق تدريس التربية

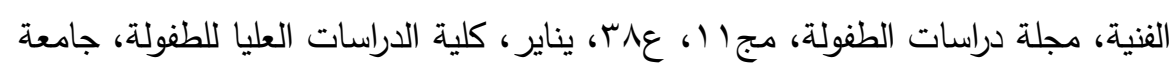
عين شمس. با..مني يوسف شفيق(1) (Y): مهارات الأتصال الفعال، المنظمة العربية للتتمية الإدارية، القاهرة.

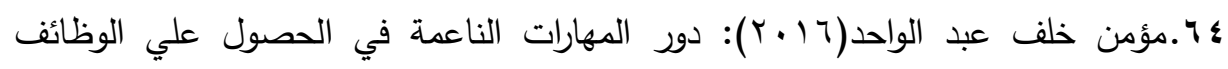
الأكاديمية: دراسة تطبيقية علي وزارة التربية والتعليم العالي- قطاع غزة، مجلة جامعة

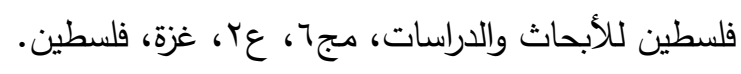

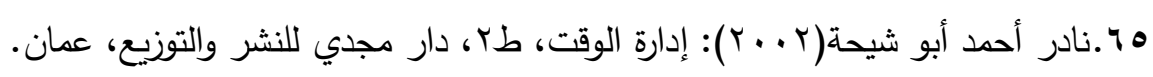
צ 7 .نبيل عبد الهادي، وآخرون(0 . . ץ): مهارات في اللغة والتفكير، دار المسيرة، عمان. 


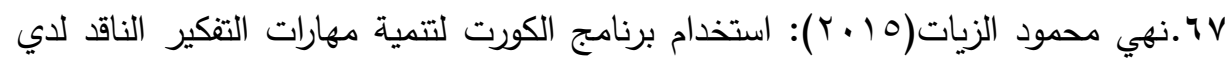

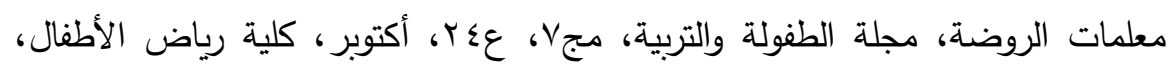
جامعة الأسكندرية.

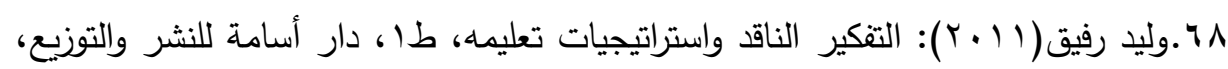
عمان.

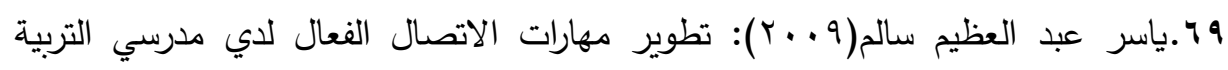

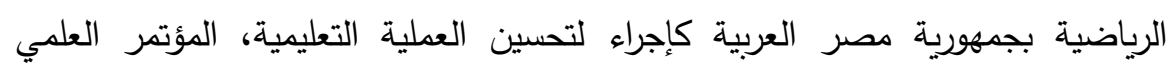

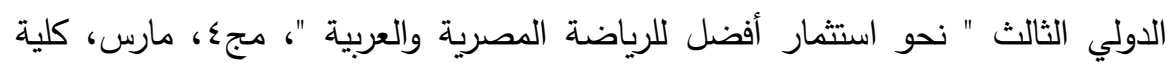
التربية الرياضية للبنين، جامعة الزقازيق.

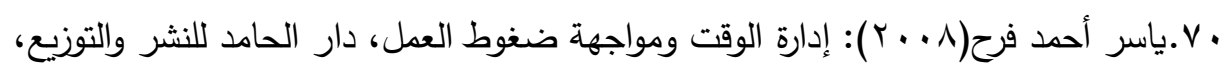
عمان.

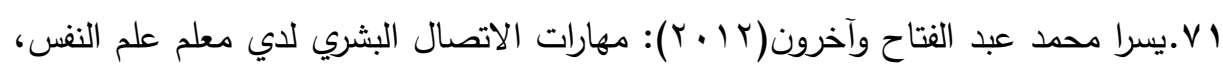

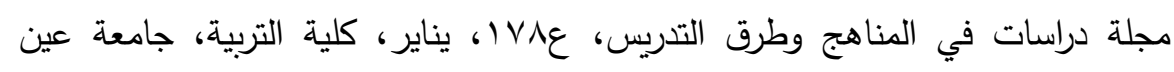
شمس.

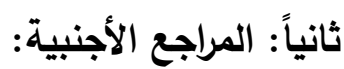

1) Ackerman, D. J. (2003).State's Efforts in Improving the Qualifications of Early Care and Education Teachers: National Institute for Early Educati on Research.

2) Andrews Jane and Higson Helen (2010): Graduate Employability, Soft Skills, Versus, Hard, Business Knowledge.

3) Barbara, dona,(2009): Improving Teachers Competency Based Training Program for Beginning The Year, Vol (78), No (22), P256.

4) Bettina Lankard Broun (2002) : Professional Development for career educators ,Eric clearing house on adult career and vocational education ,U.S.A . 


\section{أ.م.د/ سعيد عبد المعز على موسي}

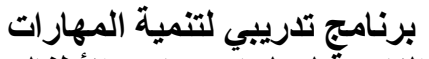

الناعمة لمعلمات رياض لثرية الأطفار

5) Clement, $M$ and Vandenberghe, $R$ (1997): Teacher Professional Development, a solitary on collegial adventure, paper presented at the annual meeting of the American educational research association, Chicago march 24-28.

6) Coscia, Steve (2013): Balancing Technical and Soft Skills, Contractor Magazine, Oct.2013, Vol. 60 Issue 10, p42.

7) Dorothy Bed ford, Jackson Coleen (2008): New Partnership for Learning Teacher Perspective on Their Developing professional Relationship with Teaching Assistants in England, journal of in-Service Education, Vol. 34, Issue. 1, March.

8) Ellis. A. \& Crawford, T (2000): Making intimate connection, guidelines for great relationships and better communication. New York, Impact Publishers.

9) Herzenberg, S., Price, M., \& Bradley, D. (2005).Declining Qualifications of early chidhood educators threatens nation'sfuture: U.S. Must Raise T eacher Standards to Help Children Succeed in School and In Life

10) Investopedia. (2014): Hard skills. Retrieved from http://www.investopedia.com/terms/h/hard-skills.asp.

11) Kenan (2018): WWW. Kenanaonline.com

12) Kevin Jones and Others (1999): Professional Development in response to problem behaviors in primary and special school in Singapore, Journal of in service education, Vol.2, No.1.

13) Lazarus, Arthur (2013): The importance of Soft Skills for Jop Success, Physician Executive, Sep/oct 2013, Vol. 39 Issue 5, p40.

14) Melinda Bonsall (1999): Inclusion of Special Education Students Using the Success for all programs, University of delawore.
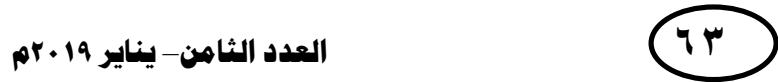
15) Rao M.S., (2012): Step by Step to soft skills training, Human Resource, management students through soft skills, Industrial and Commercial Training, Vol. 46 lssue 1pp. 42-48.

16) Robles, Marcel (2012): Executive Perceptions of the Top 10 Soft Skills Needed in Today's Workplace, Business Communication Quarterly, v75 n4 p453-465 Dec 2012.

17) Rowe, Alan J., and Mason, Richard (2003): Managing with Style, San Francisco, CA: Jossey Bass.

18) Schulz., Bernd (2008): The Importance of Soft Skills: Education beyond Academic Knowledge.

19) Siti Hamidah (2015): Department Food and Fashion Education Yogyakarta State University, Yogyakarta, Indonesia the 3rd UPI International Conference on Technical and Vocational Education and Training (TVET) Humanistic Soft Skills Learning for Generating Professional Teacher Performance.

20) Vasudevan, Lalanthika, Tirumala, Ashwin Pallikarana (2015): Effect of Computers on Creativity, Georgia Institute of Technology.

21) Vaughn, Sharon and Meaghan, Edmonds,(2006):Reading Comprehention For Older, ioural of intervention in Scool and Clinic, Vol .14, No.3, pp.131-137.

22) Waleed Twfik (2009): WWW. Bedayaonline.org.

23) White, Martha (2010): The Real Reason New College Grads Can't Get Hired, Research in Higher Education, Jun2012, Vol. 53 lssue 4, p383. 